NOTICE: this is the author's version of a work that was accepted for publication in Lithos. Changes resulting from the publishing process, such as peer review, editing, corrections, structural formatting, and other quality control mechanisms may not be reflected in this document. Changes may have been made to this work since it was submitted for publication. A definitive version was subsequently published in Lithos [119, 3-4, 2010] DOI 10.1016/j.lithos.2010.07.010 


\section{Geochronology and geochemistry of Late Paleozoic magmatic rocks in the Lamasu-Dabate area, northwestern Tianshan (west China): evidence for a tectonic transition from arc to post-collisional setting}

Gong-Jian Tang ${ }^{\mathrm{a}, \mathrm{b}}$, Qiang Wang ${ }^{\mathrm{a} *, \mathrm{c}}$, Derek A. Wyman ${ }^{\mathrm{d}}$, Min Sun ${ }^{\mathrm{e}}$, Zheng-Xiang Li ${ }^{\mathrm{c}}$, Zhen-Hua Zhao ${ }^{\text {a }}$, Wei-Dong Sun ${ }^{\mathrm{a}}$, Xiao-Hui Jia ${ }^{\mathrm{a}, \mathrm{b}}$, Zi-Qi Jiang ${ }^{\mathrm{a}, \mathrm{b}}$

${ }^{a}$ Key Laboratory of Isotope Geochronology and Geochemistry, Guangzhou Institute of Geochemistry, Chinese Academy of Sciences, Guangzhou 510640, P. R. China

${ }^{\mathrm{b}}$ Graduate University of Chinese Academy of Sciences, Beijing 100049, China

${ }^{\mathrm{c}}$ The Institute for Geoscience Research (TIGeR), Department of Applied Geology, Curtin University of Technology, GPO Box U1987, Perth, WA 6845, Australia

${ }^{d}$ School of Geosciences, Division of Geology and Geophysics, The University of Sydney, NSW 2006, Australia

${ }^{\mathrm{e}}$ Department of Earth Sciences, The University of Hong Kong, China

*Corresponding author

E-mail address: wqiang@gig.ac.cn (Q. Wang) 


\section{Abstract}

2 Voluminous Late Paleozoic igneous rocks and associated $\mathrm{Cu}-\mathrm{Au}-\mathrm{Mo}$ deposits occur in

3 the northwestern Tianshan district, Xinjiang, west China. However, the tectonic setting

4 and petrogenesis of these rocks remain controversial. This paper reports zircon U-Pb and

$5 \mathrm{Hf}$ isotopic data, major and trace elements, and $\mathrm{Sr}-\mathrm{Nd}-\mathrm{Pb}$ isotopic data for the intrusive

6 rocks and minor dacites in the Lamasu-Dabate area of northwestern Tianshan adjacent to

7 the $\mathrm{Cu}-\mathrm{Au}-\mathrm{Mo}$ deposits. LA-ICPMS U-Pb zircon analyses suggest that the Lamasu

8 porphyries were formed at $366 \pm 3 \mathrm{Ma}$ and contain 907-738 Ma inherited zircons, the

9 Dabate dacites were formed at $316 \pm 4 \mathrm{Ma}$, and granite porphyries were formed at $289 \pm$

103 Ma with $\sim 319$ Ma inherited zircons. The Lamasu porphyries consist of plagioclase

11 granite and granodiorite, and are geochemically similar to adakites, e.g., having high

$12 \mathrm{Al}_{2} \mathrm{O}_{3}$ (14.54-19.75 wt.\%) and $\mathrm{Sr}$ (308-641 ppm) and low Y (7.84-16.9 ppm) contents,

13 with fractionated rare earth element (REE) patterns and slightly positive $\mathrm{Sr}$ anomalies.

14 However, they have variable initial ratios of ${ }^{87} \mathrm{Sr}{ }^{86} \mathrm{Sr}(0.7072-0.7076)$ and ${ }^{206} \mathrm{~Pb} /{ }^{204} \mathrm{~Pb}$

15 (18.139-18.450), and variable $\varepsilon_{\mathrm{Nd}}(\mathrm{t})(-5.6$ to -0.8$)$ and positive $\varepsilon_{\mathrm{Hf}}(\mathrm{t})(+1.4$ to +10.6$)$

16 values. They also have variable $\mathrm{Mg}^{\#}\left(100 \times \mathrm{Mg}^{2+} /\left(\mathrm{Mg}^{2+}+\mathrm{Fe}^{2+}\right)\right)(41-73)$ and low $\mathrm{Th}$

17 (3.13-8.09) and $\mathrm{Th} / \mathrm{Ce}(0.14-0.28)$ values. We suggest that the Lamasu adakitic magmas

18 were generated through partial melting of southward subducted Junggar oceanic crust,

19 with subsequent melt-mantle interaction and assimilation of basement rocks. The Dabate

20 dacites show typical arc-like geochemical characteristics (e.g., enrichment of large ion

21 lithophile elements (LILE) and strong negative anomalies of $\mathrm{Ta}, \mathrm{Nb}, \mathrm{P}$ and $\mathrm{Ti}$ ), with 22 variable $\varepsilon_{\mathrm{Nd}}(\mathrm{t})(+0.1$ to +3.3$)$. They were probably generated by melting of juvenile 23 basaltic lower crust as a result of magma underplating. The Dabate granite porphyries are 24 geochemically similar to $\mathrm{A}_{2}$-type granites, e.g., high $\mathrm{SiO}_{2}$ (75.6-77.6 wt.\%) and alkalis $25 \quad\left(\mathrm{Na}_{2} \mathrm{O}+\mathrm{K}_{2} \mathrm{O}=8.27-8.70\right.$ wt.\%), low $\mathrm{CaO}\left(0.28-0.34\right.$ wt.\%) and $\mathrm{Mg}^{\#}$ (2-10), and obvious 26 negative $\mathrm{Eu}, \mathrm{Ba}$ and $\mathrm{Sr}$ anomalies. They have variable values of $\varepsilon_{\mathrm{Nd}}(\mathrm{t})(-1.7$ to 0$)$ and ${ }^{206} \mathrm{~Pb}^{204} \mathrm{~Pb}_{\mathrm{i}}(18.567-18.721)$ and zircon $\varepsilon_{\mathrm{Hf}}(\mathrm{t})(+0.5$ to +11.1$)$. The Dabate A-type

28 granite porphyries contain Late Carboniferous residual zircon cores, suggesting that their 29 source rock possibly contained Carboniferous arc igneous rocks. Taking into account all 30 available data from Late Paleozoic magmatic rocks and $\mathrm{Cu}-\mathrm{Mo}-\mathrm{Au}$ mineralization in the 31 northern Tianshan district, we suggest that the Dabate-Lamasu area was a continental arc 
32 during the Late Devonian-Carboniferous but had entered a post-collisional stage by the

33 Early-Permian $(\sim 290 \mathrm{Ma})$.

35 Key words: Adakite; A-type granite; arc; post-collisional; Xinjiang; Central Asian

36 Orogenic Belt

\section{1. Introduction}

39 Recognizing tectonic transitions from convergent margins to post-collision settings is an

40 interesting and an important challenge for geodynamic studies (e.g., Liégeois et al., 1998;

41 Ma et al., 1998; Barbarin, 1999; Chung et al., 2005; Whalen et al., 2006; Guo et al.,

42 2007). One common approach is to use changes in the characteristics and types of

43 magmatic rocks to establish the change in tectonic regimes (e.g., Barbarin, 1999; Chung

44 et al., 2005). For instance, adakites are often considered to have been generated in arc

45 settings (e.g., Defant and Drummond, 1990; Martin et al., 2005), whereas A-type granites

46 are commonly linked to rift or post-collisional settings (Eby, 1990, 1992; Whalen et al.,

47 1987) or a mildly extensional back-arc setting inboard of the continental margin arc

48 (Rivers and Corrigan, 2000). Such interpretations are not always straightforward.

50 The northwestern Tianshan Orogenic Belt (NTOB) is characterized by widespread 51 igneous rocks consisting predominantly of Late Paleozoic granites, intermediate volcanic 52 rocks and minor mafic intrusions (Fig. 1). These igneous rocks have attracted much 53 attention because they are often associated with $\mathrm{Cu}-\mathrm{Au}-\mathrm{Mo}$ mineralization. However, the 54 tectonic setting for the magmatism is still a matter of debate. Two types of models have 55 been proposed in the last decade. Some researchers suggested an extensional setting for 56 the Late Paleozoic (e.g., Carboniferous-Permian) igneous rocks, such as an 57 intra-continental rift (Xia et al., 2004a), a post-collisional environment (Wang and Xu, 58 2006; Han et al., 2010) or a mantle plume (Xia et al., 2004b; Zhou et al., 2004; Pirajno et 59 al., 2008). Conversely, others suggested that the Late Paleozoic tectonic setting of the 60 NTOB was mainly related to subduction of the Junggar plate beneath the Yili-Central 61 Tianshan plate (YCTP) (Gao et al., 1998; Liu and Fei, 2006; Wang et al., 2007c; Windley 62 et al., 1990; Xiao et al., 2008, 2009, 2004; Zhou et al., 2004;). Proponents of the latter 
63 model also disagree on the timing and evolution of the NTOB, with the proposed timing

64 for the final closure of the Junggar Ocean ranging from end of the Early Carboniferous

65 (Gao et al., 1998; Geng et al., 2009; Yin et al., 2010), the end of the Late Carboniferous

66 (e.g., Allen et al., 1993; Carroll et al., 1995; Coleman, 1989; Wang et al., 2006, 2007c;

67 Han et al., 2010), or the Late Permian (Xiao et al., 2008).

69 There are numerous porphyry copper and epithermal gold deposits in the Tianshan

70 district (Seltmann and Porter, 20005; Yakubchuk, 2004), e.g., the Tuwu-Yandong

71 porphyry copper-gold deposit (4.7 Mt Cu and $19 \mathrm{t} \mathrm{Au}$; Zhang et al., 2006a) and the Axi

72 (50 t Au) (Zhai et al., 2009) and Jinxi-Yelmand (60 t Au) epithermal gold deposits (Xiao

73 et al., 2005). All of these deposits were formed during the Late Devonian-Late

74 Carboniferous interval and were associated with contemporary igneous rocks (e.g., Qin et

75 al., 2002; Wang et al., 2006c; Zhang et al., 2006a). Although a number of detailed studies

76 have been conducted on the geology and timing of some of the deposits (Zhang et al.,

77 2006b, 2008b, 2008c), relationships between ore genesis and magmatism, and tectonic

78 settings remain unclear.

80 In this paper we report zircon U-Pb ages, and geochemical, $\mathrm{Sr}-\mathrm{Nd}-\mathrm{Pb}$ and zircon $\mathrm{Hf}$

81 isotopic compositions of the Lamasu and Dabate magmatic rocks in the NTOB. The 82 studied rocks include adakitic granitoids, dacites with 'arc-like geochemical

83 characteristics', and A-type granites formed during the Late Devonian and the Early

84 Permian, respectively. Based on these new data and previously published geological,

85 geochronological, and geochemical data for porphyries in other NTOB $\mathrm{Cu}-\mathrm{Au}$ deposits,

86 we examine the petrogenesis of the Lamasu and Dabate magmatic rocks and the

87 relationship between ore genesis and Late Paleozoic magmatism and tectonics in the

88 region.

89

\section{2. Geologic background}

91 The NTOB is the north branch of the Tianshan Orogenic Belt (Fig. 1). It is located 92 between the Junggar plate to the north and the Yili-Central Tianshan plate (YCTP) to the 93 south (Fig. 1). It is widely accepted that the NTOB represents a Late Paleozoic 
94 continental arc developed along the northern margin of the YCTP due to the subduction

95 of the Paleo-Junggar Ocean (e.g., Gao et al., 1998; Wang et al., 2007a, 2006c; Xiao et al., 96 2008).

98 The basement metamorphic rocks of the NTOB, consisting of Precambrian (821-798 Ma)

99 granitic gneisses and amphibolites of the Wenquan Formation crop out south of the

100 Sayram Lake (Hu et al., 2000) (Fig. 1). Cambrian-Ordovician rocks mainly occur in the

101 vicinity south-east of the Sayram Lake and consist of cherts, siltstones and carbonates.

102 Silurian rocks are distributed along the southern side of the northern Tianshan Fault (NTF)

103 and include flysches, limestones and intercalated calc-alkaline volcanic and

104 volcano-sedimentary rocks (Wang et al., 2007a) (Fig. 1). Devonian rocks consist of

105 conglomerates, sandstones, siltstones, basalts and andesitic porphyries, and mainly crop

106 out in the Alataw and Bayingou area. Carboniferous strata are widespread in the NTOB

107 and consist of limestone, sandstones, shale and volcanic rocks. Permian terrestrial

108 sandstones and conglomerates in the Alataw and Sayram Lake area unconformably

109 overlie all older rocks.

111 Late Devonian to Early Permian granitic and volcanic rocks occur along the NTOB with

112 a west-northwest trend and minor Early Paleozoic granites are found in the Wenquan area

113 (Fig. 1a, b). The Devonian to Carboniferous volcanic rocks mainly comprise calc-alkalic

114 basalts, andesites and rhyolite flows, and tuffs (Xinjiang Bureau of Geology and Mineral

115 Resources (XBGMR), 1993). Some Permian intrusive rocks also occur in the NTOB

116 (XBGMR, 1993).

118 The NTOB hosts a large number of porphyry copper (molybdenum) and epithermal gold 119 deposits (Li et al., 2006; Zhang et al., 2006b). The widespread porphyry copper deposits 120 are associated with some of the Devonian to Late Carboniferous igneous rocks in the 121 Lamasu-Dabate and Lailisigao'er areas (Fig. 1a, b). However, epithermal gold deposits 122 mainly occur in the Axi area and are associated with Early Carboniferous andesites (Fig. $1231 \mathrm{a}, \mathrm{b})$. 
125 The Lamasu-Dabate area, northwest of the Sayram Lake, is located in the west part of the 126 NTOB (Fig. 1a, b). Devonian to Carboniferous volcanic-sedimentary rocks are abundant. 127 The Precambrian rocks exposed west of the Sayram Lake consist of grey limestone, 128 mudstones and clastic rocks of the Neoproterozoic Kusongmuqieke Formation (XBGMR, 129 1993). The south Lamasu fault crops around $2 \mathrm{~km}$ to the south of the Lamasu and can be 130 traced for more than $20 \mathrm{~km}$ (Fig. 1b).

132 The Lamasu $\mathrm{Cu}$ deposit is located about $3 \mathrm{~km}$ west of the Sayram Lake within variably

133 recrystallised limestone of the Neoproterozoic Kusongmuqieke Formation, intruded by

134 Late Paleozoic porphyry stocks (Fig. 1c). The ore-related porphyries consist of 135 plagioclase granites, granodiorites and dioritic porphyries and diabases (Fig. 1c). The 136 ore-bodies are mainly distributed along the contact zones between the porphyritic 137 intrusions and limestone but some occur in fractures within the limestone. Numerous 138 diabase dikes, typically $100 \mathrm{~m}$ long and 1-6 m wide, occur in the ore bodies (Fig. 1c) 139 (Zhang et al., 2008c).

141 The Dabate Cu-Mo deposit is located about $20 \mathrm{~km}$ northeast of Sayram Lake within 142 tuffaceous breccia and lava of the Devonian Tuosikuertawu Formation (Fig. 1d). 143 Copper-Mo mineralization occurs mainly in dacites and the fracture zone between dacites 144 and rhyolitic tuff breccia in the southwest of the Dabate area, rather than in the Dabate 145 granites (Fig. 1d). A Re-Os age of $301 \pm 20$ Ma was reported for molybdenite in the 146 Dabate deposit (Zhang et al., 2006c).

\section{Petrography}

149 There are a large number of intermediate-felsic intrusive bodies and dykes intruding the

150 Neoproterozoic Kusongmuqieke Formation in the Lamasu area, which mainly consist of 151 plagioclase granite and granodiorite. These rocks consist mainly of medium-fine to 152 coarse-grained plagioclase, and minor quartz, biotite, and hornblende phenocrysts. 153 Plagioclase crystals exhibit zonal textures and most exhibit some degree of sericitization. 154 Quartz crystals commonly display rounded shapes due to resorption. Some altered 155 porphyry samples contain biotite crystals that have been altered to chlorite, particularly 
156 along cleavages and grain boundaries. The plagioclase granite porphyries contain over 50

157 volume percent of phenocrysts whereas the granodiorite porphyry consists of less than 50

158 volume percent phenocrysts. In addition, the dominant phenocrysts for the plagioclase

159 granite porphyry are plagioclase, hornblende, and biotite with minor quartz, but in

160 granodiorite porphyry plagioclase, biotite and quartz phenocrysts are common.

161

162 Dacites in the Dabate area also exhibit a porphyritic texture with phenocrysts of 163 plagioclase (10-15 vol. \%), quartz (2-3 vol. \%), hornblende (2-5 vol. \%), and biotite (1-2 164 vol. \%). Their groundmass is mainly composed of plagioclase (45-50 Vol. \%) and quartz 165 (25-30 vol. \%). Plagioclase phenocrysts are euhedral, exhibiting zonal textures and 166 variable degrees of sericitization. Quartz displays rounded shapes caused by resorption. 167 Hornblende occurs as variably altered euhedral 50-200 $\mu \mathrm{m}$ phenocrysts, and 100-200 $\mu \mathrm{m}$ 168 subhedral brown biotite phenocrysts also present.

170 The granite porphyries in the Dabate area typically contain coarse-grained $(3-7 \mathrm{~mm})$ 171 phenocrysts of alkali-feldspar and quartz with subordinate biotite and plagioclase feldspar.

172 Alkali-feldspar phenocrysts are generally subhedral or euhedral and some occur in 173 polysyntheti or carlsbad-albite compound twins. Some quartz crystals show resorption 174 shapes. The rims of some plagioclase phenocrysts exhibit sericitization. Biotite 175 phenocrysts are generally platy with brownish color. The groundmasses mainly consist of 176 quartz and potassium feldspar.

\section{4. Results}

179 Analytical methods, U-Pb age data, representative whole-rock geochemical analyses, $180 \mathrm{Sr}-\mathrm{Nd}-\mathrm{Pb}$ isotope data and in situ $\mathrm{Hf}$ isotopic analyses of zircons from the Lamasu and 181 Dabate magmatic rocks are listed in Appendices 1-5, respectively. The least altered 182 samples were selected for geochemical and isotopic analyses. 
185 To determine the emplacement ages of the porphyries, three samples were chosen for

186 LA-ICPMS zircon U-Pb dating from the Lamasu and Dabate deposits. The zircon grains

187 from the three samples have size ranges of 50-180 $\mu \mathrm{m}$ and $40-130 \mu \mathrm{m}$ and length/width

188 ratios of 2:1-3:1 and 1:1-3:1, respectively. Cathodoluminescence images of zircon grains

189 used for LA-ICP-MS analysis show micro-scale oscillatory zoning with or without a

190 homogeneous core (Fig. 2), and exhibit high Th/U ratios (0.12-1.07 for Lamasu samples

191 and $0.45-1.32$ and $0.28-1.01$ for the Dabate dacite and granite samples, respectively),

192 suggesting magmatic origins (Belousova et al., 2002). Concordia diagrams and

193 representative CL images of analyzed zircons are shown in Fig. 2.

195 The Lamasu granodiorite porphyry sample (06XJ017) (Fig. 1, 8058'43"N, 4440'342"E):

196 seventeen analyses of the youngest age population have indistinguishable $\mathrm{U}-\mathrm{Pb}$ isotopic

197 compositions, which correspond to a weighted mean ${ }^{206} \mathrm{~Pb} /{ }^{238} \mathrm{U}$ age of $366 \pm 3 \mathrm{Ma}(2 \sigma$;

198 MSWD $=0.28$ ) (Fig. 2a). This age is interpreted as the best estimate of the time of

199 crystallization of the Lamasu porphyries. Some zircons have core-rim structure and four 200 analyses of zircon cores gave ${ }^{206} \mathrm{~Pb} /{ }^{238} \mathrm{U}$ ages ranging between $738 \mathrm{Ma}$ and $907 \mathrm{Ma}$,

201 which either represent inheritance from the magma source or xenocrysts captured from

202 Neoproterozoic country rocks. The remaining three analyses gave ${ }^{206} \mathrm{~Pb} /{ }^{238} \mathrm{U}$ ages ranging

203 between $400 \pm 4 \mathrm{Ma}$ and $405 \pm 4 \mathrm{Ma}$ for the zircon rims with a weighted mean ${ }^{206} \mathrm{~Pb} /{ }^{238} \mathrm{U}$

204 age of $402 \pm 5 \mathrm{Ma}$. The relatively old ages suggest that these zircons are inherited from

205 the magma source or xenocrysts captured from country rocks.

207 The Dabate dacite sample (06XJ04) (Fig. 1, 81 ${ }^{\circ} 25^{\prime} 25^{\prime \prime N}, 44^{\circ} 44^{\prime} 30^{\prime \prime E}$ ): eight of twelve 208 analyses have ${ }^{206} \mathrm{~Pb} /{ }^{238} \mathrm{U}$ ages ranging from $310 \pm 13 \mathrm{Ma}$ to $325 \pm 9 \mathrm{Ma}$, which 209 correspond to a single age population with a weighted mean ${ }^{206} \mathrm{~Pb} /{ }^{238} \mathrm{U}$ age of $316 \pm 4 \mathrm{Ma}$ $210(2 \sigma)(\mathrm{MSWD}=0.33)($ Fig. $2 b)$. This age is considered to record the emplacement age of 211 this intrusion. Some zircons also have core-rim structure and two analyses of zircon gave $212{ }^{206} \mathrm{~Pb} /{ }^{238} \mathrm{U}$ ages ranging between $774 \mathrm{Ma}$ and $971 \mathrm{Ma}$, and the remaining two analyses of 213 zircon gave ${ }^{206} \mathrm{~Pb} /{ }^{238} \mathrm{U}$ ages about $420 \mathrm{Ma}$. These zircons may represent inheritance from 214 the magma source or xenocrysts captured from country rocks. 
216 The Dabate granite porphyry sample (06XJ013) (Fig. 1, 81 ${ }^{\circ} 25^{\prime} 52^{\prime \prime} \mathrm{N}, 44^{\circ} 44^{\prime} 45^{\prime \prime} \mathrm{E}$ ):

217 eighteen of twenty-four analyzes have ${ }^{206} \mathrm{~Pb} /{ }^{238} \mathrm{U}$ ages ranging from $278 \pm 3$ Ma to $294 \pm$

$2183 \mathrm{Ma}$, which correspond to a single age population with a weighted mean ${ }^{206} \mathrm{~Pb} /{ }^{238} \mathrm{U}$ age

219 of $289 \pm 3 \mathrm{Ma}(2 \sigma)(\mathrm{MSWD}=2.3)$, which is taken here as the emplacement age of this

220 intrusion. The remaining four analyses for cores and rounded zircons yielded a weighted

221 mean ${ }^{206} \mathrm{~Pb} /{ }^{238} \mathrm{U}$ age of $319 \pm 6 \mathrm{Ma}$ (Fig. 2c), which is interpreted to signify trapped

222 grains from Carboniferous volcanic rocks.

223

224 4.2 Whole-rock geochemistry

225 4.2.1 The Lamasu intrusive rocks

226 The compositions of the Lamasu intrusive rocks range from gabbroic-dioritic to granitic, 227 but are mainly granodioritic to granitic (Fig. 3a) and with sub-alkaline affinities (Fig. 3b).

228 They are calc-alkaline and plot in the fields of medium- and high-K calc-alkaline series

229 igneous rocks (Fig. 3c and d). The Lamasu intrusive rocks can be subdivided into three

230 groups based on their petrography: plagioclase granite porphyries and granodiorite

231 porphyries (group 1); diorite porphyries (group 2) and diabases (group 3).

232 Chondrite-normalized REE patterns (Fig. 4a) for the three groups are approximately

233 parallel, and their light and heavy rare earth elements (LREE and HREE) are enriched

234 and depleted, respectively. The plagioclase granite and granodiorite porphyries have 235 consistent geochemical compositions, with slightly negative Eu anomalies $(\mathrm{Eu} / \mathrm{Eu}$ *

$236\left(\mathrm{Eu}_{\mathrm{N}} /\left[(1 / 2) \times\left(\mathrm{Sm}_{\mathrm{N}}+\mathrm{Gd}_{\mathrm{N}}\right)\right]\right.$, where subscript $\mathrm{N}$ denotes chondrite normalized $\left.)=0.52-0.74\right)$

237 (Fig. 4a; Table 1). Primitive mantle-normalized trace element patterns (Fig. 4b) show that

238 the plagioclase granite and granodiorite porphyries have $\mathrm{Nb}$, $\mathrm{Ta}$ and $\mathrm{Ti}$ depletions. The

239 diorite porphyries display distinct negative $\mathrm{Eu}$ anomalies $\left(\mathrm{Eu} / \mathrm{Eu}^{*}=0.50-0.52\right)$ and

240 higher REE contents, whereas, the diabase porphyry has a positive Eu anomaly (Eu/Eu*

$241=1.22$ ) (Fig. 4a). The diorite porphyries have negative $\mathrm{Sr}$ anomalies and no Ti anomalies,

242 and the diabase has negligible $\mathrm{Nb}$, Ta anomalies, a positive Ti anomaly and a slight

243 depletion of large ion lithophile elements (LILE) (Fig. 4b).

245 The Lamasu plagioclase granite and granodiorite porphyries exhibit adakite geochemical 246 characteristics (Defant and Drummond, 1990; Kay, 1978; Martin et al., 2005). These 
247 samples are characterized by fractionated rare earth element $(\mathrm{REE})$ patterns $\left(\mathrm{La} / \mathrm{Yb}_{\mathrm{N}}=\right.$ 248 4.6-10.6) (Fig. 4a, 5a; Table 1), and slightly positive Sr anomalies (Fig. 4b), though they 249 have slightly negative Eu anomalies (Fig. 4a), with high $\mathrm{Al}_{2} \mathrm{O}_{3}$ (14.54-19.75 wt.\%), Sr 250 (308-641 ppm) and lower Y (7.84-16.9 ppm) contents (Table 1). On the Sr/Y-Y 251 discrimination diagrams of Defant and Drummond (1990) (not shown), they plot in the 252 adakite field, and they are similar to Tuwu-Yandong adakitic porphyries, though with 253 slightly higher $\mathrm{Yb}_{\mathrm{N}}$ (Fig. 5a). The diorite porphyries (06XJ19-1 and 06XJ19-2) do not 254 show adakitic geochemical characteristics and have relatively lower Sr contents (131-257 $255 \mathrm{ppm}$ ) and $\mathrm{Sr} / \mathrm{Y}$ ratios (6-11) (Appendix 3).

257 4.2.2 The Dabate dacites

258 The Dabate dacite samples have consistent geochemical signatures (Fig. 3). They have $259 \mathrm{SiO}_{2}$ contents of 62.12 to 64.38 wt.\% (Table 1), and display sub-alkaline affinities on a $260 \mathrm{Nb} / \mathrm{Y}-\mathrm{Zr}$ /Ti diagram (Fig. 3b) and calc-alkaline affinities on the AFM plot (Fig. 3c). The 261 dacite samples fall in the field of medium and high $\mathrm{K}$ calc-alkaline igneous rocks (Fig. $2623 \mathrm{~d})$. They are metaluminous or peraluminous with $\mathrm{A} / \mathrm{CNK}(\operatorname{molar}[\mathrm{Al} /(\mathrm{Ca}+\mathrm{Na}+\mathrm{K})]=$ 2630.96 - 1.22), display LREE enrichment and HREE depletion $\left((\mathrm{La} / \mathrm{Yb})_{\mathrm{N}}=3.3-6.4\right)$ with 264 slightly negative Eu anomalies $\left(\mathrm{Eu} / \mathrm{Eu}^{*}=0.55-0.83\right)$ (Fig. 4c; Table 1). These rocks are 265 characterized by strong negative anomalies of $\mathrm{Ta}, \mathrm{Nb}, \mathrm{P}$ and $\mathrm{Ti}$, and enrichment in LILE 266 in primitive mantle-normalized diagram, suggesting a typical arc-like nature (Tatsumi 267 and Eggins, 1995) (Fig. 4d). Overall, these rocks show characteristics similar to others 268 previously attributed to Late Carboniferous arc magmatism on the north margin of the 269 YCTP (Wang et al., 2007a, 2007c).

271 4.2.3 The Dabate granite porphyries

272 The Dabate granite porphyries have high $\mathrm{SiO}_{2}$ (73.97-77.61 wt.\%) and $\mathrm{K}_{2} \mathrm{O}$ (4.92-8.08 $273 \mathrm{wt} \%$ ) contents, high $\mathrm{K}_{2} \mathrm{O} / \mathrm{Na}_{2} \mathrm{O}$ ratios (1.2-5.8) (Table 1; Appendix 3) and low $\mathrm{Al}_{2} \mathrm{O}_{3}$ 274 contents (12.0-13.1 wt.\%), and exhibit weakly metaluminous to peraluminous 275 characteristics $(\mathrm{A} / \mathrm{CNK}=0.93-1.55)$. They are low in $\mathrm{CaO}, \mathrm{MgO}$ and $\mathrm{P}_{2} \mathrm{O}_{5}$ and plot in 276 the field of high-K calc-alkaline igneous rocks (Fig. 3d). The porphyries also show 277 relatively flat normalized REE patterns $\left.(\mathrm{La} / \mathrm{Yb})_{\mathrm{N}}=1.6-5.2\right)$ with pronounced negative Eu 
anomalies $\left(\mathrm{Eu} / \mathrm{Eu}^{*}=0.09-0.19\right)$ (Fig. 4e; Table 1). They have high concentrations of high field strength elements HFSE (Zr, Hf, Nb and Ta) and LILE (Th and U) (Fig. 4f)

280 and strong negative $\mathrm{Sr}, \mathrm{Ba}$ and $\mathrm{Ti}$ anomalies.

The Dabate granite porphyries in the NTOB are geochemically similar to typical A-type granites (Eby, 1990, 1992; Frost et al., 2001; Whalen et al., 1987). They have high total alkalis contents $\left(\mathrm{K}_{2} \mathrm{O}+\mathrm{Na}_{2} \mathrm{O}=8.26-10.10\right.$ wt.\%) and $\mathrm{FeO}_{\text {total }}\left(\mathrm{FeO}_{\text {total }}+\mathrm{MgO}\right)$ ratios (0.77-0.99). The extremely low $\mathrm{P}_{2} \mathrm{O}_{5}$ contents and the absence of any phosphate mineral 286 also suggest that the Dabate granitic porphyries are similar to A-type granites rather than 287 S-type leuogranites (Bonin, 2007; King et al., 1997). The trace element composition of 288 the Dabate granitic porphyries also exhibits A-type granite geochemical characteristics 289 (Whalen et al., 1987; $\mathrm{Wu}$ et al., 2002), e.g., high $10,000 \times \mathrm{Ga} / \mathrm{Al}$ ratios (3.7-4.2, with an 290 average value of 3.7 (Appendix 3), enrichment in HFSE ( $\mathrm{Nb}, \mathrm{Y}$ and $\mathrm{Zr}$ ), no $\mathrm{Nb}-\mathrm{Ta}$ 291 anomalies, and clear depletions in $\mathrm{Ba}, \mathrm{Sr}, \mathrm{Eu}$ and $\mathrm{Ti}$ (Fig. 4f). They also have $\mathrm{Nb} / \mathrm{Ta}$ 292 (10-13) and Zr/Hf (22-28) ratios similar to typical A-type granite (Eby, 1992; King et al., 293 1997). They plot in the A-type granite field on discrimination diagrams involving $\mathrm{Ga} / \mathrm{Al}$ 294 (Fig. 6) and in the within-plate field on Y-Nb and Ta-Yb plots (Fig. 7a-b). They also have 295 high $\mathrm{Yb} / \mathrm{Ta}(1.5-3.9)$ and $\mathrm{Y} / \mathrm{Nb}(1.43-3.51)$ ratios, suggesting that they can be further classified as $\mathrm{A}_{2}$-type granites (Eby,1992) (Fig. 7c-d).

\subsection{Sr-Nd-Pb isotopic geochemistry}

299 Initial ${ }^{87} \mathrm{Sr} /{ }^{86} \mathrm{Sr}$ ratios and $\varepsilon_{\mathrm{Nd}}(t)$ values were calculated using the new age data. Because 300 the Dabate granite porphyries have extremely high $\mathrm{Rb} / \mathrm{Sr}$ ratios, their calculated initial ${ }^{87} \mathrm{Sr} /{ }^{86} \mathrm{Sr}$ ratios are not meaningful (e.g., Wu et al., 2002). The Lamasu plagioclase 302 granites and granodiorite porphyries have initial ${ }^{87} \mathrm{Sr} /{ }^{86} \mathrm{Sr}$ ratios ranging from 0.7072 to 3030.7076 and negative $\varepsilon_{\mathrm{Nd}}(t)$ values ranging from -3.7 to -0.8 . One diabase sample has 304 lower initial ${ }^{87} \mathrm{Sr} /{ }^{86} \mathrm{Sr}$ ratio $(0.7059)$ and positive $\varepsilon_{\mathrm{Nd}}(t)$ value $(+3.4)$. A diorite porphyry 305 sample also has a positive $\varepsilon_{\mathrm{Nd}}(t)$ value of +1.4 (Appendix 4; Fig. 8a). The Dabate dacites 306 have variable $\varepsilon_{\mathrm{Nd}}(t)$ value ranging from +0.1 to +3.3 . The Dabate granite porphyries have 307 slightly higher $\varepsilon_{\mathrm{Nd}}(t)$ value (-1.7 to 0.0$)$ than those of the Lamasu plagioclase granites and 308 granodiorite porphyries (Fig. 8a). 
310 The Lamasu plagioclase granite and granodiorite porphyries and the Dabate granite

311 porphyries have radiogenic $\mathrm{Pb}$ isotopic compositions with ${ }^{206} \mathrm{~Pb} /{ }^{204} \mathrm{~Pb}_{\mathrm{i}}$ ranging from

312 15.538-15.581 and 15.635-15.717, respectively (Appendix 4; Fig. 8b). The Lamasu

313 diorite and diabase porphyries have ${ }^{206} \mathrm{~Pb} /{ }^{204} \mathrm{~Pb}_{\mathrm{i}}$ values of 18.046 and 17.909 , respectively

314 (Fig. 8b), and two Dabate granite porphyry samples have similar $\mathrm{Pb}$ isotopic

315 compositions with ${ }^{206} \mathrm{~Pb} /{ }^{204} \mathrm{~Pb}_{\mathrm{i}}$ and ${ }^{207} \mathrm{~Pb} /{ }^{204} \mathrm{~Pb}_{\mathrm{i}}$ values of $18.569-18.721$ and

316 15.714-15.717, respectively (Appendix 4; Fig. 8b)

318 4.4 Zircon Hf isotopic geochemistry

319 In situ Hf isotopic analyses of zircons from the Lamasu granodiorite porphyry and

320 Dabate granite porphyry samples are shown in Figures 8c and 9. Three groups of zircons

321 are recognized from the Lamasu granodiorite porphyry sample (06XJ17). The magmatic

322 zircons with 366 Ma crystallization ages (group 1) have variable Hf isotopic

323 compositions (Appendix 5; Fig. 9a), with ${ }^{176} \mathrm{Hf} /{ }^{177} \mathrm{Hf}$ ratios of $0.282594-0.282865, \varepsilon_{\mathrm{Hf}}(t)$

324 values of +1.4 to +10.6 and $T_{\mathrm{DM}}$ values of $0.58-0.95 \mathrm{Ga}$. The group 2 entrained zircons

$325(400-405 \mathrm{Ma})$ have ${ }^{176} \mathrm{Hf} /{ }^{177} \mathrm{Hf}$ ratios of $0.282574-0.282606, \varepsilon_{\mathrm{Hf}}(t)$ values of +0.8 to +1.7

326 and $T_{\mathrm{DM}}$ values of 0.93-0.96 Ga (Appendix 5; Fig. 9a). The inherited zircon cores

327 (738-907 Ma) (group 3) have variable $\mathrm{Hf}$ isotopic compositions, with ${ }^{176} \mathrm{Hf} /{ }^{177} \mathrm{Hf}$ ratios of $3280.282529-0.282779, \varepsilon_{\mathrm{Hf}}(t)$ values of -9.7 to -0.9 , and $T_{\mathrm{DM}}$ values of $1.04-1.39 \mathrm{Ga}$

329 (Appendix 5; Fig. 9a).

331 Magmatic zircons (group 1) from the Dabate granite porphyry sample (06XJ13) also have 332 variable $\mathrm{Hf}$ isotopic compositions with ${ }^{176} \mathrm{Hf} /{ }^{177} \mathrm{Hf}$ ratios of $0.282624-0.282883, \varepsilon_{\mathrm{Hf}}(t)$ 333 values of +0.5 to +8.3 and $T_{\mathrm{DM}}$ values of $0.6-0.9 \mathrm{Ga}$ (Appendix 5; Fig. 9b). However,

334 three xenocrystic zircons (group2, ca.319 Ma) from this sample have ${ }^{176} \mathrm{Hf} /{ }^{177} \mathrm{Hf}$ ratios of $3350.282694-0.282926, \varepsilon_{\mathrm{Hf}}(t)$ values of +3.0 to +11.1 and $T_{\mathrm{DM}}$ values of $0.49-0.81 \mathrm{Ga}$ 336 (Appendix 5; Fig. 9b).

\section{Discussion}


340 The available data clearly show three main magmatic episodes in the Late Paleozoic for 341 the NTOB (Fig. 10). The first episode occurred during the Late Devonian to the Early 342 Carboniferous (366-341 Ma). Typical examples include: (1) the 362-350 Ma

343 Lailisigao'er granodiorite porphyry and monzodioritic porphyritic plutons associated with 344 Cu-Mo deposits (Li et al., 2006; Zhang et al., 2009); (2) 345 Ma intrusive rocks 345 associated with copper mineralization located $1 \mathrm{~km}$ to the northwest of the Lailisigao'er 346 Cu-Mo deposits (Fig. 1); (3) the 352 Ma Guozigou granodiorite (Xu et al. 2006b); (4) 347 the $\sim 363$ Ma volcanic rocks of the Dahalajunshan formation in the Axi low-sulfidation 348 type epithermal gold deposit (Zhai et al. 2006; 2009); and (5) the 366 Ma Lamasu 349 plagioclase granite porphyry (this study), which formed in an arc setting. The second 350 episode of magmatism occurred during the Late Carboniferous (317-306 Ma). Typical 351 examples include: (1) the $\sim 316$ Ma Dabate dacite (Zhang et al., 2008b); (2) $317 \mathrm{Ma}$ 352 Kekesai granodiorite porphyry (Zhang et al., 2008a); (3) the $~ 308$ Ma Borohoro diorite 353 pluton (Zhu et al., 2006)); (3) the 310-306 Ma Alatawa adakites (Wang et al., 2007c).

354 This magmatic episode most probably occurred in an arc setting associated with the 355 southward subduction of the Junggar Ocean (Wang et al., 2007a, 2007c). The youngest 356 magmatism is of Early Permian age (294-280 Ma). The A-type Dabate granitic porphyry 357 (289 $\pm 3 \mathrm{Ma}$, this study) is typical of this magmatic episode. The high-K calc-alkaline 358 granites of the Borohoro area (Fig. 1) have a similar age (294-280 Ma) and have been 359 interpreted to have formed in a post-collisional setting (Wang et al., 2009).

361 In the study region, the three episodes of magmatism are represented by the $366 \pm 3 \mathrm{Ma}$ 362 Lamasu granodiorite porphyries (this study), the $316 \pm 4 \mathrm{Ma}$ (this study) and the $316 \pm 6$ 363 Ma Dabate dacite (Zhang et al., 2008b), and the Dabate A-type granites, respectively. 364 These three episodes of magmatic rocks possibly recorded the changes in tectonic 365 settings in the NTOB.

366

$367 \quad 5.2$ Petrogenesis

368 5.2.1 The Lamasu intrusive rocks

369 Except for slightly negative Eu anomalies, most samples of the Lamasu granites and 370 granodiorite porpyries exhibit geochemical characteristics of adakites. Adakites were 
originally considered to be generated by melting of subducted young and hot oceanic crust (Model A) (Defant and Drummond, 1990), based on a study of magnesian andesite from Adak Island in the Aleutians (Kay, 1978). They have been extensively studied because of their unusual compositions, tectonic settings and potential for $\mathrm{Cu}-\mathrm{Au}$ mineralization (e.g., Defant and Kepezhinskas, 2001; Martin et al., 2005; Mungall, 2002; Oyarzun et al., 2001; Reich et al., 2003; Wang et al., 2006b).

We suggest that the Lamasu adakitic magmas were most probably generated by partial melting of subducted oceanic crust based on both geological and geochemical evidence. First, there is growing evidence for a Devonian to Early Carboniferous arc setting in the northwestern Tianshan. Recently, some Carboniferous ophiolites have been identified in the area, e.g., the $344.0 \pm 3.4$ Ma Bayingou ophiolite in the northwestern Tianshan $(\mathrm{Xu}$ et al., 2006a). This ophiolite is only slightly younger than the Lamasu intrusive rocks. Devonian to Early Carboniferous arc-type granitoids and volcanic rocks are abundant in this region (Fig. 1). Many studies suggest that a Junggar oceanic crust subducted south beneath the YCTP, forming a Late Devonian to Early Carboniferous arc along the northern margin of the YCTP (Gao et al., 1998; Liu and Fei, 2006; Wang et al., 2007c; Windley et al., 1990; Xiao et al., 1991). Kröner et al. (2008) described Late Palaeozoic (407-369 Ma) granitoids in central Kazakhstan (the westward extension of northwestern Tianshan) and showed that they are the product of arc magmatism. The Lamasu intrusive rocks exhibit $\mathrm{Nb}$, $\mathrm{Ta}$ and $\mathrm{Ti}$ depletions and enrichment of mobile LILE, similar to arc-related magmatism (Tatsumi and Eggins, 1995) (Fig. 4b). On the $\mathrm{Y}-\mathrm{Nb}$ and $\mathrm{Yb}-\mathrm{Ta}$ tectonic discrimination diagram (Fig. 7a-b) (Pearce et al., 1984), all samples of the Late Devonian to Early Carboniferous porphyries in the Lamasu and Lailisigao'er areas plot in the volcanic arc field. These studies suggest that there was an active margin during the Devonian to Early Carboniferous in the study region and that the Lamasu adakitic rocks formed in an arc setting. Second, the Lamasu intrusive rocks are geochemically similar to slab-derived adakites. Although some samples of the Lamasu intrusive rocks have low $\mathrm{MgO}$ contents (Fig. 5c), most samples have high $\mathrm{Mg}^{\#}$ values (Fig. 5d), similar to those of typical subducted oceanic crust-derived adakite. In addition, they have very low Th contents (3.13-8.09 ppm) and low $\mathrm{Th} / \mathrm{Ce}$ ratios (0.14-0.28), indicating that their 
402 compositions are more consistent with Cenozoic adakite formed by slab melting in an arc 403 setting (Defant et al., 1992; Kay, 1978; Kay et al., 1993; Stern and Kilian, 1996; Moyen 404 and Stevens, 2006).

406 However, the Lamasu intrusive rocks show slightly negative Eu anomalies $\left(\mathrm{Eu} / \mathrm{Eu}^{*}=\right.$ $4070.52-0.74$ ) (Fig. 4a; Table 1), in contrast to typical subducted oceanic crust-derived 408 adakites that have negligible-positive Eu anomalies (Defant and Drummond, 1990). The 409 negative Eu anomalies of the Lamasu intrusive rocks may be caused by three processes:

410 (1) fractional crystallization of plagioclase; (2) residual plagioclase in the source; (3) 411 crustal contamination. On a plot of $\mathrm{Nb} / \mathrm{Ta}$ versus $\mathrm{Zr} / \mathrm{Sm}$ (Fig. 5b) the Lamasu intrusive 412 rocks fall in the field of hornblende eclogite melting rather than that of rutile eclogite. 413 This suggests that the Lamasu adakitic rocks were generated at shallower depths, and 414 thus minor plagioclases might be stable as residual phases. It may also be possible that 415 the $\mathrm{Nb} / \mathrm{Ta}$ fractionation occurs during dehydration of subducting slabs under thermal 416 gradients (Xiao et al., 2006; Ding et al., 2009; Liang et al., 2009). The depleted HREE 417 and Y (Fig. 4a-b) suggest that garnet was a major residual mineral in their source.

419 The Lamasu intrusive rocks have more variable and higher initial ${ }^{87} \mathrm{Sr} /{ }^{86} \mathrm{Sr}$ ratios, lower $420 \varepsilon N d(t)$ values and more variable $\mathrm{MgO}$ contents than slab-derived adakites (Fig. 8; 421 Appendix 4), but high $\mathrm{Mg}^{\#}$ similar to the latter (Fig. 5d). These characteristics may 422 reflect two-stage contamination: slab-derived melts were first contaminated by mantle 423 peridotite during ascent, increasing $\mathrm{MgO}, \mathrm{Mg}^{\#}$ and compatible elements contents (Fig. $4245 \mathrm{~d}$ ); followed by contamination by basement metamorphic rocks during passage through 425 the crust. This scenario is strongly supported by inherited zircons with northwestern 426 Tianshan Neoproterozoic basement crust ages (900 \pm 20 Ma; Fig. 2a) (Hu et al., 2000) in 427 the Lamasu adakites. The presence of Neoproterozoic zircon xenocrysts and their 428 negative $\varepsilon H f$ values strongly suggests that basement crustal contamination also played a 429 significant role in the formation of the Lamasu intrusive rocks. Crustal contamination 430 would also decrease $\mathrm{MgO}, \mathrm{Mg}^{\#}$ and $\varepsilon \mathrm{Nd}(\mathrm{t})$ values, increase initial ${ }^{87} \mathrm{Sr} /{ }^{86} \mathrm{Sr}$ ratios, and 431 contribute to the large variations observed in these values. Collectively, the evidence 432 suggests that a combination of crustal assimilation and fractional crystallization (AFC) 
433 were involved in the petrogenesis of the Lamasu intrusive rocks. The process is 434 isotopically modeled in Figure 12. A Neoproterozoic basement crust was selected with 60 435 ppm Sr, $40 \mathrm{ppm} \mathrm{Nd},\left({ }^{87} \mathrm{Sr} /{ }^{86} \mathrm{Sr}\right)_{\mathrm{i}}$ of 0.7206 and $\varepsilon_{\mathrm{Nd}}(\mathrm{t})$ value of $-8.31\left[\left({ }^{143} \mathrm{Nd} /{ }^{144} \mathrm{Nd}\right)_{\mathrm{i}}=\right.$ 436 0.51248] (Hu et al., 2000). The original magma of the Lamasu intrusive rocks is inferred 437 to have been derived from source rocks similar to the gabbros of the Bayingou ophiolites 438 (Xu et al., 2006a), with $127 \mathrm{ppm} \mathrm{Sr}, 6 \mathrm{ppm} \mathrm{Nd},\left({ }^{87} \mathrm{Sr} /{ }^{86} \mathrm{Sr}\right){ }_{\mathrm{i}}$ of 0.7036 and $\varepsilon_{\mathrm{Nd}}(\mathrm{t})$ value of $439+5.0\left[\left({ }^{143} \mathrm{Nd} /{ }^{144} \mathrm{Nd}\right)_{\mathrm{i}}=0.51174\right]$. On a $\left({ }^{143} \mathrm{Nd} /{ }^{144} \mathrm{Nd}\right)_{\mathrm{i}}$ versus $\left({ }^{87} \mathrm{Sr} /{ }^{86} \mathrm{Sr}\right)_{\mathrm{i}}$ plot $($ Fig. 12a), an 440 AFC trend with an assimilation rate (r) of 0.3 passes through the middle of the isotopic 441 range defined by the Lamasu intrusive rocks.

443 The genesis of adakites, however, is still a matter of debate, and a number of other 444 genetic models have been proposed, for example: (a) partial melting of thickened basaltic 445 lower crust (Model B) (e.g., Atherton and Petford, 1993; Chung et al., 2003; Condie, 446 2005; Wang et al., 2005, 2007b); (b) partial melting of delaminated lower crust (Model C) 447 (e.g., Kay and Kay, 1993; Xu et al., 2002; Gao et al., 2004; Wang et al., 2007b, 2006b; 448 Xiao and Clemens, 2007; Zhang et al., 2007); (c) crustal assimilation as well as fractional 449 crystallization from parental basaltic magmas (Model D) (e.g., Castillo et al., 1999; 450 Macpherson et al., 2006; Richards and Kerich, 2007). We consider these alternative processes below with specific reference to the Lamasu adakitic porphyries.

453 The geochemical characteristics of the Lamasu intrusive porphyries are inconsistent with 454 partial melting of thickened continental lower crust (Models B). Commonly, adakitic 455 rocks derived by melting of thickened lower crust are characterized by relatively low $456 \mathrm{MgO}$ or $\mathrm{Mg}^{\#}$ values (Fig. 5c-d), which are similar to those of experimental melts from 457 metabasalts and eclogites (Rapp et al., 1999; Rapp and Watson, 1995; Sen and Dunn, 458 1994). The Lamasu intrusive rocks, however, display distinctly higher $\mathrm{Mg}^{\#}$ values than 459 the experimental melts, although they have low $\mathrm{MgO}$ contents (Fig. 5c-d) (Rapp et al., 460 1999). Moreover, adakitic rocks formed by Model $\mathrm{B}$ generally have higher $\mathrm{K}_{2} \mathrm{O}$ contents 461 and are high-K calc-alkaline (Atherton and Petford, 1993; Muir et al., 1995; Wang et al., $4622005,2007 \mathrm{~b}$ ), but some of the Lamasu samples have lower $\mathrm{K}_{2} \mathrm{O}$ content and are 463 calc-alkaline (Fig. 3d). 
465 Based on their geochemical characteristics, high $\mathrm{Mg}^{\#}$ values (Fig. 5d) and relatively low $466 \varepsilon N d$ values (Fig. 8a), it might be argued that the Lamasu intrusive porphyries could have 467 been generated by partial melting of delaminated lower crust (Model C). In general, 468 however, adakitic rocks formed by delamination occur in within-plate setting and are 469 associated with contemporary within-plate or extension-related magmatic rock types (e.g., 470 A-type granites) (Gao et al., 2004; Wang et al., 2006b). The northwestern Tianshan area 471 is regarded as an active continental margin from the Late Devonian to the Early 472 Carboniferous (Xiao et al., 2008). Late Devonian to Early Carboniferous arc volcanic 473 rocks and granitoids occur widely in northwestern Tianshan and the Lamasu intrusive 474 porphyries were not associated with contemporary within-plate or extension-related 475 magmatic rocks (Long et al., 2008; Wang et al., 2009, 2006a, 2007c, 2006c) (Fig. 1). 476 Given that Devonian to Carboniferous calc-alkaline volcanic rocks and deep marine 477 volcanogenic sedimentary rocks dominate the northern Tianshan (Fig. 1) (Carroll et al., 478 1995), it seems unlikely that delamination of the lower crust took place in the Western 479 Tianshan during the Late Devonian.

481 It is also unlikely that fractional crystallization from parental basaltic magmas (Model C) 482 could account for the Lamasu intrusive porphyries. The most probable candidate for a 483 basaltic parental magma would be the Lamasu diabase. If olivine and pyroxene 484 fractionated from the diabase, then the derived magma would show a clear decrease in $485 \mathrm{MgO}$ contents and $\mathrm{Mg}^{\#}$ values with increasing $\mathrm{SiO}_{2}$ (Fig. 5c-d). However, the samples for 486 the Lamasu intrusive porphyries do not plot along this trend on a $\mathrm{SiO}_{2}$ versus $\mathrm{Mg}^{\#}$ 487 diagram (Fig. 5d). In addition, fractionation of olivine and pyroxene is inconsistent with 488 the depletion of HREE (e.g., Yb) (Fig. 4a). This is because these minerals are incapable 489 of incorporating HREE elements, and their formation would thus lead to concave-upward 490 HREE in the chondrite-normalized REE concentration patterns instead (Castillo et al., 491 1999). Moreover, adakitic rocks formed by high-pressure fractional crystallization 492 involving garnet generally display distinct geochemical characteristics (Macpherson et al., 493 2006), such as $\mathrm{Al}_{2} \mathrm{O}_{3}$ contents decreasing with increasing $\mathrm{SiO}_{2}$, and $\mathrm{Dy} / \mathrm{Yb}$ and $\mathrm{Sr} / \mathrm{Y}$ 494 ratios increasing with increasing $\mathrm{SiO}_{2}$. However, the Lamasu adakitic rocks do not 
exhibit such trends. $\mathrm{Al}_{2} \mathrm{O}_{3} / \mathrm{TiO}_{2}$ ratios vary between 32 and 91 for the Lamasu plagioclase

496 granites, and between 35 and 55 for the Lamasu granodiorites (Fig. 11a). These variations

497 are mainly controlled by $\mathrm{Ti}$ content (Fig. 11b). If the variations were entirely due to 498 fractionation, then it could be caused by a minor Ti phase or a combination of major 499 phases (plagioclase + hornblende?). A large change in Eu/Eu* (Fig. 11c) implies that 500 plagioclase was involved (with other minerals) rather than just fractionation of a minor 501 phase. Compatible major elements $\mathrm{Fe}$ and $\mathrm{Mg}$ decrease with increasing $\mathrm{Al} / \mathrm{Ti}$, (Fig. 502 11d-e), however, there is no clear trend between fractionation and $\mathrm{Sr} / \mathrm{Y}$ (Fig. 11f). 503 Similarly, the HREE do not support hornblende crystallization. Yb exhibits no trend or 504 increases with $\mathrm{Al} / \mathrm{Ti}$ and $\mathrm{Gd}$ displays a similar pattern (Fig. 11g-h). La/Yb also exhibits 505 no clear trend but the highest $\mathrm{Al} / \mathrm{Ti}$ value corresponds to the lowest $\mathrm{La} / \mathrm{Yb}$ value (Fig. 506 11i), which is not consistent with control by hornblende fractionation.

508 In summary, the Lamasu adakitic rocks were most probably produced by partial melting 509 of southward subducted oceanic crust in the Late Devonian ( $366 \mathrm{Ma})$, followed by 510 subsequent melt-mantle interaction and AFC by basement rocks.

\subsubsection{The Dabate dacites}

513 The Dabate dacites are intermediate in composition $\left(\mathrm{SiO}_{2}=62.12-64.38\right.$ wt.\% $)$ and

514 mostly metaluminous to peraluminous based on the A/CNK range of $0.89-1.3$. These 515 calc-alkaline, intermediate volcanic rocks were considered to have been products of 516 either fractional crystallization of mantle derived calc-alkaline basaltic magma (Barth et 517 al., 1995), or partial melting of juvenile sub-alkaline metabasaltic rocks (e.g., Defant and 518 Drummond, 1990; Rapp and Watson, 1995). Although the Dabate dacites have MgO 519 concentrations similar to that of modern adakites produced by melting of subducted 520 oceanic crust and subsequent interactions between slab melt and the mantle (e.g., Rapp et 521 al., 1999) (Fig. 5c-d), coupled with significantly lower Sr/Y (4.1-21.5) and higher Y 522 (19.3-41.4 ppm) and HREE (such as $\mathrm{Yb}=1.7-4.0 \mathrm{ppm}$ ) than adakites (Table 1). Hence, 523 the Dabate dacites are different in origin from adakites. Based on several lines of 524 evidence below, fractional crystallization of basaltic magma can also be excluded. The 525 Dabate dacites with large volumes of contemporaneous dacitic or dioritic magmatism, 
cannot be simply generated by fractional crystallization of basaltic magma. The Dabate dacite samples have nearly constant $\mathrm{Al}_{2} \mathrm{O}_{3}$ contents of 14.6-16.0 wt.\% and relatively uniform REE and trace element abundances and patterns (Fig. 4c-d). Major and trace elements concentrations versus $\mathrm{Mg}^{\#}$ or $\mathrm{MgO}$ plots (not shown) do not show systematic fractional crystallization trends from mafic to felsic magma.

The melting of a basaltic arc crust is a plausible mechanism for the petrogenesis of the Dabate dacites. In order to evaluate this process we use REE data for modeling of batch partial melting (Fig. 12b). Sample GNS30 of the Gongnisi basalt from northwestern Tianshan (Long et al., 2008) was selected as a proxy of juvenile lower crust beneath the NTOB. We assume that the partial melting took place under an amphibolite-facies condition and the initial mineralogical assemblages were Amph (amphibole): Plag (plagioclase): OPX (orthopyroxene) $=70: 20: 10$. The chondrite-normalized REEs pattern for the Dabate dacites is reproduced by $25-35 \%$ batch melting. In addition, some of the Dabate dacites have $\mathrm{MgO}$ concentrations and $\mathrm{Mg}^{\#}$ values (29-55) clearly higher than that of experimental melts (Fig.8c-d), indicating mantle-derived magmas were also possibly involved in the generation of the Dabate dacites. Therefore, we suggest that the Dabate dacites were generated by melting of juvenile basaltic lower crust, similar to the felsic calc-alkaline magmas from the southernmost Cascades, California (Borg and Clynne, 1998).

\subsubsection{The Dabate A-type granite porphyries}

It has been recognized that A-type granites can form in a variety of extensional tectonic environments, from continental back arc-extension to post-collision extension or within-plate tectonic settings (Eby, 1992; Förster et al., 1997; Turner et al., 1992; Whalen et al., 1987). The petrogenesis of a specific A-type granite is often controversial. Various genetic models invoke partial melting of crustal and mantle sources, fractional crystallization of basaltic compositions plus assimilation of crustal rocks and magma mixing (Collins et al., 1982; Eby, 1992; Kerr and Fryer, 1993; King et al., 1997; Whalen et al., 1987; Wu et al., 2002; Yang et al., 2006; Chen et al., 2009). Eby (1992) subdivided A-type granites into two sub-groups and suggested that they may have different origins 
and tectonic settings. The $\mathrm{A}_{1}$-type granites represent differentiates of magmas derived

558 from OIB-like sources emplaced in continental rifts or associated with intraplate

559 magmatism, whereas the $\mathrm{A}_{2}$-type granites are derived from melting of continental crust or

560 underplated mafic crust that has been through a cycle of continent-continent collision or

561 island-arc magmatism (Eby, 1992).

562

563 A purely crustal origin is untenable for the Dabate A-type granite porphyries (Bonin,

564 2007). On the one hand, the consistent slightly negative initial $\mathrm{Nd}$ isotopic compositions

$565(\varepsilon \mathrm{Nd}(t)=-1.72$ to 0.00$)$ of the Dabate A-type granite porphyries and the absence of

566 inherited zircon with the Neoproterozoic ages preclude their derivation from melting of a

567 highly evolved ancient continental crust, because the Neoproterozoic basement crust of

568 the NTOB has negative $\mathrm{Nd}$ isotopic compositions $((\varepsilon \mathrm{Nd}(t)=-8.5-11.7, \mathrm{Hu}$ et al., 2000$)$.

569 On the other hand, positive zircon $\varepsilon_{\mathrm{Hf}}(t)$ values $(+0.5$ to +8.3$)$ of the Dabate A-type

570 granite (Fig. 9b) imply a significant input of juvenile, mantle derived, material during

571 magma generation and preclude a purely crustal origin. The Dabate A-type granite

572 porphyries also could not have been produced by extreme differentiation of the Dabate

573 dacites, because (1) there is a "Daly gap" between dacites and A-type granites; (2) all

574 samples have a nearly constant $\mathrm{Al}_{2} \mathrm{O}_{3}$ content of $12-13 \%$ over the whole $\mathrm{SiO}_{2}$ range

575 (Appendix 3), and have consistent REE and trace element abundances and patterns (Fig.

$5764 \mathrm{c}-\mathrm{d})$.

578 The Dabate A-type granite porphyries contain late Carboniferous zircons (319-317 Ma)

579 (Fig. 2b) that formed contemporaneously with the Dabate dacites (316 $\pm 6 \mathrm{Ma}$ ). Given

580 that Late Carboniferous igneous rocks are widespread along the NTOB (Wang et al.,

581 2006a; 2007c; 2006c) (Fig. 1 and 10), we suggest that the source of the Dabate A-type

582 granite porphyries was a Late Carboniferous arc-related igneous protolith combined with

583 the input of mafic magmas. The highest $\varepsilon_{\mathrm{Hf}}(t)$ value of +11.7 calculated for inherited 319

584 Ma zircons, from sample 06XJ13 (Fig. 9b), is near the mantle value (Griffin et al., 2000).

585 Therefore, the Dabate A-type granite porphyries were most likely generated by partial

586 melting of a source rock which possibly contained an igneous rock formed during the late

587 Carboniferous. Melting of this source rock was induced by mantle-derived hot mafic 
magmas during Early Permian crustal extension.

5905.3 Coeval mineralization and magmatism in the northern Tianshan arc: Episodic

591 metallogenic history

592 The new age data determined during this study as well as those reported previously

593 indicate that the $\mathrm{Cu}-\mathrm{Mo}-\mathrm{Au}$ deposits within the NTOB (Fig. 1) are the product of discrete

594 Late Devonian to Late Carboniferous events (Table 2).

596 Late Devonian to early Carboniferous gold-copper deposits are widespread throughout 597 the northern Tianshan arc (Fig. 1). A typical example is the Lailisigao'er porphyry 598 Cu-Mo deposit, which gave a $359 \pm 8 \mathrm{Ma}$ (Re-Os isochron) molybdenite (Li et al., 2006).

599 This age is consistent with the 362-345 Ma ages of ore-related porphyries ( $\mathrm{Li}$ et al., 2006;

600 Zhang et al., 2009). The Lamasu porphyry $\mathrm{Cu}$ deposit and Axi low-sulfidation type 601 epithermal gold deposit were both formed at this time (Table 2).

602

603 The Kekesai deposit (Zhang et al., 2008a) is an example of an NTOB porphyry Cu-Mo 604 deposits formed during the Late Carboniferous (Fig. 1, Table 2). As noted above, the 605 Dabate porphyry Cu-Mo deposit also has a molybdenite Re-Os isochron age of $301 \pm 20$ 606 Ma (Zhang et al., 2006b). In addition, the Balkhash-Ili zone (Kazakhstan) in the western 607 extension of the NTOB contains a number of late Carboniferous large tonnage porphyry 608 deposits, including the 330 Ma Kounrad and the 320 Ma Aktogai, Aidarly, Kyzilkia and 609 Koksai porphyry deposits and the $\sim 320$ Ma Sayak skarn deposit (Seltmann and Porter, 610 20005).

612 No Early Permian $\mathrm{Cu}-\mathrm{Au}$ deposits have been identified, although Early Permian intrusive 613 rocks are common along the NTOB (Fig. 1). Given the ages summarized here, $614 \mathrm{Cu}$-Au-Mo mineralization within the NTOB may have been episodic and associated with 615 particular magmatic episodes during the Late Devonian to Early Carboniferous and the 616 Late Carboniferous (Table 2). The idea of episodic mineralization is a preliminary one 617 and further studies and an enlarged database are obviously required to test this 618 hypothesis. 
$620 \quad 5.4$ Tectonic evolution

621 The NTOB is a part of Central Asian Orogenic Belt, which has been the subject of 622 numerous tectonic studies (e.g., Carroll et al., 1995; Gao et al., 1998; Sengör et al., 1993;

623 Windley et al., 1990; Xiao et al., 2008). However, a consensus for the tectonic evolution

624 of this orogenic belt has not been achieved. In the following section, we summarize the 625 tectonic evolution of the northwestern Tianshan mainly based on data from Late 626 Devonian to Early Permian igneous rocks (Fig. 13).

628 5.4.1. 455-345 Ma (Fig. 13a)

629 Late Devonian to Early Carboniferous (366-345 Ma) volcanic and plutonic rocks, 630 including the Lamasu intrusive rocks, are sporadically distributed along northwestern 631 Tianshan (Fig. 1 and 10) (Xu et al., 2006b; Zhai et al., 2006; Long et al., 2008; Wang et 632 al., 2007a). Geochemically, they display Nb, Ta and Ti depletions and enrichment of 633 mobile LILE, similar to subduction zone magmatism along the northwestern Tianshan 634 (Fig. 1 and 4b). As with the Axi volcanic rocks (Long et al., 2008; Wang et al., 2007a), 635 all of the Late Devonian to Early Carboniferous porphyries (Lamasu, Lailisigao'er and 636 Axi) plot in the volcanic arc field on $\mathrm{Y}-\mathrm{Nb}$ versus $\mathrm{Yb}-\mathrm{Ta}$ tectonic discrimination 637 diagrams (Pearce et al, 1984). These characteristics suggest that these porphyries may 638 have been formed at an active continental margin. Recently, Hu et al., (2008) showed that 639 medium- to coarse-grained amphibolites south of Wenquan were formed at $455.1 \pm 2.7$

$640 \mathrm{Ma}$ and $451.4 \pm 5.7 \mathrm{Ma}$ (zircon $\mathrm{U}-\mathrm{Pb}$ ages), respectively, in an island-arc setting. These 641 characteristics suggest that the initiation of southward subduction of the Junggar Ocean 642 beneath the Yili - Central Tianshan block was present as early as the Late Ordovician, 643 and the northwestern Tianshan continental arc magmatism and associated $\mathrm{Cu}$ or $\mathrm{Au}$ 644 mineralizations were formed between the Late Devonian to the Early Carboniferous (Fig. 645 13a).

646

647 5.4.2.345-320 Ma (Fig. 13b)

648 It is noteworthy that a magmatic gap or quiescent period existed between ca. 345 and 320

649 Ma after a period of continuous subduction that resulted in extensive Late Devonian to 
650 Early Carboniferous magmatism (Fig. 10). We propose that, a period of "flat-subduction" 651 can account for this ca. 345-320 Ma quiescence (Fig. 13b). In this model, mantle wedge 652 asthenosphere was squeezed out by the flattening of the subducting slab, thus terminating 653 arc magmatism (Kay and Mpodozis, 2001; Booker et al., 2004). An analogous mantle 654 displacement process has been documented beneath the modern Central Andes (Kay and 655 Mpodozis, 2001; Ramos and Folguera 2009) where flat subduction also occurs.

\subsubsection{7-306 Ma (Fig. 13c)}

658 Subduction will generally revert from flat to normal angles once features such as 659 topographic highs on the ocean floor or young crust generated at nearby spreading 660 centres are no longer present. Such transitions are common in the geological record and 661 numerous transitions between subduction angles are recognized in, for example, the 662 Andes and central-south Tibet (Ramos and Folguera 2009, Ding et al., 2003; Wen et al., 663 2008; Lee et al., 2009). Before the final stage of closure of the Junggar Ocean, the 664 oceanic slab is therefore likely to have undergone roll-back to normal, steeper, angles of 665 slab subduction, induced asthenospheric convection and enhanced corner flow (Lee et al., 666 2009) (Fig. 13c). The continental arc setting in western Tianshan continued until the Late 667 Carboniferous (Fig. 13c). Evidence for an active margin include gabbros and 668 plagiogranites of the Bayingou ophiolite with zircon U-Pb ages of $344 \pm 3 \mathrm{Ma}$ and $325 \pm$ $6697 \mathrm{Ma}$, respectively (Xu et al., 2006a). Wang et al. (2007c, 2006c) described late 670 Carboniferous adakite, high $\mathrm{Mg}$ andesite and $\mathrm{Nb}$-enriched arc basalt suites in 671 northwestern Tianshan similar to those in Cenozoic arcs, and suggested Carboniferous 672 oceanic subduction along the northern margin of northwestern Tianshan. Similarly, Wang

673 et al., (2007a) and Long et al., (2008) demonstrated that Carboniferous volcanic rocks of 674 the same area belong to the calc-alkalic series, and have geochemical characteristics of 675 arc volcanic rocks. The Dabate dacites $(316 \pm 6 \mathrm{Ma})$ also show a typical arc-like 676 geochemical nature (Figs. $4 \mathrm{~d}$ and $7 \mathrm{a}-\mathrm{b}$ ). We thus conclude that both the Late 677 Carboniferous volcanic and plutonic rocks and the coeval Mo mineralization in 678 northwestern Tianshan were related to the southward subduction of the Junggar Ocean 679 beneath the YCTP. 
682 Our new data for the Early Permian (289 $\pm 3 \mathrm{Ma}$ ) Dabate A-type granite porphyries are 683 consistent with the proposed Early Permian rocks more likely mark a post-collisional 684 extension event (Fig. 16d). There is other evidence in support of this conclusion. (1) 685 Several A-type granites with ages around 290 Ma have been found in southern Tianshan 686 (Konopelko et al., 2007), implying that southern Tianshan had entered a post-collisional 687 stage by the Early-Permian. (2) High-K granites on the southern slope of the Alataw 688 Mountains, with zircon U-Pb ages of $298.4 \pm 5.7 \mathrm{Ma}$ and $292 \pm 4.9 \mathrm{Ma}$ have been 689 interpreted to be post-collisional granitic rocks, based on geochronological data and field 690 studies (Liu et al., 2005). Two-mica granites from the southern margin of the Alataw 691 Mountains have a similar zircon U-Pb age (290 \pm 7 Ma; Chen et al., 2007) and whole 692 rock ${ }^{40} \mathrm{Ar}-{ }^{39} \mathrm{Ar}$ age $(299 \pm 6 \mathrm{Ma}$; Chen et al., 1994), interpreted as representing a product 693 of post-collisional crustal anatexis. (3) Wang et al. (2009) suggested that 294-280 Ma 694 high-K calc-alkaline granites in the Borohoro area were formed in a post-collisional 695 setting. (4) The diabasic porphyry formed in a post-collisional setting in the Baiyanggou 696 area near the Urumqi city yields a zircons U-Pb age of $289 \pm 5 \mathrm{Ma}$ (Shu et al., 2005). (5)

697 Early Permian bimodal magmatism in the region (Che et al., 1994) probably represents 698 the early products of extension following the collision between the Junggar plate and the 699 YCTP, and was associated with emplacement of the post-collisional Dabate A-type 700 granite porphyries. In addition, an Early Permian regional dextral faulting episode in the 701 Tianshan range is considered to have resulted from late collisional strike-slip 702 (Laurent-Charvet et al., 2002).

704 Two alternative geodynamic models may explain magmatism in post-collisional settings:

705 (a) slab breakoff (Davies and von Blackenburg, 1995; Whalen et al., 2006) and (b) 706 large-scale lithosphere delamination (e.g. Lustrino, 2005) or convective removal of the 707 lithosphere (e.g. Houseman et al., 1981). These processes are capable of causing partial 708 melting in various sources including the ascended asthenosphere, the enriched 709 lithospheric mantle, and even the overlying crust. The second model requires the removal 710 of dense lithospheric root and wholesale melting of the lower crust as hot asthenosphere 711 was emplaced close to the Moho (Houseman et al., 1981; Lustrino, 2005). Thus, the 
712 models predict large diffuse, non-linear zones of magmatism within the affected area

713 (e.g., Wu et al., 2003; Whalen et al., 2006, 2010; Zhang et al., 2007; Aydin et al., 2008;

714 Zhao et al., 2009; Liu et al., 2010). In contrast, the slab break-off model predicts a

715 relatively narrow, linear zone of magmatism aligned with a major lineament (Davies and

716 von Blackenburg, 1995; Whalen et al., 2006, 2010; Oyhantçabal et al., 2007). The slab

717 break-off mechanism is favoured because the resultant narrow region of upwelling hot

718 asthenosphere provides the appropriate thermal flux to melt overlying lower crust and

719 generate the Permian A-type granitic rocks, which display a roughly linear distribution

720 along the NTOB (Fig. 1; Fig. 13d). This inference is also supported by the presence of

721 Early Permian mafic-ultramafic magmatic complexes along the NTOB (Zhou et al., 2004)

722 that are coeval with the A-type granites and likely derived from asthenoshperic mantle

723 sources (Whalen et al., 2006).

\section{7. Conclusions}

726 The Lamasu intrusion associated with $\mathrm{Cu}-\mathrm{Au}$ deposits in the northwestern Tianshan area 727 are calc-alkaline plagioclase granites and granodiorite porphyries. They exhibit 728 geochemical and petrologic characteristics that are similar to adakites. In the Dabate area, 729 dacites are also associated with $\mathrm{Cu}-\mathrm{Mo}$ deposits, but the granite porphyries, which are 730 barren of metal mineralization, exhibit the geochemical and petrologic characteristics of $731 \quad \mathrm{~A}_{2}$-type granites.

733 New zircon U-Pb ages indicate that the Lamasu intrusive rocks were emplaced at $366 \pm$ 734 3Ma, whereas the Dabate dacite and A-type granite were emplaced at $316 \pm 4 \mathrm{Ma}$ and $735289 \pm 3 \mathrm{Ma}$, respectively. Thus, the magmatic rocks in the Lamasu-Dabate area were 736 mainly generated in Late Devonian-Early Permian.

738 The Lamasu intrusive rocks were most likely generated by partial melting of southward 739 subducted Junggar oceanic crust during the Late Devonian, and subsequent melt-mantle 740 interaction and AFC by basement rocks in a normal, steep, subduction setting. The Late 741 Carboniferous Dabate dacites were generated by melting of juvenile basaltic lower crust. 742 A magmatic gap or quiescent period that existed between ca. 345 and $320 \mathrm{Ma}$ is 
743 interpreted as a "flat-subduction" episode, which was likely followed by roll-back of the

744 slab to steeper angles in a return to normal slab subduction during the Late Carboniferous.

745 Therefore, the Late Devonian to Late Carboniferous volcanic and plutonic rocks in

746 northwestern Tianshan constitute a typical calc-alkaline arc assemblage formed at an

747 active continental margin as a result of southward subduction of the Junggar Ocean.

748

749 The Early Permian Dabate A-type granite porphyries were generated by partial melting of

750 late Carboniferous igneous rocks by upwelling of hot asthenospheric mantle because of 751 slab break-off during a post-collisional stage. Such Early Permian A-type granites mark

752 the start of an extensional tectonic regime after the closure of the Junggar Ocean by the 753 end of the Carboniferous.

\section{Acknowledgements}

756 We sincerely thank Professor Nelson Eby and two anonymous reviewers for their 757 constructive and helpful reviews. We appreciate the assistance of Professors Liu 758 Yongsheng and Yang Jinhui, and Ms./Mr. Yang Yueheng, Xie Liewei, Chen Haihong, 759 Liu Ying, $\mathrm{Hu}$ Guangqian, Ma Jinlong, Liang Xirong and $\mathrm{Tu}$ Xianglin for 760 geochronological and geochemical analyses. This study was jointly supported by the

761 Major State Basic Research Program (973 Program) of People's Republic of China (No.

762 2007CB411308), the National Natural Science Foundation of China (Grant No. 763 40721063), the Knowledge Innovation Program of Chinese Academy of Sciences 764 (KZCX2-YW-128), and the Institute for Geoscience Research (TIGeR) at Curtin 765 University of Technology. This is contribution No. IS-XXXX from GIGCAS.

APPENDIX A. SUPPLEMENTARY DATA

769 Supplementary data associated with this article can be found, in the online version, at 770 XXXXXX. 
[First Authors Last Name] Page 27

\section{References}

Allen, M.B., Sengor, A.M.C., Natal'in, B.A., 1995. Junggar, Turfan and Alakol basins as Late Permian to? Early Triassic extensional structures in a sinistral shear zone in the Altaid Orogenic Collage, Central Asia. Journal of the Geological Society 152(2), 327-338.

Allen, M.B., Windley, B.F., Zhang, C., 1993. Palaeozoic collisional tectonics and magmatism of the Chinese Tien Shan, central Asia. Tectonophysics 220(1-4), 89-115.

Atherton, M.P., Petford, N., 1993. Generation of sodium-rich magmas from newly underplated basaltic crust. Nature 362(6416), 144-146.

Aydin, F., Karsli, O., Chen, B., 2008. Petrogenesis of the Neogene alkaline volcanics with implications for post-collisional lithospheric thinning of the Eastern Pontides, NE Turkey. Lithos 104(1-4), 249-266.

Barbarin, B., 1999. A review of the relationships between granitoid types, their origins and their geodynamic environments. Lithos 46(3), 605-626.

Barth, A.P., Wooden, J.L., Tosdal, R.M., Morrison, J., 1995. Crustal contamination in the petrogenesis of a calc-alkalic rock series: Josephine Mountain intrusion, California. Geological Society of America Bulletin 107(2), 201-212.

Belousova, E.A., Griffin, W.L., Suzanne, Y.O.R., Fisher, N.I., 2002. Igneous zircon: Trace element composition as an indicator of source rock type. Contributions to Mineralogy and Petrology 143 (5), 602-622.

Bonin, B., 2007. A-type granites and related rocks: Evolution of a concept, problems and prospects. Lithos 97(1-2), 1-29.

Booker, J.R., Favetto, A., Pomposiello, M.C., 2004. Low electrical resistivity associated with plunging of the Nazca flat slab beneath Argentina. Nature 429(6990), 399-403.

Borg, L.E., Clynne, M.A., 1998. The Petrogenesis of Felsic Calc-alkaline Magmas from the Southernmost Cascades, California: Origin by Partial Melting of Basaltic Lower Crust. Journal of Petrology 39(6), 1197-1222.

Carroll, A.R., Graham, S.A., Hendrix, M.S., Ying, D., Zhou, D., 1995. Late Paleozoic tectonic amalgamation of northwestern China; sedimentary record of the northern Tarim, northwestern Turpan, and southern Junggar basins. Geological Society of America Bulletin 107(5), 571-594.

[Insert Running title of $<72$ characters] 
801

802

803

804

805

806

807

808

809

810

811

812

813

814

815

816

817

818

819

820

821

822

823

824

825

826

827

828

829

830

Castillo, P.R., Janney, P.E., Solidum, R.U., 1999. Petrology and geochemistry of Camiguin Island, southern Philippines: insights to the source of adakites and other lavas in a complex arc setting. Contributions to Mineralogy and Petrology 134(1), 33-51.

Che, Z.L., Liu, H.F., Liu, L., 1994. Forming and evolution of the Middle Tianshan. The Geological Publishing House Beijing, 135 pp (in Chinese with English abstract).

Chen, B.H., Luo, Z.H., Jia, B.H., Liu, W., W ei, Y., Han, Y.G., 2007. SHRIMP U-Pb zircon geochronology of igneous rocks from southern margin of the Alataw Mountains, Xinjiang, China. Acta Petrologica Sinica 23(7), 1756-1764 (in Chinese with English abstract).

Chen, L., Ma, C.Q., She, Z.B., Mason, R., Zhang, J.Y., Zhang, C., 2009. Petrogenesis and tectonic implications of A-type granites in the Dabie orogenic belt, China: geochronological and geochemical constraints. Geological Magazine 146( 5), 638-651

Chen, J.F., Chen, D.G., Li, X.M., Zhou, T.X., Foland, K.A., 1994. K-Ar and ${ }^{40} \mathrm{Ar} /{ }^{39} \mathrm{Ar}$ geochronology of granites from the Alataw Mountains, northwest Xinjiang, China. Acta Petrologica Sinica 10(2), 184-192 (in Chinese with English abstract).

Chung, S.L., Liu, D.Y., Ji, J.Q., Chu, M.F., Lee, H.Y., Wen, D.J., Lo, C.H., Lee, T.Y., Qian, Q., Zhang, Q., 2003. Adakites from continental collision zones: Melting of thickened lower crust beneath southern Tibet. Geology 31(11), 1021-1024.

Chung, S.L., Chu, M.F., Zhang, Y.Q., Xie, Y.W., Lo, C.H., Lee, T.Y., Lan, C.Y., Li, X.H., Zhang, Q., Wang, Y.Z., 2005. Tibetan tectonic evolution inferred from spatial and temporal variations in post-collisional magmatism. Earth-Science Reviews 68(3-4), 173-196.

Coleman, R.G., 1989. Continental growth of Northwest China. Tectonics 8(3), 621-635.

Collins, W., Beams, S., White, A., Chappell, B., 1982. Nature and origin of A-type granites with particular reference to southeastern Australia. Contributions to Mineralogy and Petrology 80(2), 189-200.

Condie, K.C., 2005. TTGs and adakites: are they both slab melts? Lithos 80(1-4), 33-44.

Davies, J.H., von Blanckenburg, F., 1995. Slab breakoff: A model of lithosphere detachment and its test in the magmatism and deformation of collisional orogens. Earth and Planetary Science Letters 129(1-4), 85-102.

[Insert Running title of $<72$ characters] 
831

832

833

834

835

836

837

838

839

840

841

842

843

844

845

846

847

848

849

850

851

852

853

854

855

856

857

858

859

860

861

Defant, M.J., Drummond, M.S., 1990. Derivation of some modern arc magmas by melting of young subducted lithosphere. Nature 347(6294), 662-665.

Defant, M.J., Kepezhinskas, P., 2001. Adakites: A review of slab melting over the past decade and the case for a slab-melt component in arcs. EOS 82, 65-69

Defant, M.J., Kepezhinskas, P., Defant, M.J., Xu, J.F., Kepezhinskas, P., Wang, Q., Zhang, Q. and Xiao, L., 2002. Adakites: some variations on a theme. Acta Petrologica Sinica 18(2), 129-142.

Ding, L., Kapp, P., Zhong, D.L., Deng, W.M., 2003. Cenozoic Volcanism in Tibet: Evidence for a Transition from Oceanic to Continental Subduction. Journal of Petrology 44(10), 1833-1865.

Ding, X., Lundstrom, C., Huang, F., Li, J., Zhang, Z.M., Sun, X.M., Liang, J.L. and Sun, W.D., 2009. Natural and experimental constraints on formation of the continental crust based on niobium-tantalum fractionation: International Geology Review 51(6), 473-501.

Eby, G.N., 1990. The A-type granitoids: A review of their occurrence and chemical characteristics and speculations on their petrogenesis. Lithos 26(1-2), 115-134.

Eby, G.N., 1992. Chemical subdivision of the A-type granitoids: petrogenetic and tectonic implications. Geology 20(7), 641-644.

Foley, S., Tiepolo, M., Vannucci, R., 2002. Growth of early continental crust controlled by melting of amphibolite in subduction zones. Nature 417(6891), 837-840.

Förster, H.J., Tischendorf, G., Trumbull, R.B., 1997. An evaluation of the Rb vs. $(\mathrm{Y}+\mathrm{Nb})$ discrimination diagram to infer tectonic setting of silicic igneous rocks. Lithos 40(2-4), 261-293.

Frost, B.R., Barnes, C.G., Collins, W.J., Arculus, R.J., Ellis, D.J., Frost, C.D., 2001. A Geochemical Classification for Granitic Rocks. Journal of Petrology 42(11), 2033-2048.

Gao, J., Li, M.S., Xiao, X.C., Tang, Y.Q., He, G.Q., 1998. Paleozoic tectonic evolution of the Tianshan Orogen, northwestern China. Tectonophysics 287(1-4), 213-231.

Gao, S., Rudnick, R.L., Yuan, H.L., Liu, X.M., Liu, Y.S., Xu, W.L., Ling, W.L., Ayers, J., Wang, X.C., Wang, Q.H., 2004. Recycling lower continental crust in the North China Craton. Nature 432(7019), 892-897.

Geng, H., Sun, M., Yuan, C., Xiao, W., Xian, W., Zhao, G., Zhang, L., Wong, K., Wu, F., 2009. Geochemical, Sr-Nd and zircon U-Pb-Hf isotopic studies of Late Carboniferous

[Insert Running title of $<72$ characters] 

magmatism in the West Junggar, Xinjiang: Implications for ridge subduction? Chemical Geology 266(3-4), 364-389.

Golovanov, I.M., Seltmann, R., Kremenetsky, A.A., 2005. The porphyry Cu-Au/Mo deposits of Central Eurasia 2. The Almalyk (kal'makyr-dalnee) and saukbulak $\mathrm{Cu}-\mathrm{Au}$ porphyry systems, Uzbekistan. In: T.M. Porter (Editor), Super Porphyry Copper \& Gold Deposits. PGC Publishing, Adelaide, Australia, pp. 513-523.

Griffin, W.L., Pearson, N.J., Belousova, E., Jackson, S.E., van Achterbergh, E., O'Reilly, S.Y., Shee, S.R., 2000. The Hf isotope composition of cratonic mantle: LAM-MC-ICPMS analysis of zircon megacrysts in kimberlites. Geochimica et Cosmochimica Acta 64(1), 133-147.

Guan. M.Z., Zeng, X.R., Dai, Y.L, Wei, J.T., Wang, H., Duan, S.Z., Zhu, Y., 1990. Comprehensive studies of geology, geochemistry and geophysics and targets selection in Lamasu Copper-polymetallic region. National 305 Project Items (No.4-7) (In Chinese).

Guo, Z., Wilson, M., Liu, J., 2007. Post-collisional adakites in south Tibet: Products of partial melting of subduction-modified lower crust. Lithos 96(1-2), 205-224.

Han, B.F., Guo, Z.J., Zhang, Z.C., Zheng, L., Chen, J.F., Song, B., 2010. Age, geochemistry, and tectonic implications of a late Paleozoic stitching pluton in the North Tian Shan suture zone, western China. Geological Society of America Bulletin 122(3-4), 627-640.

Houseman, G.A., McKenzie, D.P., Molnar, P., 1981. Convective instability of a thickened boundary layer and its relevance for the thermal evolution of continental convergent belts. Journal of Geophysical Research 86, 6115-6132.

Hu, A.Q., Jahn, B.M., Zhang, G.X., Chen, Y.B., Zhang, Q.F., 2000. Crustal evolution and Phanerozoic crustal growth in northern Xinjiang: $\mathrm{Nd}$ isotopic evidence. Part I. Isotopic characterization of basement rocks. Tectonophysics 328(1-2), 15-51.

Hu, A.Q., Wei, G.J., Zhang, J.B., Deng, W.F., Chen, L.L., 2008. SHRIMP U-Pb ages for zircons of the amphibolites and tectonic evolution significance from the Wenquan domain in the West Tianshan Mountains, Xinjiang, China. Acta Petrologica Sinica 24(12), 2731-2740 (in Chinese with English abstract).

Irvine, T.N., Baragar, W.R.A., 1971. A Guide to the Chemical Classification of the Common Volcanic Rocks. Canadian Journal of Earth Sciences 8(5), 523-548. 
892

893

894

895

896

897

898

899

900

901

902

903

904

905

906

907

908

909

910

911

912

913

914

915

916

917

918

919

920

921

Kay, R.W., 1978. Aleutian magnesian andesites: Melts from subducted Pacific ocean crust. Journal of Volcanology and Geothermal Research 4(1-2), 117-132.

Kay, R.W., Kay, S.M., 1993. Delamination and delamination magmatism. Tectonophysics 219(1-3), 177-189.

Kay, S.M., Mpodozis, C., 2001. Central Andean Ore Deposits Linked to Evolving Shallow Subduction Systems and Thickening Crust. GSA Today 11(3), 4-9.

Kay, S.M., Ramos, V.A., Marquez, M., 1993. Evidence in Cerro Pampa volcanic rocks for slab-melting prior to ridge-trench collision in southern South America. Journal of Geology 101, 703-714.

Kerr, A., Fryer, B.J., 1993. Nd isotope evidence for crust-mantle interaction in the generation of A-type granitoid suites in Labrador, Canada. Chemical Geology 104(1-4): 39-60.

King, P.L., White, A.J.R., Chappell, B.W., Allen, C.M., 1997. Characterization and origin of aluminous A-type granites from the Lachlan Fold Belt, Southeastern Australia. Journal of Petrology 38(3), 371-391.

Konopelko, D., Biske, G., Seltmann, R., Eklund, O., Belyatsky, B., 2007. Hercynian post-collisional A-type granites of the Kokshaal Range, Southern Tien Shan, Kyrgyzstan. Lithos 97(1-2), 140-160.

Kröner, A., Hegner, E., Lehmann, B., Heinhorst, J., Wingate, M.T.D., Liu, D.Y., Ermelov, P., 2008. Palaeozoic arc magmatism in the Central Asian Orogenic Belt of Kazakhstan: SHRIMP zircon ages and whole-rock Nd isotopic systematics. Journal of Asian Earth Sciences 32(2-4), 118-130.

Laurent-Charvet, S., Charvet, J., Shu, L., Ma, R., Lu, H., 2002. Palaeozoic late collisional strike-slip deformations in Tianshan and Altay, Eastern Xinjiang, NW China. Terra Nova 14(4), 249-256.

Lee, H.-Y., Chung, S.-L., Lo, C.-H., Ji, J., Lee, T.-Y., Qian, Q., Zhang, Q., 2009. Eocene Neotethyan slab breakoff in southern Tibet inferred from the Linzizong volcanic record. Tectonophysics 477, 20-35.

Liang, J.L., Ding, X., Sun, X.M., Zhang, Z.M., Zhang, H., Sun, W.D., 2009. Nb/Ta fractionation observed in eclogites from the Chinese Continental Scientific Drilling Project: Chemical Geology 268, 27-40.

[Insert Running title of $<72$ characters] 
Liégeois, J.P., Navez, J., Hertogen, J., Black, R., 1998. Contrasting origin of post-collisional high-K calc-alkaline and shoshonitic versus alkaline and peralkaline granitoids. The use of sliding normalization. Lithos 45(1-4), 1-28.

Li, H.Q., Wang, D.H., Wan, Y., Qu, W.J., Zhang, B., Lu, Y.F., Mei, Y.P., Zou, S.L., 2006. Isotopic geochronology study and its significance of the Lailisigao'er Mo deposit, Xinjiang. Acta Petrologica Sinica 22(1005), 2437-2443 (in Chinese with English abstract).

Liu, D.Q., Chen, Y.C., Wang, D.H., Tang, Y.L., Zhou, R.H., Wang, J.L., Li, H.Q., Chen, F.W., 2003. A Discussion on Problems Related to Mineralization of Tuwu-Yandong $\mathrm{Cu}-\mathrm{Mo}$ orefield in Hami, Xinjiang. Mineral Deposits 22(4), 334-344 (in Chinese with English abstract).

Liu, S., Hu, R., Gao, S., Feng, C., Feng, G., Coulson, I.M., Li, C., Wang, T., Qi, Y., 2010. Zircon $\mathrm{U}-\mathrm{Pb}$ age and Sr-Nd-Hf isotope geochemistry of Permian granodiorite and associated gabbro in the Songliao Block, NE China and implications for growth of juvenile crust. Lithos 114(3-4), 423-436.

Liu, W., Fei, P.X., 2006. Methane-rich fluid inclusions from ophiolitic dunite and post-collisional mafic-ultramafic intrusion: The mantle dynamics underneath the Palaeo-Asian Ocean through to the post-collisional period. Earth and Planetary Science Letters 242(3-4), 286-301.

Liu, Z.Q., Han, B.F., Ji, J.Q., Li, Z.H., 2005. Ages and geochemistry of the post-collisional granitic rocks from Eastern Alataw Mountains, Xinjiang, and implications for vertical crustal growth. Acta Petrologica Sinica 21(3), 623-639 (in Chinese with English abstract).

Long, L.L., Gao, J., Qian, Q., Xiong, X.M., Wang, J.B., Wang, Y.W., Gao, L.M., 2008. Geochemical charactersitics and tectonic setting of Carboniferous volcanic rocks form Yili region, western Tianshan. Acta Petrologica Sinica 24(4), 0699-710 (in Chinese with English abstract).

Lustrino, M., 2005. How the delamination and detachment of lower crust can influence basaltic magmatism. Earth-Science Reviews 72(1-2), 21-38. 
951

952

953

954

955

956

957

958

959

960

961

962

963

964

965

966

967

968

969

970

971

972

973

974

975

976

Ma, C., Li, Z., Ehlers, C., Yang, K., Renjing, W., 1998. A post-collisional magmatic plumbing system: Mesozoic granitoid plutons from the Dabieshan high-pressure and ultrahigh-pressure metamorphic zone, east-central China. Lithos 45(1-4), 431-456.

Macpherson, C.G., Dreher, S.T., Thirlwall, M.F., 2006. Adakites without slab melting: High pressure differentiation of island arc magma, Mindanao, the Philippines. Earth and Planetary Science Letters 243(3-4), 581-593.

Martin, H., Smithies, R.H., Rapp, R., Moyen, J.F., Champion, D., 2005. An overview of adakite, tonalite-trondhjemite-granodiorite (TTG), and sanukitoid: relationships and some implications for crustal evolution. Lithos 79(1-2), 1-24.

Massimo, C., Dmitry, K., Reimar, S., Robert, A.C., 2006. Lead isotope variations across terrane boundaries of the Tien Shan and Chinese Altay. Mineralium Deposita 41(5), 411-428.

McKenzie, D., O'Nions, R.K., 1991. Partial Melt Distributions from Inversion of Rare Earth Element Concentrations. Journal of Petrology 32(5), 1021-1091.

Moyen, J.-F., Stevens, G., 2006. Experimental constraints on TTG petrogenesis: implications for Archean geodynamics. in Archean geodynamics and environments. K. Benn, J.-C. Mareschal and K. C. Condie, Eds., AGU.monographs 164, 149-178.

Muir, R.J., Weaver, S.D., Bradshaw, J.D., Eby, G.N., Evans, J.A., 1995. The Cretaceous Separation Point batholith, New Zealand: granitoid magmas formed by melting of mafic lithosphere. Journal of the Geological Society 152(4), 689-701.

Mungall, J.E., 2002. Roasting the mantle: Slab melting and the genesis of major Au and Au-rich $\mathrm{Cu}$ deposits. Geology 30(10), 915-918.

Oyhantçabal, P., Siegesmund, S., Wemmer, K., Frei, R., Layer, P., 2007. Post-collisional transition from calc-alkaline to alkaline magmatism during transcurrent deformation in the southernmost Dom Feliciano Belt (Braziliano-Pan-African, Uruguay). Lithos 98(1-4), 141-159.

Pearce, J.A., Harris, N.B.W., Tindle, A.G., 1984. Trace Element Discrimination Diagrams for the Tectonic Interpretation of Granitic Rocks. Journal of Petrology 25(4): 956-983.

Peccerillo, A., Taylor, S.R., 1976. Geochemistry of Eocene calc-alkaline volcanic rocks from the Kastamonu area, Northern Turkey. Contributions to Mineralogy and Petrology 58(1), 63-81.

[Insert Running title of $<72$ characters] 
981

982

983

984

985

986

987

988

989

990

991

992

993

994

995

996

997

998

999

1000

1001

1002

1003

1004

1005

1006

1007

1008

1009

1010

1011

Pirajno, F., Mao, J.W., Zhang, Z.C., Zhang, Z.H., Chai, F.M., 2008. The association of mafic-ultramafic intrusions and A-type magmatism in the Tian Shan and Altay orogens, NW China: Implications for geodynamic evolution and potential for the discovery of new ore deposits. Journal of Asian Earth Sciences 32(2-4), 165-183.

Qin, K., Sun, S., Li, J., Fang, T., Wang, S., Liu, W., 2002. Paleozoic Epithermal Au and Porphyry Cu Deposits in North Xinjiang, China: Epochs, Features, Tectonic Linkage and Exploration Significance. Resource Geology 52(4), 291-300.

Ramos, V.A., Folguera, A., 2009. Andean flat-slab subduction through time. Geological Society, London, Special Publication 327(1), 31-54.

Rapp, R.P., Shimizu, N., Norman, M.D., Applegate, G.S., 1999. Reaction between slab-derived melts and peridotite in the mantle wedge: experimental constraints at $3.8 \mathrm{GPa}$. Chemical Geology 160(4), 335-356.

Rapp, R.P., Watson, E.B., 1995. Dehydration Melting of Metabasalt at 8-32 kbar: Implications for Continental Growth and Crust-Mantle Recycling. Journal of Petrology 36(4), 891-931.

Reich, M., Parada, M.A., Palacios, C., Dietrich, A., Schultz, F., Lehmann, B., 2003. Adakite-like signature of Late Miocene intrusions at the Los Pelambres giant porphyry copper deposit in the Andes of central Chile: metallogenic implications. Mineralium Deposita 38(7), 876-885.

Richards, J.P., Kerrich, R., 2007. Special Paper: Adakite-Like Rocks: Their Diverse Origins and Questionable Role in Metallogenesis. Economic Geology 102(4), 537-576.

Rivers, T., Corrigan, D., 2000. Convergent margin on southeastern Laurentia during the Mesoproterozoic: Tectonic implications. Canadian Journal of Earth Sciences 37(2-3), 359-383.

Seltmann, R., Porter, T.M., 20005. The porphyry $\mathrm{Cu}-\mathrm{Au} / \mathrm{Mo}$ deposits of Central Eurasia 1. Tectonic, geologic and metallogenic setting, and significant deposits. In: T.M. Porter (Editor), Super Porphyry Copper \& Gold Deposits: A Global Perspective. PGC Publishing, Adelaide, Australia, pp 467-512.

Sen, C., Dunn, T., 1994. Dehydration melting of a basaltic composition amphibolite at 1.5 and 2.0 GPa: implications for the origin of adakites. Contributions to Mineralogy and Petrology 117(4), 394-409.

[Insert Running title of $<72$ characters] 
1012

1013

1014

1015

1016

1017

1018

1019

1020

1021

1022

1023

1024

1025

1026

1027

1028

1029

1030

1031

1032

1033

1034

1035

1036

1037

1038

1039

1040

1041

1042

Sengör, A.M.C., Natal'in, B.A., Burtman, V.S., 1993. Evolution of the Altaid tectonic collage and Palaeozoic crustal growth in Eurasia. Nature 364(6435), 299-307.

Shu, L.S., Zhu, W.B., Wang, B., Faure, M., Charvet, J., Cluzel, D., 2005. The post-collision intracontinental rifting and olistostrome on the southern slope of Bogda Mountains, Xinjiang. Acta Petrologica Sinica 21(1), 25-36 (in Chinese with English abstract).

Stern, C.R., Kilian, R., 1996. Role of the subducted slab, mantle wedge and continental crust in the generation of adakites from the Andean Austral Volcanic Zone. Contributions to Mineralogy and Petrology 123(3), 263-281.

Streckeisen, A., Le Maitre, R.W., 1979. A chemical approximation to the modal QAPF classification of the igneous rocks. Neues Jahrbuch für Mineralogie, Abhandlungen 136, 169-206.

Sun, S.S., McDonough, W.F., 1989. Chemical and isotopic systematics of oceanic basalts: implications for mantle composition and processes. Geological Society London Special Publications 42(1), 313-345.

Tang, G.J., Wang, Q., Zhao, Z.H., Wyman, D.A., Chen, H.H., Jiang, Z.Q., Jia, X.H., 2009. LA-ICP-MS zircon U-Pb Geochronology, element geochemistry and petrogenesis of the andesites in the gold-mineralization area of the eastern Taerbieke, western Tianshan. Acta Petrologica Sinica 025(06), 1341-1352 (in Chinese with English abstract).

Tatsumi, Y., Eggins, S., 1995. Subduction zone magmatism. Blackwell Publishing, Boston.

Turner, S.P., Foden, J.D., Morrison, R.S., 1992. Derivation of some A-type magmas by fractionation of basaltic magma: An example from the Padthaway Ridge, South Australia. Lithos 28(2), 151-179.

Wang, B., Cluzel, D., Shu, L., Faure, M., Charvet, J., Chen, Y., Meffre, S., de Jong, K., 2009. Evolution of calc-alkaline to alkaline magmatism through Carboniferous convergence to Permian transcurrent tectonics, western Chinese Tianshan. International Journal of Earth Sciences 98(6), 1275-1298.

Wang, B., Faure, M., Cluzel, D., Shu, L., Charvet, J., Meffre, S., Qian, M., 2006a. Late Paleozoic tectonic evolution of the northern West Chinese Tianshan Belt. Geodinamica Acta 19(3-4), 227-237.

Wang, B., Shu, L.S., Cluzel, D., Faure, M., Charvet, J., 2007a. Geochemical constraints on Carboniferous volcanic rocks of the Yili Block (Xinjiang, NW China): Implication for

[Insert Running title of $<72$ characters] 
1043

1044

1045

1046

1047

1048

1049

1050

1051

1052

1053

1054

1055

1056

1057

1058

1059

1060

1061

1062

1063

1064

1065

1066

1067

1068

1069

1070

1071

1072

the tectonic evolution of Western Tianshan. Journal of Asian Earth Sciences 29(1), 148-159.

Wang, J.B., Xu, X., 2006. Post-collisional tectonic evolution and metallogenesis in Northern Xinjiang, China. Acta Geologica Sinica 80(1), 23-31(in Chinese with English Abstract).

Wang, Q., McDermott, F., Xu, J.F., Bellon, H., Zhu, Y.T., 2005. Cenozoic K-rich adakitic volcanic rocks in the Hohxil area, northern Tibet: Lower-crustal melting in an intracontinental setting. Geology 33(6), 465-468.

Wang, Q., Wyman, D.A., Xu, J., Jian, P., Zhao, Z., Li, C., Xu, W., Ma, J., He, B., 2007b. Early Cretaceous adakitic granites in the Northern Dabie Complex, central China: Implications for partial melting and delamination of thickened lower crust. Geochimica et Cosmochimica Acta 71(10), 2609-2636.

Wang, Q., Wyman, D.A., Zhao, Z.H., Xu, J.F., Bai, Z.H., Xiong, X.L., Dai, T.M., Li, C.F., Chu, Z.Y., 2007c. Petrogenesis of Carboniferous adakites and Nb-enriched arc basalts in the Alataw area, northern Tianshan Range (western China): Implications for Phanerozoic crustal growth in the Central Asia orogenic belt. Chemical Geology 236(1-2), 42-64.

Wang, Q., Xu, J.F., Jian, P., Bao, Z.W., Zhao, Z.H., Li, C.F., Xiong, X.L., Ma, J.L., 2006b. Petrogenesis of adakitic porphyries in an extensional tectonic setting, dexing, South China: Implications for the genesis of porphyry copper mineralization. Journal of Petrology 47(1), 119-144.

Wang, Q., Zhao, Z.H., Xu, J.F., Wyman, D.A., Xiong, X.L., Zi, F., Bai, Z.H., 2006c. Carboniferous adakite-high-Mg andesite-Nb-enriched basaltic rock suites in the Northern Tianshan area: Implications for Phanerozoic crustal growth in the Central Asia Orogenic Belt and $\mathrm{Cu}-\mathrm{Au}$ mineralization. Acta Petrologica Sinica 22(1), 11-30 (in Chinese with English abstract).

Wen, D.R., Liu, D., Chung, S.L., Chu, M.F., Ji, J.Q., Zhang, Q., Song, B., Lee, T.Y., Yeh, M.W., Lo, C.H., 2008. Zircon SHRIMP U-Pb ages of the Gangdese Batholith and implications for Neotethyan subduction in southern Tibet. Chemical Geology 252(3-4), 191-201.

Whalen, J.B., Currie, K.L., Chappell, B.W., 1987. A-type granites: geochemical characteristics, discrimination and petrogenesis. Contributions to Mineralogy and Petrology 95(4), 407-419.

[Insert Running title of $<72$ characters] 
1073

1074

1075

1076

1077

1078

1079

1080

1081

1082

1083

1084

1085

1086

1087

1088

1089

1090

1091

1092

1093

1094

1095

1096

1097

1098

1099

1100

1101

1102

1103

Whalen, J.B., McNicoll, V.J., van Staal, C.R., Lissenberg, C.J., Longstaffe, F.J., Jenner, G.A., van Breeman, O., 2006. Spatial, temporal and geochemical characteristics of Silurian collision-zone magmatism, Newfoundland Appalachians: An example of a rapidly evolving magmatic system related to slab break-off. Lithos 89(3-4), 377-404.

Whalen, J.B., Wodicka, N., Taylor, B.E., Jackson, G.D., 2010. Cumberland batholith, Trans-Hudson Orogen, Canada: Petrogenesis and implications for Paleoproterozoic crustal and orogenic processes. Lithos 117(1-4), 99-118.

Winchester, J.A., Floys, P.A., 1977. Geochemical discrimination of different magma series and their differentiation products using immobile elements. Chemical Geology 20, 325-343.

Windley, B.F., Allen, M.B., Zhang, C., Zhao, Z.Y., Wang, G.R., 1990. Paleozoic accretion and Cenozoic redeformation of the Chinese Tien Shan Range, Central Asia. Geology 18(2), 128-131.

Wu, F.Y., Jahn, B.M., Wilde, S.A., Lo, C.H., Yui, T.F., Lin, Q., Ge, W.C., Sun, D. Y., 2003. Highly fractionated I-type granites in NE China (II): Isotopic geochemistry and implications for crustal growth in the Phanerozoic. Lithos 67, 191-204.

Wu, F.Y., Sun, D.Y., Li, H.M., Jahn, B.M., Wilde, S., 2002. A-type granites in northeastern China: age and geochemical constraints on their petrogenesis. Chemical Geology 187(1-2), 143-173.

XBGMR (Xinjiang Bureau of Geology and Mineral Resources), 1993. Regional geology of Xinjiang Uygur Autonomy Region. Geology Publishing House, Beijing, pp 841.

Xia, L.Q., Xu, X.Y., Xia, Z.C., Li, X.M., Ma, Z.P., Wang, L.S., 2004a. Petrogenesis of Carboniferous rift-related volcanic rocks in the Tianshan, northwestern China. Geological Society of America Bulletin 116(3-4), 419-433.

Xia, L.Q., Xia, Z.C., Xu, X.Y., Li, X.M., Ma, Z.P., Wang, L.S., 2004b. Carboniferous Tianshan igneous megaprovince and mantle plume. Geologcal Bulletin of China 23(9), 903-910 (in Chinese with English abstract).

Xiao, L., Clemens, J.D., 2007. Origin of potassic (C-type) adakite magmas: Experimental and field constraints. Lithos 95(3-4), 399-414.

Xiao, L., Nick, H., Graham, B., Fu, M., Wang, F.Z., Franco, P., 2005. The Jinxi-Yelmand high-sulfidation epithermal gold deposit, Western Tianshan, Xinjiang Province, P.R. China. Ore Geology Reviews 26(1-2), 17-37.

[Insert Running title of $<72$ characters] 
1104

1105

1106

1107

1108

1109

1110

1111

1112

1113

1114

1115

1116

1117

1118

1119

1120

1121

1122

1123

1124

1125

1126

1127

1128

1129

1130

1131

1132

1133

Xiao, W.J., Han, C.M., Yuan, C., Sun, M., Lin, S.F., Chen, H.L., Li, Z.L., Li, J.L., Sun, S., 2008. Middle Cambrian to Permian subduction-related accretionary orogenesis of Northern Xinjiang, NW China: Implications for the tectonic evolution of central Asia. Journal of Asian Earth Sciences 32(2-4), 102-117.

Xiao, W.J., Windley, B.F., Yuan, C., Sun, M., Han, C.M., Lin, S.F., Chen, H.L., Yan, Q.R., Liu, D.Y., Qin, K.Z., Li, J.L., Sun, S., 2009. Paleozoic multiple subduction-accretion processes of the southern Altaids. American Journal of Science 309(3), 221-270.

Xiao, W.J., Zhang, L.C., Qin, K.Z., Sun, S., Li, J.L., 2004. Paleozoic accretionary and collisional tectonics of the eastern Tianshan (China): Implications for the continental growth of central Asia. American Journal of Science 304(4), 370-395.

Xiao, X.C., Tang, Y.Q., Li, J.Y., Zhao, M., Feng, Y.M., Zhu, B.Q., 1991. On tectonic evolution of the southern margin of the Paleozoic composite megasuture zone. In: X.C. Xiao and Y.Q. Tang (Editors), On Tectonic Evolution of the Southern Margin of the Paleozoic Composite Megasuture Zone. Beijing Technology Press, Beijing, pp. 1-29 (in Chinese).

Xiao, Y.L., Sun, W.D., Hoefs, J., Simon, K., Zhang, Z.M., Li, S.G., Hofmann, A.W., 2006, Making continental crust through slab melting: Constraints from niobium-tantalum fractionation in UHP metamorphic rutile: Geochimica Et Cosmochimica Acta 70, 4770-4782.

Xu, J.F., Shinjo, R., Defant, M.J., Wang, Q.A., Rapp, R.P., 2002. Origin of Mesozoic adakitic intrusive rocks in the Ningzhen area of east China: Partial melting of delaminated lower continental crust? Geology 30(12), 1111-1114.

Xu, X.Y., Li, X.M., Ma, Z.P., Xia, L.Q., Xia, Z.C., Peng, S.X., 2006a. LA-ICPMS Zircon U-Pb dating of gabbro from the Bayingou Ophiolite in the Northern Tianshan Mountains. Acta Geologica Sinica 80(8), 1168-1176 (in Chinese with English abstract).

Xu, X.Y., Ma, Z.P., Xia, Z.C., Xia, L.Q., Li, X.M., Wang, L.S., 2006b. TIMS U-Pb Isotopic Dating and Geochemical Characteristics of Paleozoic Granitic Rocks from the Middle-Western Section of Tianshan. Northwestern Geology 39(1), 50-75 (in Chinese with English abstract).

Yakubchuk, A., 2004. Architecture and mineral deposit settings of the Altaid orogenic collage: a revised model. Journal of Asian Earth Sciences 23(5), 761-779.

[Insert Running title of $<72$ characters] 
1134

1135

1136

1137

1138

1139

1140

1141

1142

1143

1144

1145

1146

1147

1148

1149

1150

1151

1152

1153

1154

1155

1156

1157

1158

1159

1160

1161

1162

1163

Yang, J.H., Wu, F.Y., Chung, S.L., Wilde, S.A., Chu, M.F., 2006. A hybrid origin for the Qianshan A-type granite, northeast China: Geochemical and Sr-Nd-Hf isotopic evidence. Lithos 89(1-2), 89-106.

Yin, J., Yuan, C., Sun, M., Long, X., Zhao, G., Wong, K.P., Geng, H., Cai, K., 2009. Late Carboniferous high-Mg dioritic dikes in Western Junggar, NW China: Geochemical features, petrogenesis and tectonic implications. Gondwana Research 17(1), 145-152.

Zhai, W., Sun, X.M., Gao, J., He, X.P., Liang, J.L., Miao, L.C., Wu, Y.L., 2006. SHRIMP dating of zircons from volcanic host rocks of Dahalajunshan Formation in Axi gold deposit, Xinjiang, China, and its geological implications. Acta Petrologica Sinica 22(5), 1399-1404 (in Chinese with English abstract).

Zhai, W., Sun, X.M., Sun, W.D., Su, L.W., He, X.P., Wu, Y.L., 2009. Geology, geochemistry, and genesis of Axi: A Paleozoic low-sulfidation type epithermal gold deposit in Xinjiang, China, Ore Geology Reviews 36(04), 265-281.

Zhang, D.Y., Zhang, Z.C., Ai, Y., Su, H.M., 2009. Geochronology, geochemistry of the Ores-Bearing Porphyries in the Lailisigao'er Region, Western Tianshan: implications for their tectonic setting and mineralization. Acta Petrologica Sinica 025(06), 1319-1331 (in Chinese with English abstract).

Zhang, H.F., Parrish, R., Zhang, L., Xu, W.C., Yuan, H.L., Gao, S., Crowley, Q.G., 2007. A-type granite and adakitic magmatism association in Songpan-Garze fold belt, eastern Tibetan Plateau: Implication for lithospheric delamination. Lithos 97(3-4), 323-335.

Zhang, L.C., Xiao, W.J., Qin, K.Z., Zhang, Q., 2006a. The adakite connection of the Tuwu-Yandong copper porphyry belt, eastern Tianshan, NW China: trace element and $\mathrm{Sr}-\mathrm{Nd}-\mathrm{Pb}$ isotope geochemistry. Mineralium Deposita 41(2), 188-200.

Zhang, Y.P., Wang, R., Wang, D.G., 2008a. Kekesai granite diorite-porphyry body zircon SHRIMP U-Pb dating and the prospecting significance in Bole city, Xinjiang. Xinjiang Geology 26(4), 340-342 (in Chinese with English abstract).

Zhang, Z.H., Mao, J.W., Wang, Z.L., Du, A.D., Wang, L.S., Wang, J.W., Qu.W.J, 2006 b. Geology and metallogenetic epoch of the Dabate Porphyry Copper Deposit in West Tianshan Mountains, Xinjiang. Geological Review 52(5), 683-689 (in Chinese with English abstract).

[Insert Running title of $<72$ characters] 
1164 Zhang, Z.H., Wang, Z.L., Du, A.D., Zuo, G.C., Liu, M., Wang, L.S., Wang, J.W., 2008b. Tectonic setting of the volcanic rocks in Dabate district and their Constraints on the ore-forming of porphyry ore, West Tianshan Mountains. Acta Geologica Sinica 82(11), 1494-1503 (in Chinese with English abstract).

Zhang, Z.H., Wang, Z.L., Wang, L.S., Zuo, G.C., 2008c. Metallogenic epoch and ore-forming environment of the Lamasu skarn-porphyritic $\mathrm{Cu}-\mathrm{Zn}$ deposot, Western Tianshan, Xinjiang, NW China. Acta Geologica Sinica 82(4), 731-740 (in Chinese with English abstract).

Zhao, Z., Mo, X., Dilek, Y., Niu, Y., DePaolo, D.J., Robinson, P., Zhu, D., Sun, C., Dong, G., Zhou, S., Luo, Z., Hou, Z., 2009. Geochemical and Sr-Nd-Pb-O isotopic compositions of the post-collisional ultrapotassic magmatism in SW Tibet: Petrogenesis and implications for India intra-continental subduction beneath southern Tibet. Lithos 113(1-2), 190-212.

Zhou, M.F., Michael Lesher, C., Yang, Z.G., Li, J.W., Sun, M., 2004. Geochemistry and petrogenesis of $270 \mathrm{Ma} \mathrm{Ni-Cu-(PGE)} \mathrm{sulfide-bearing} \mathrm{mafic} \mathrm{intrusions} \mathrm{in} \mathrm{the} \mathrm{Huangshan}$ district, Eastern Xinjiang, Northwest China: implications for the tectonic evolution of the Central Asian orogenic belt. Chemical Geology 209(3-4), 233-257. from Carboniferous intrusive rocks on the active continental margin of Eren Habirga, West Tianshan, Xinjiang, China, and its geological implications. Geologcal Bulletin of China 25(8), 986-991(in Chinese with English abstract). 

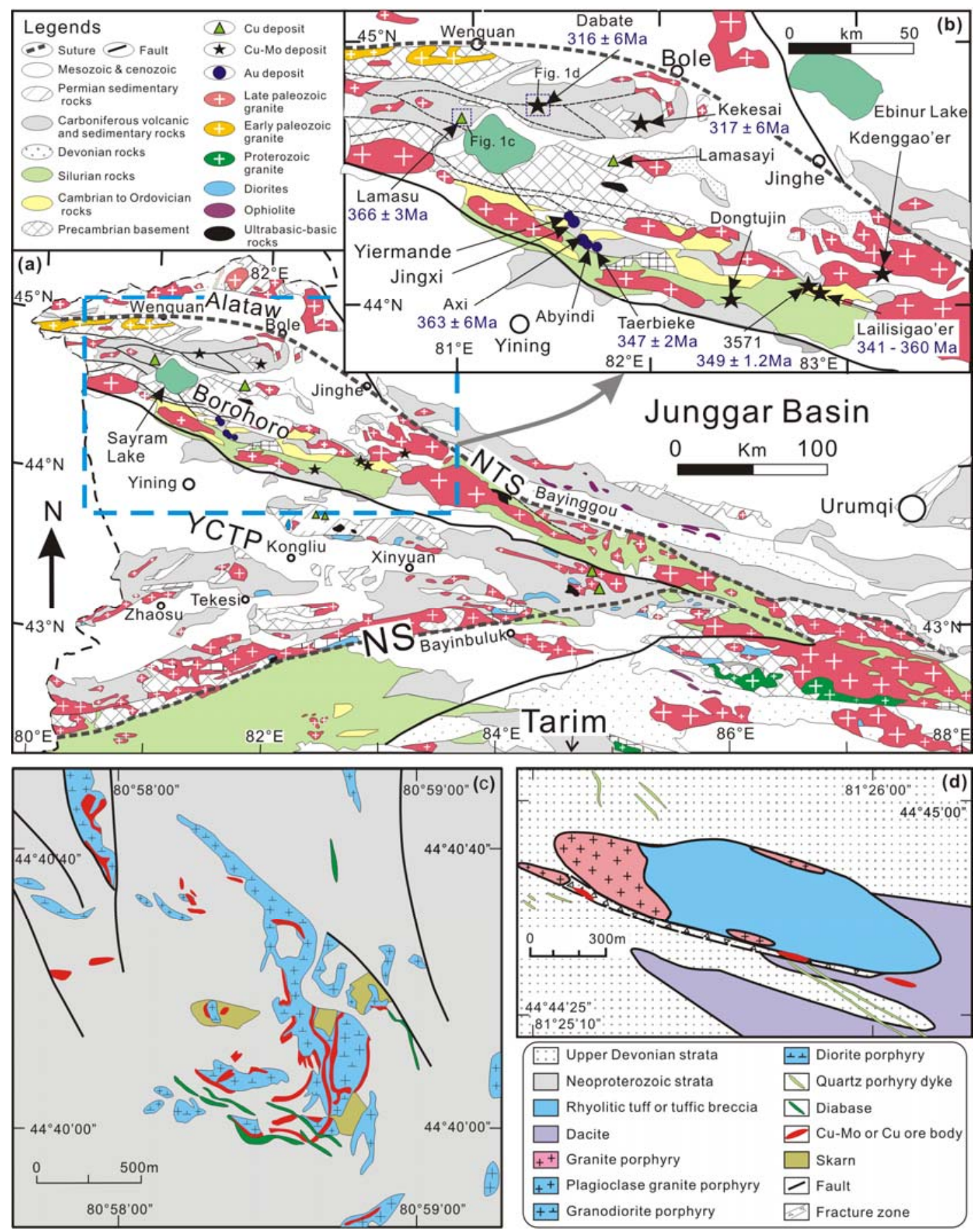

Fig. 1. Geological map of the northwestern Tianshan (west China) showing the location of

1189 porphyry copper and epithermal gold deposits (modified from Xinjiang Bureau of Geology and

1190 Mineral Resources (XBGMR, 1993). The age data for the Cu-Mo-Au deposits are from Li et al.

[Insert Running title of $<72$ characters] 
1191 (2006), Zhai et al. (2006), Zhang et al. (2008b, 2009), Tang et al. (2009) and this study. YCTP1192 Yili-Central Tianshan plate. NTS-North Tianshan Suture: the boundary between the Junggar and 1193 Yili-Central Tianshan Plates; NS-Nalati Suture: the boundary between the Yili-Central Tianshan 1194 and Tarim plates. 

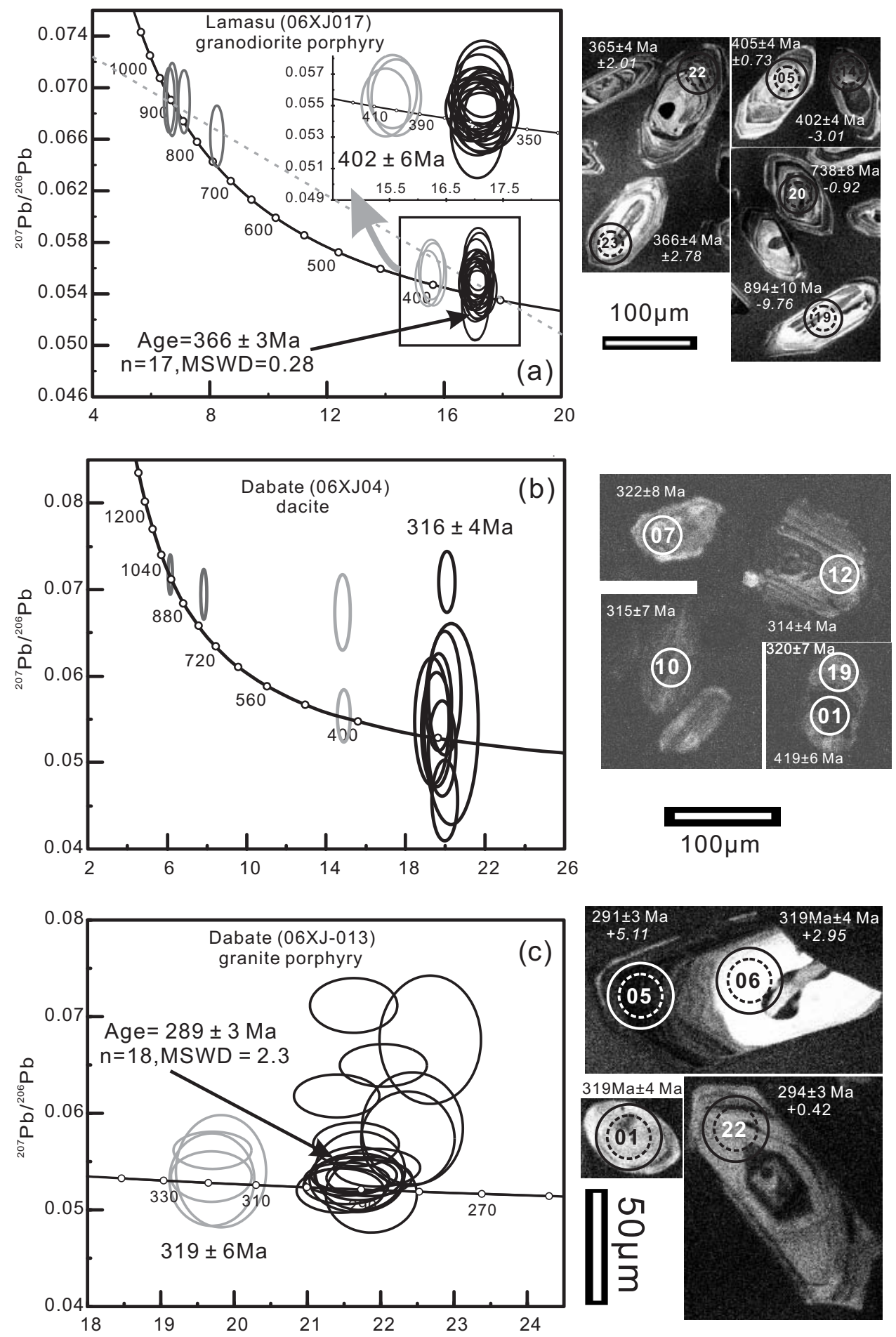

1197 Fig. 2. LA-ICP-MS U-Pb zircon Tera-Wasserburg diagrams with cathodoluminescence images 1198 for (a) a granodiorite porphyry and a dacite and a granite porphyry (b-c) from the Lamasu and 1199 Dabate areas, respectively. Dashed and solid line circles indicate the locations of age and Hf [Insert Running title of $<72$ characters] 

age and $\varepsilon \mathrm{Hf}(\mathrm{t})$ values for each spot are given.

1202
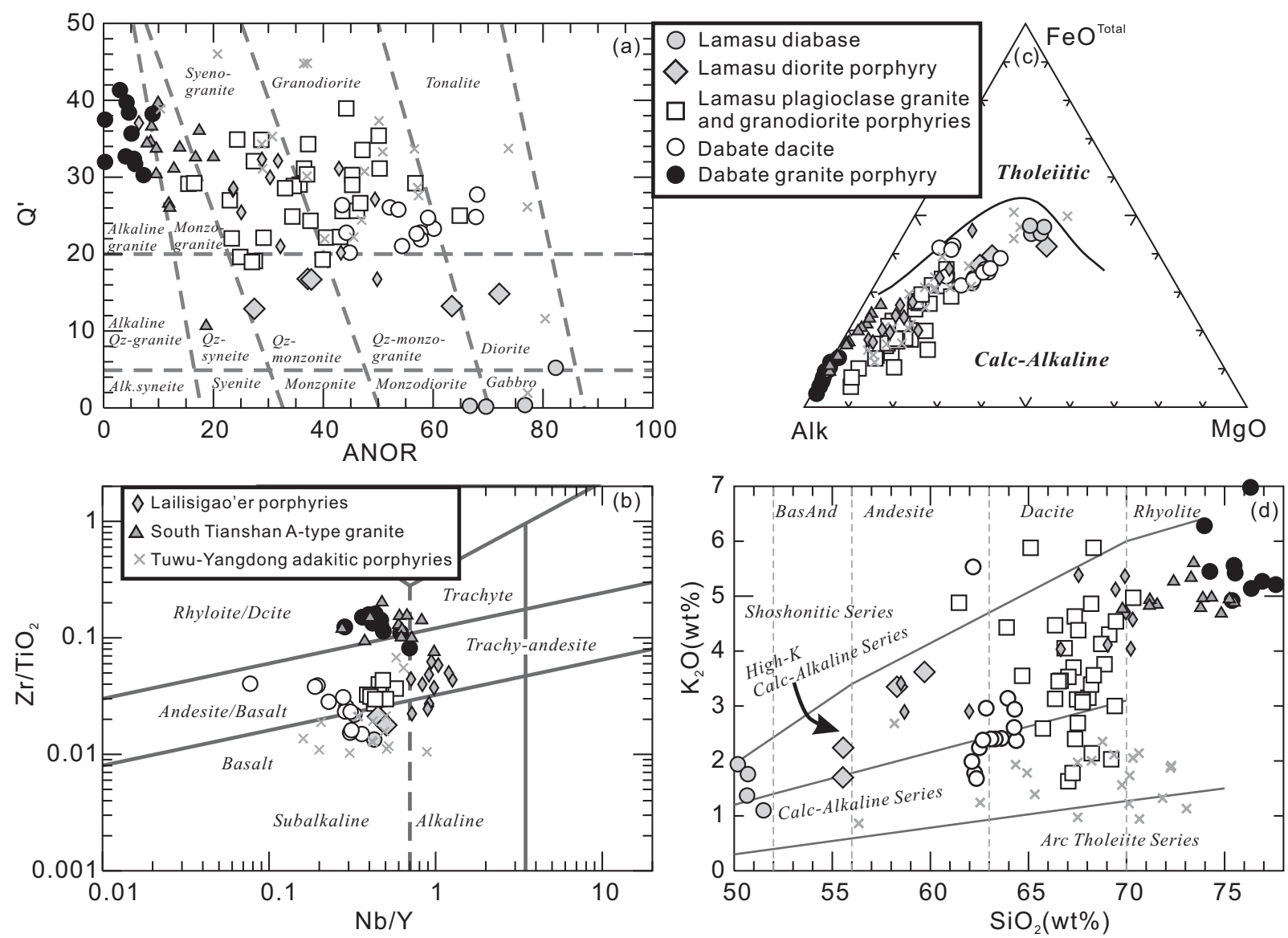

Fig. 3. (a) Q'-ANOR normative composition diagram (Streckeisen and Le Maitre, 1979). (b) $\mathrm{Zr} / \mathrm{TiO}_{2}-\mathrm{Nb} / \mathrm{Y}$ discrimination diagram (Winchester and Floys, 1977). (c) AFM plot (Irvine and Baragar, 1971). (d) $\mathrm{SiO}_{2}-\mathrm{K}_{2} \mathrm{O}$ plot (Peccerillo and Taylor, 1976). Data for the Lamasu samples are from Appendix 3 and Guan et al., (1990). Data for the Dabate samples are from Appendix 3 and Zhang et al., (2008b). Data for Lailisigao'er porphyries are from Zhang et al.,(2009). The south Tianshan A-type granites are from Konopelko et al.,(2007). The Tuwu-Yandong porphyries are from Zhang ea al., (2006a) and reference therein. 
[First Authors Last Name] Page 45
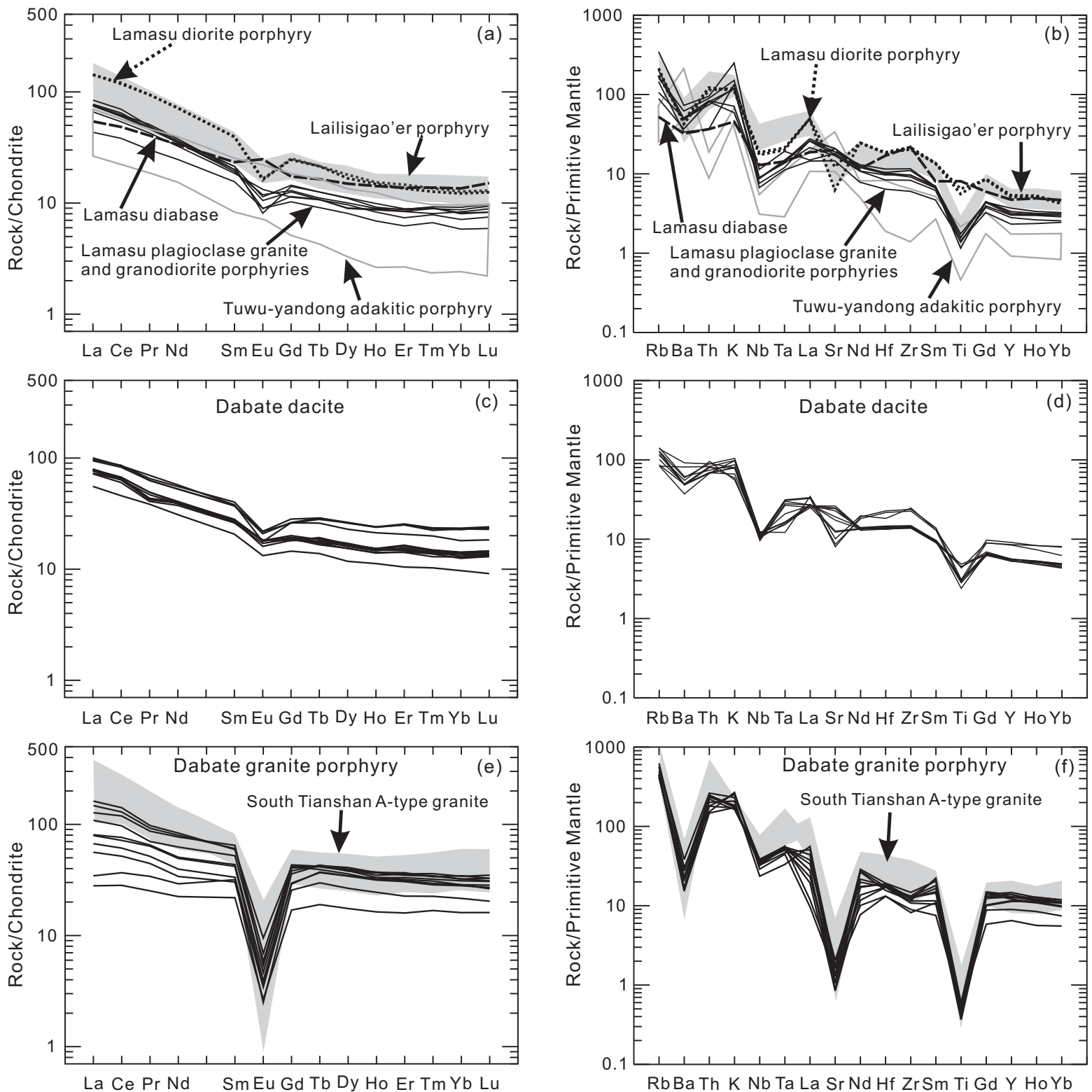

1213 Fig. 4. Chondrite-normalized REE patterns (a, c, e) and primitive mantle normalized trace

1214 elements diagrams (b, $d, f)$ for Lamasu and Dabate samples from the NTOB compared with the

1215 Lailisigao'er and Tuwu-Yandong porphyries and the South Tianshan A-type granites (Data 1216 sources as for Fig. 3). Chondrite and primitive mantle normalized values are from Sun and 1217 McDonough (1989). 
[First Authors Last Name] Page 46
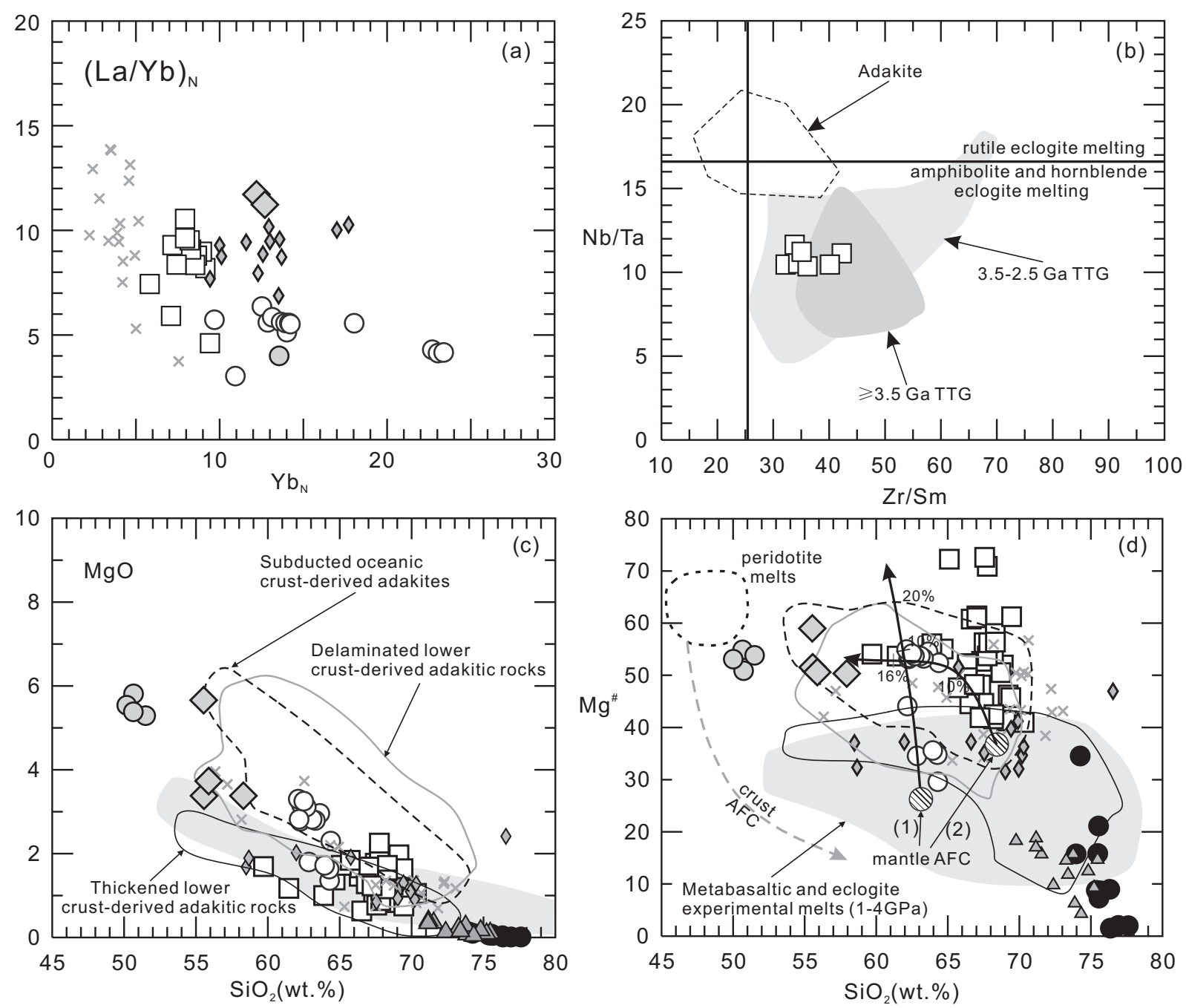

Fig. 5. (a) $\mathrm{Yb}_{\mathrm{N}}$ versus $(\mathrm{La} / \mathrm{Yb})_{\mathrm{N}}$ diagram. (b) $\mathrm{Nb} / \mathrm{Ta}$ versus $\mathrm{Zr} / \mathrm{Sm}$ diagram (Foley et al., 2002).

(c) $\mathrm{SiO}_{2}$ versus $\mathrm{MgO}$ diagram. (d) $\mathrm{SiO}_{2}$ versus $\mathrm{Mg}^{\#}$ diagram. Mantle $\mathrm{AFC}$ curves, with

1222 proportions of assimilated peridotite indicated, are after Stern and Kilian (1996) (Curve 1) and

1223 Rapp et al., (1999) (Curve 2), peridotite melts and crust AFC curves from Stern and Kilian

1224 (1996). Data for metabasaltic and eclogite experimental melts (1-4.0 GPa), and

1225 peridotite-hybridized equivalents, are from Rapp et al., (1999) and references therein. The field for subducted oceanic crust-derived adakites, and delaminated or thickened lower crust-derived adakitic rocks after Wang et al. (2006). Data sources and symbols are same as in Fig. 3. 
[First Authors Last Name] Page 47
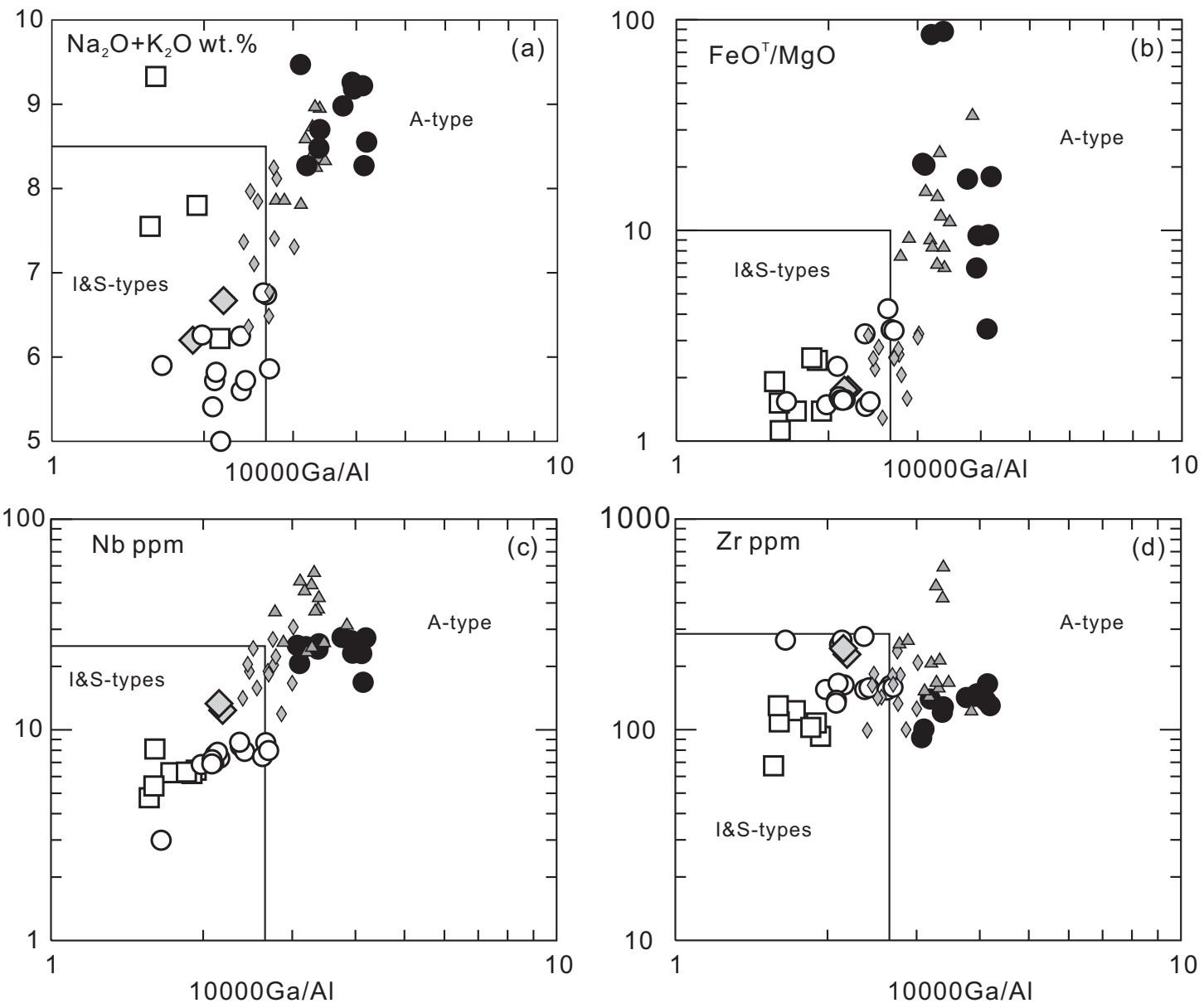

1230 Fig. 6. Discrimination diagrams for A-type granites (Whalen et al., 1987). Dabate granitic 1231 porphyries plot in the field of A-type granite. Other magmatic rock samples are plotted for 1232 comparison. Data sources and symbols are the same as in Fig. 3.

[Insert Running title of $<72$ characters] 
[First Authors Last Name] Page 48
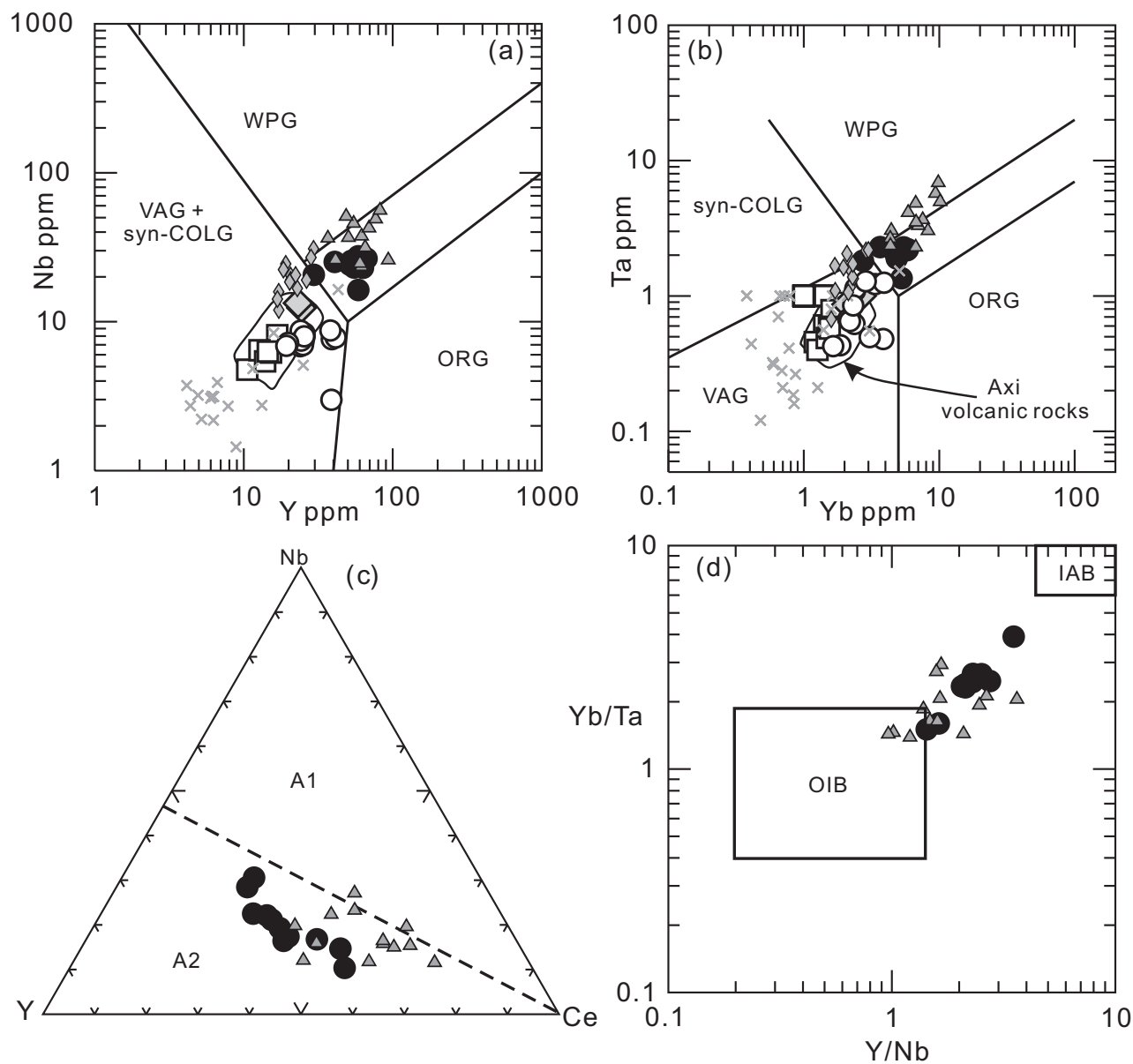

1235 Fig. 7. Tectonic discrimination plot for granites (a and b) (Pearce et al., 1984). (c) $A_{1}$ and $A_{2}$ 1236 subgroup discrimination of A-type granites and (d) $\mathrm{Y} / \mathrm{Nb}$ versus $\mathrm{Yb} / \mathrm{Ta}$ diagram for Dabate 1237 granitic porphyry (Eby, 1992). Data sources and symbols are same as in Fig. 3. 
[First Authors Last Name] Page 49
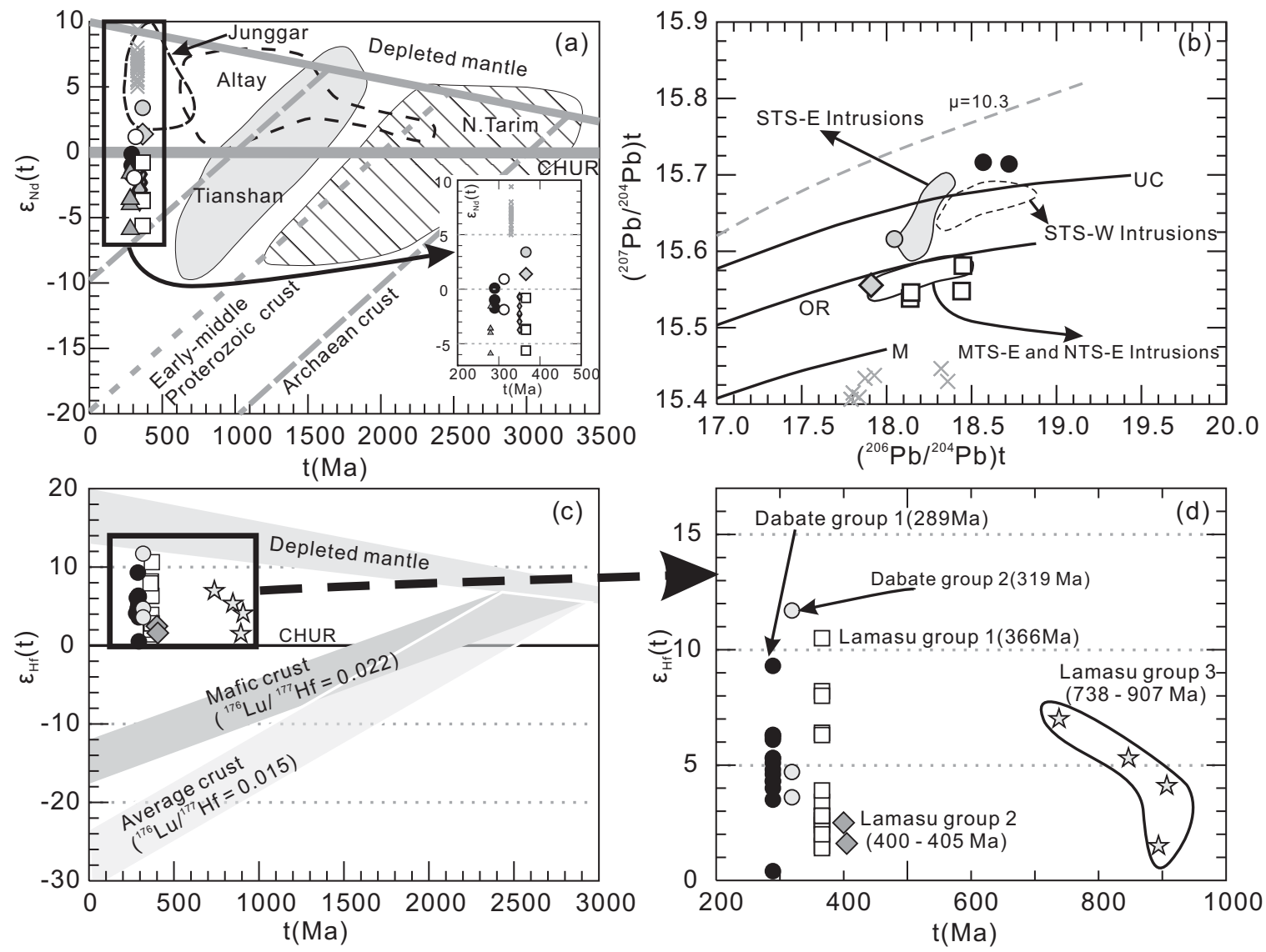

Fig. 8. $\varepsilon_{\mathrm{Nd}}(\mathrm{t})$ and $\varepsilon_{\mathrm{Hf}}(\mathrm{t})$ versus age diagram (a, $\mathrm{c}$ and $\mathrm{d}$ ). Fields of basement rocks (amphibolites 1241 and gneisses) of the Junggar, Altay and Tianshan are from Hu et al. (2000). (b) $\left({ }^{206} \mathrm{~Pb} /{ }^{204} \mathrm{~Pb}\right)_{\mathrm{t}}$ 1242 versus $\left({ }^{207} \mathrm{~Pb} /{ }^{204} \mathrm{~Pb}\right)_{\mathrm{t}}$ diagram. Field of Tianshan (TS) intrusions are from Massimo et al. (2006).

1243 Data sources are from Appendix 4 and 5. Symbols are same as in Fig. 3.

[Insert Running title of $<72$ characters] 
[First Authors Last Name] Page 50
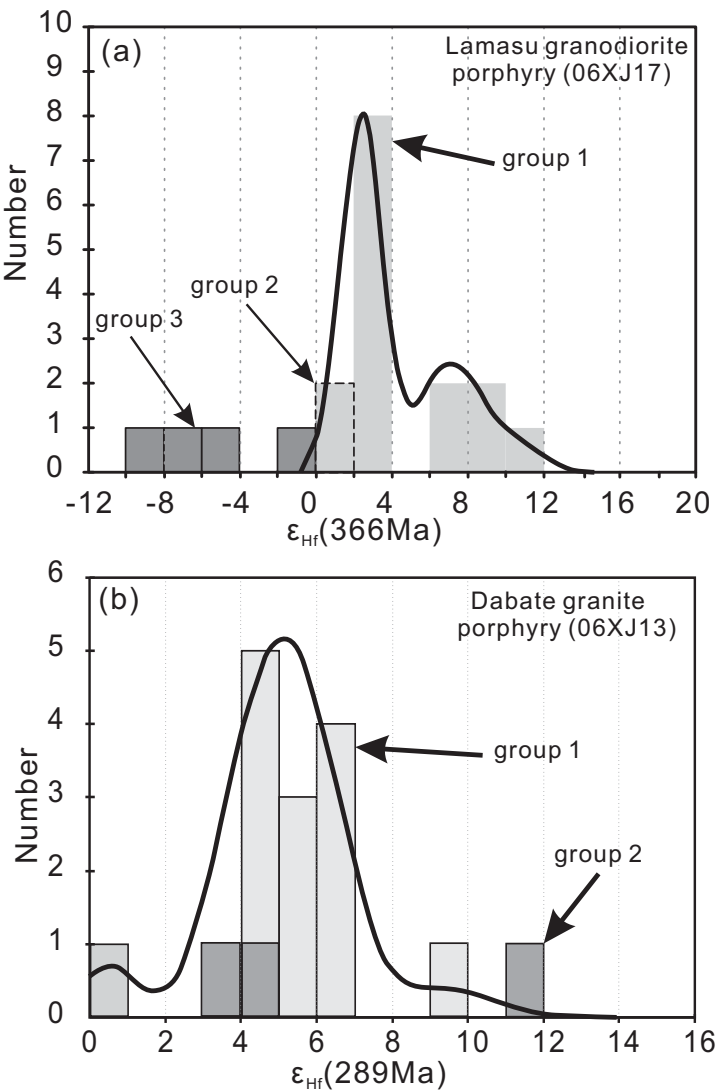

Fig. 9. Histogram of $\varepsilon_{\mathrm{Hf}}(\mathrm{t})$ values for the Lamasu granodiorite porphyry (a) and the Dabate granite (b). Data sources are from Appendix 5.

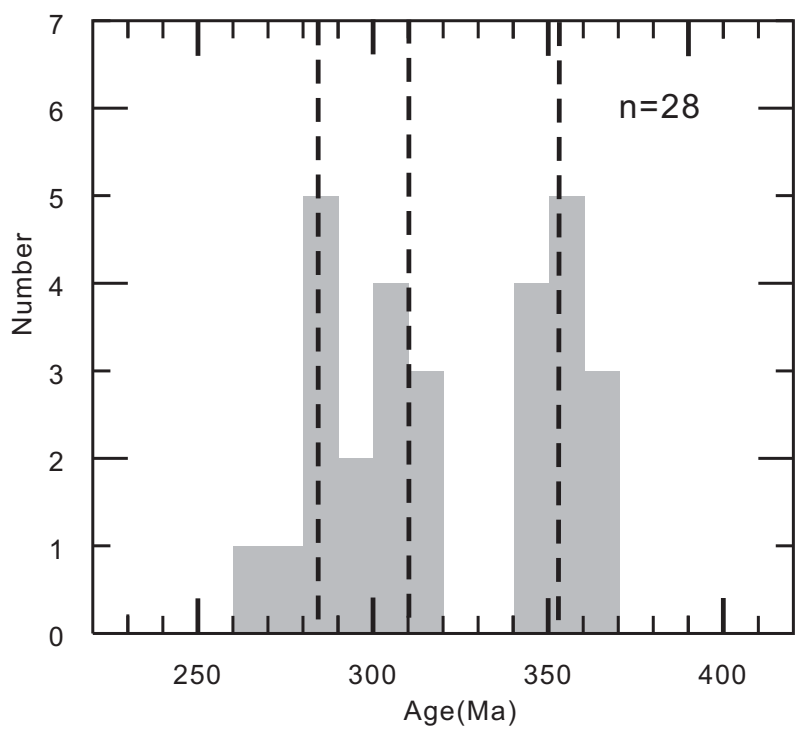

1250 Fig. 10. Histograms of ages for the igneous rocks in the NTOB. Data sources: Li et al., 2006;

1251 Wang et al., 2009, 2007a, 2007c; Xu et al., 2006b; Zhai et al., 2006; Zhang et al., 2009, 2008a;, [Insert Running title of $<72$ characters] 

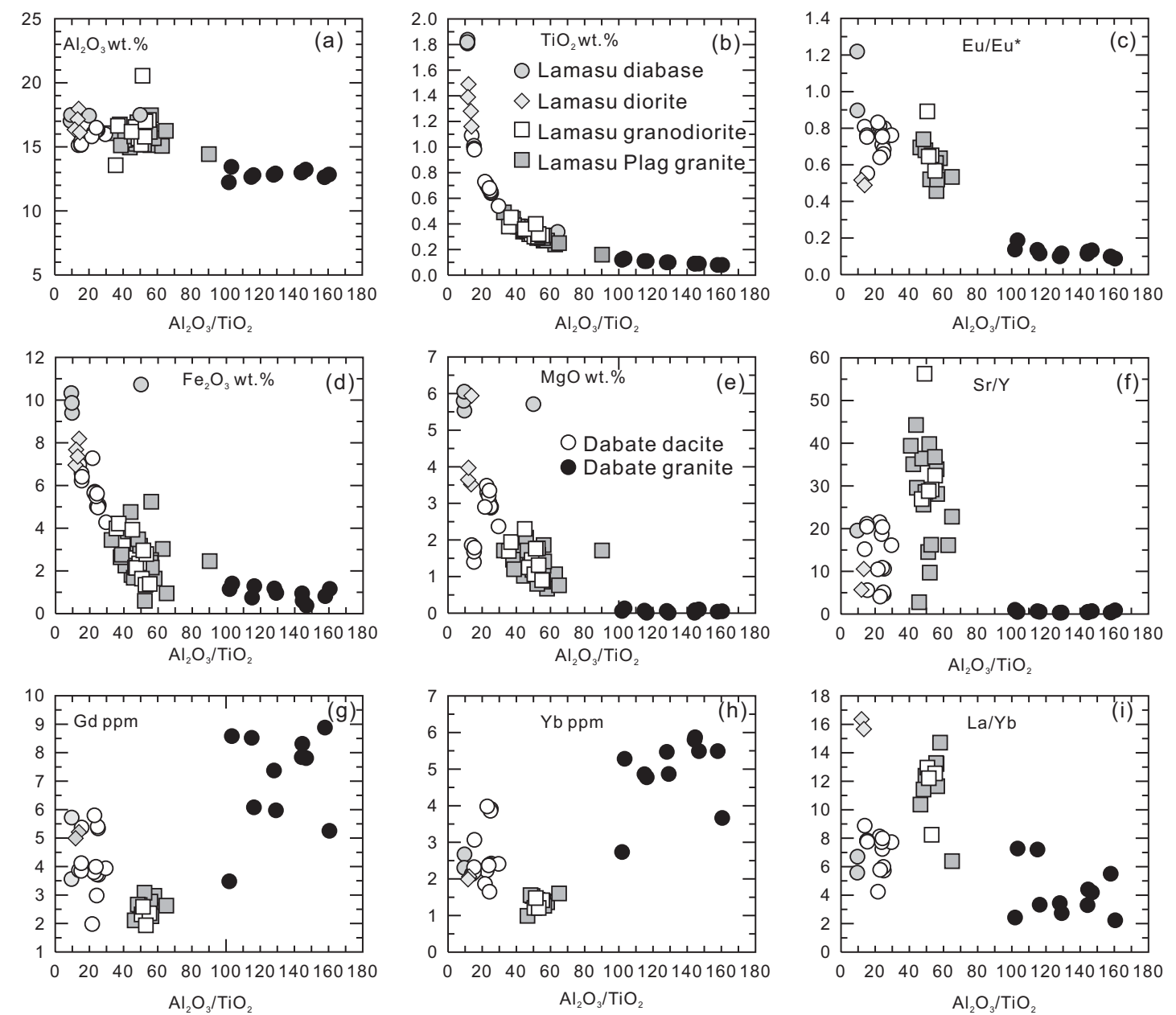

Fig. 11. $\mathrm{Al}_{2} \mathrm{O}_{3} / \mathrm{TiO}_{2}$ versus $\mathrm{Al}_{2} \mathrm{O}_{3}$

(a), $\mathrm{TiO}_{2}(\mathrm{~b}), \mathrm{Eu} / \mathrm{Eu}^{*}(\mathrm{c})$

(c), $\mathrm{Fe}_{2} \mathrm{O}_{3}$

(d), $\mathrm{MgO}$

$(\mathrm{e}), \mathrm{Yb}$

(f), Gd (g), $\mathrm{Sr} / \mathrm{Y}$, and $\mathrm{La} / \mathrm{Yb}$ (i). Data sources are same as in Fig. 3.

[Insert Running title of $<72$ characters] 
[First Authors Last Name] Page 52
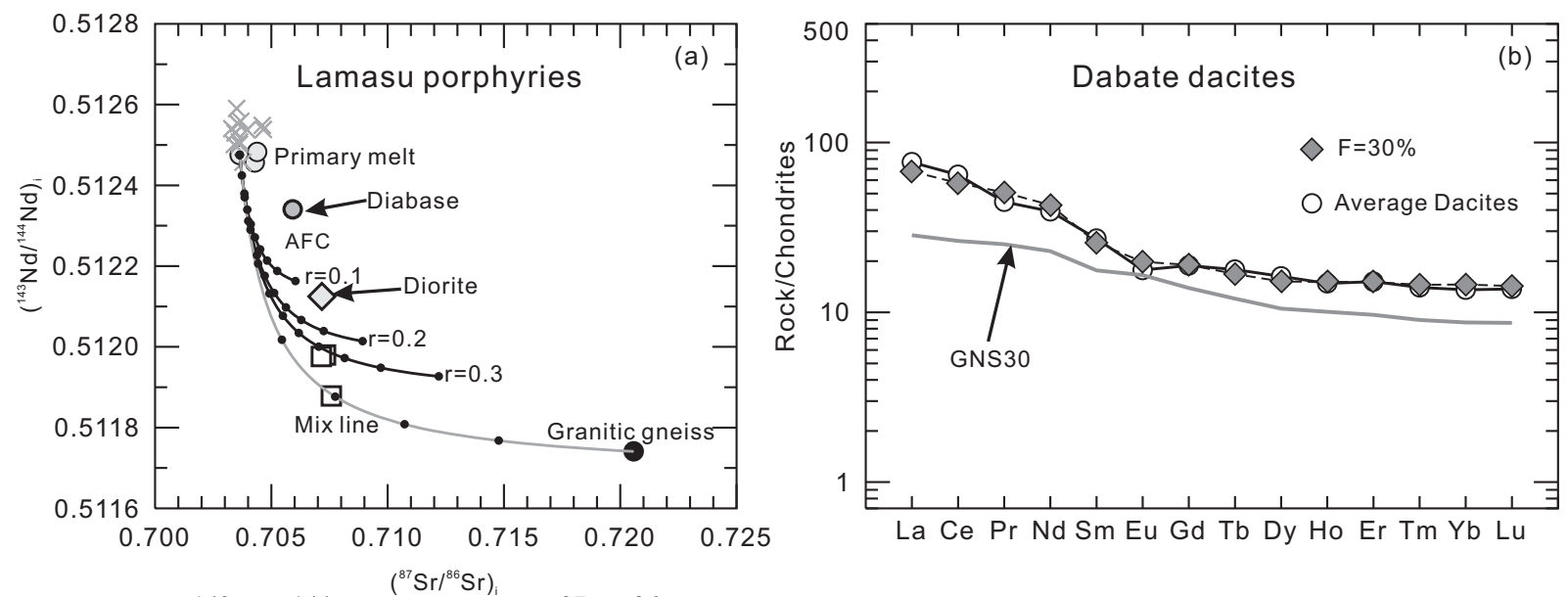

Fig. 12. $\left({ }^{143} \mathrm{Nd} /{ }^{144} \mathrm{Nd}\right)_{\mathrm{i}}$ versus $\left({ }^{87} \mathrm{Sr} /{ }^{86} \mathrm{Sr}\right)_{\mathrm{i}}$ plot showing two-component mixing and $\mathrm{AFC}$

1260 calculations for Lamasu porphyries. For AFC trends with $r=0.1,0.2$ and 0.3 , symbols represent

1261 fraction of melt $(\mathrm{F})$ increments of 0.2 but are terminated at $\mathrm{F}=0.1$. Primary melt from a gabbro

1262 sample in the Bayingou ophiolites (Xu et al., 2006a). Data for granitic gneiss of basement rock,

1263 southern Wenquan city are form $\mathrm{Hu}$ et al. (2000). The bulk partition coefficient for $\mathrm{Sr}$ and $\mathrm{Nd}$ is

12641.12 and 0.13, respectively. (b) REE modeling patterns for Dabate dacites showing melt curves

1265 by batch partial melting. The partial coefficients for REEs are from McKenzie and O'Nions, 1266 (1991). 
(a) Late Ordovician-Early Carboniferous (455-345 Ma)

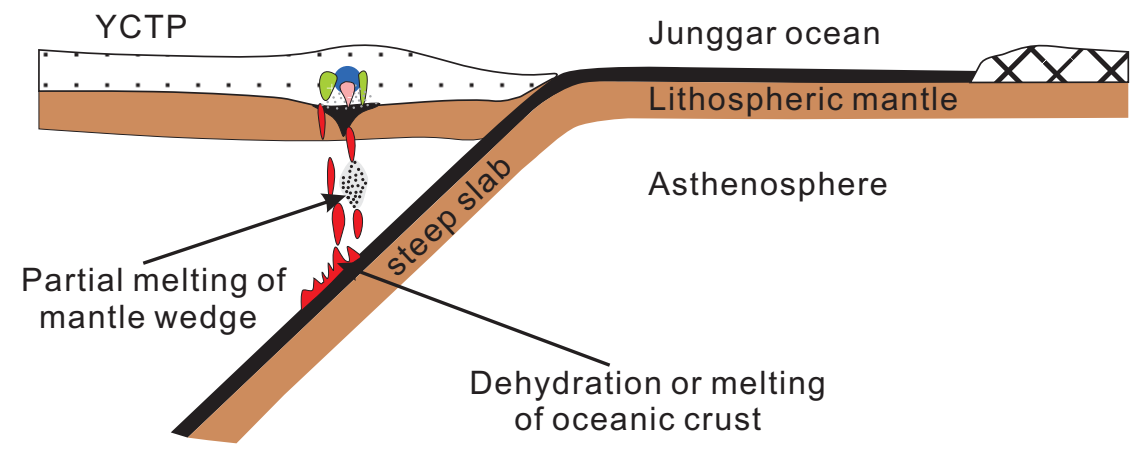

(b) Middle Carboniferous (345-320 Ma)

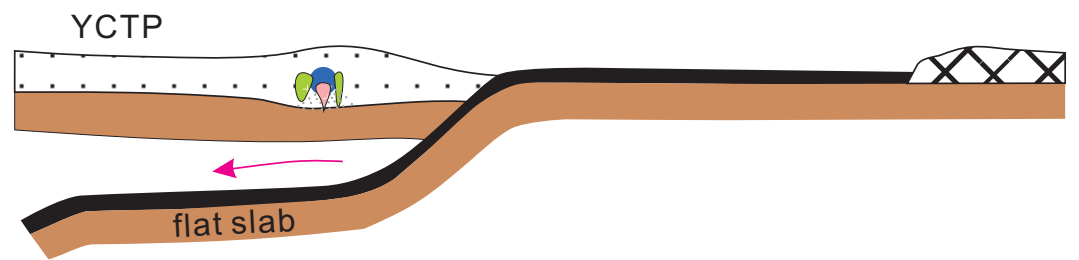

(c) Late Carboniferous (317-306 Ma)

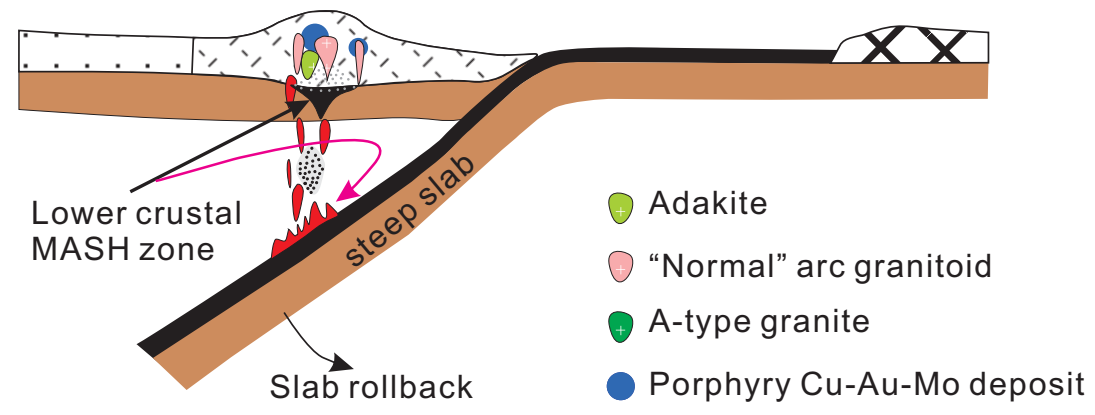

(d) Early Permian (300-280 Ma)

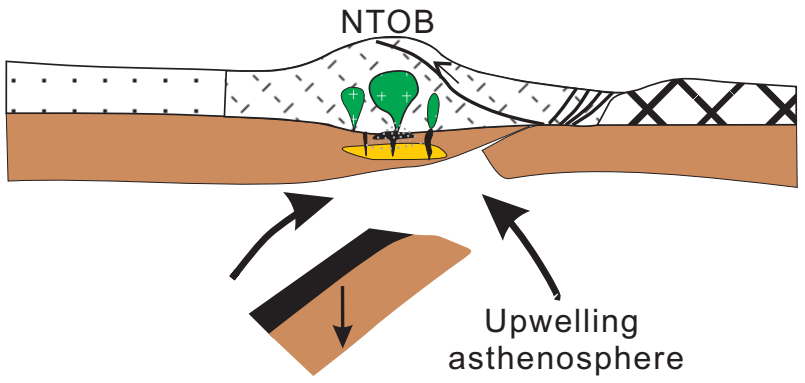

1269 Fig. 13. A suggested model to produce the Late Paleozoic igneous rocks and $\mathrm{Cu}-\mathrm{Au}-\mathrm{Mo}$ deposits 1270 from the northwestern Tianshan Orogenic Belt (NTOB). (a) The Junggar Ocean southward 1271 subducted beneath the Yili-Central Tianshan plate (YCTP) as early as the Late Ordovician ( [Insert Running title of $<72$ characters] 
$1272455 \mathrm{Ma}$ ), and forming the northwestern Tianshan magmatism arc from the Late Devonian to

1273 Early Carboniferous (366-345 Ma). We have shown above that the most primitive members of 1274 the Lamasu suite already possessed adakitic geochemical traits, and did not acquire them through 1275 the AFC processes. Partial melts of subducted oceanic crust-derived adakitic magmas (e.g., the 1276 Lamasu intrusive rocks) are considered to be favorable for the generation of porphyry $\mathrm{Cu}-\mathrm{Au}$ and 1277 hydrothermal ore deposits as suggested by many workers (e.g., Defant and Kepezhinskas, 2001; 1278 Defant et al., 2002; Mungall, 2002; Wang et al., 2006b). (b) flat-subduction with little or no 1279 magmatism. (c) Transition from flat to normal slab subduction owing to slab rollback. A Late 1280 Carboniferous magmatic arc formed (317-306 Ma) and was also related to the southward 1281 subduction of the Junggar Ocean beneath the YCTP. During this process, multiple factors, such 1282 as an arc tectonic setting, relatively oxidized magmas, and AFC - mixing processes at the base of 1283 the crust are significant in the generation of giant calc-alkaline porphyry deposits. (d) Slab 1284 breakoff: post-collisional environments in the Early Permian NTOB following the disappearance 1285 of the Junggar Ocean. 
[First Authors Last Name] Page 55

\section{Appendices}

1291 Appendix 1 Analytical methods

1292 Zircons were separated using conventional heavy liquid and magnetic separation techniques.

1293 Cathodoluminescence (CL) images were obtained for zircons prior to analysis, using a JEOL

1294 JXA-8100 Superprobe at the Guangzhou Institute of Geochemistry, Chinese Academy of 1295 Sciences (GIGCAS), in order to characterize internal structures and choose potential target sites 1296 for U-Pb dating. LA-ICP-MS zircon U-Pb analyses were conducted on an Agilent 7500 ICP-MS 1297 equipped with a 193-nm laser, housed at the State Key Laboratory of Geological Processes and 1298 Mineral Resources, Faculty of Earth Sciences, China University of Geosciences (Wuhan). Zircon 91500 was used as the standard (Wiedenbeck et al., 1995) and the standard silicate glass NIST 610 was used to optimize the machine, with a beam diameter of $30 \mu \mathrm{m}$. Raw count rates for ${ }^{29} \mathrm{Si}$, ${ }^{204} \mathrm{~Pb},{ }^{206} \mathrm{~Pb},{ }^{207} \mathrm{~Pb},{ }^{208} \mathrm{~Pb},{ }^{232} \mathrm{Th}$ and ${ }^{238} \mathrm{U}$ were collected and $\mathrm{U}$, Th and $\mathrm{Pb}$ concentrations were calibrated using ${ }^{29} \mathrm{Si}$ as the internal calibrant and NIST 610 as the reference material. ${ }^{207} \mathrm{~Pb} /{ }^{206} \mathrm{~Pb}$ and ${ }^{206} \mathrm{~Pb} /{ }^{238} \mathrm{U}$ ratios were calculated using the GLITTER program (Jackson et al., 2004). Measured ${ }^{207} \mathrm{~Pb} /{ }^{206} \mathrm{~Pb},{ }^{206} \mathrm{~Pb} /{ }^{238} \mathrm{U}$ and ${ }^{208} \mathrm{~Pb} /{ }^{232} \mathrm{Th}$ ratios in zircon 91500 were averaged over the course of the analytical session and used to calculate correction factors. These correction factors were then applied to each sample to correct for both instrumental mass bias and depth-dependent elemental and isotopic fractionation. Common $\mathrm{Pb}$ was corrected by ComPbCorr\#3 151 (Andersen, 2002) for those with common ${ }^{206} \mathrm{~Pb}>1 \%$. Further detailed descriptions of the instrumentation and analytical procedure for the LA-ICP-MS zircon U-Pb technique can be found in Gao et al., (2002) and Liu et al., (2008, 2010). Uncertainties in the ages listed in Appendix 1 are cited as $1 \sigma$, and the weighted mean ages are quoted at the $95 \%$ confidence level. The age calculations and concordia plots were made using Isoplot (ver 3.0) (Ludwig, 2003). LA-ICP-MS U-Pb zircon data are presented in Appendix 1.

Major element oxides were determined by standard X-ray fluorescence (XRF). The detailed analytical methods were described by Li et al., (2006). Trace elements were analyzed by inductively coupled plasma mass spectrometry (ICP-MS), using a Perkin-Elmer Sciex ELAN 6000 instrument at GIGCAS. Analytical procedures are similar to those described by Li et al.,

1319 (2006). Analytical precision for most elements is better than 3\%. Results are listed in Appendix 1320 2.

[Insert Running title of $<72$ characters] 
$1322 \mathrm{Sr}$ and $\mathrm{Nd}$ isotopic analyses were performed on a Micromass Isoprobe multi-collector ICPMS at the GIGCAS, using analytical procedures described by Li et al., (2006). Sr and REE were separated using cation columns, and Nd fractions were further separated by HDEHP-coated Kef columns. Measured ${ }^{87} \mathrm{Sr} /{ }^{86} \mathrm{Sr}$ and ${ }^{143} \mathrm{Nd} /{ }^{144} \mathrm{Nd}$ ratios were normalized to ${ }^{86} \mathrm{Sr} /{ }^{88} \mathrm{Sr}=0.1194$ and ${ }^{146} \mathrm{Nd} /{ }^{144} \mathrm{Nd}=0.7219$, respectively. The reported ${ }^{87} \mathrm{Sr} /{ }^{86} \mathrm{Sr}$ and ${ }^{143} \mathrm{Nd} /{ }^{144} \mathrm{Nd}$ ratios were adjusted to the NBS SRM 987 standard ${ }^{87} \mathrm{Sr} /{ }^{86} \mathrm{Sr}=0.71025$ and the Shin Etsu JNdi-1 standard ${ }^{143} \mathrm{Nd} /{ }^{144} \mathrm{Nd}=0.512115$.

For $\mathrm{Pb}$ isotopic determinations, about $100 \mathrm{mg}$ powder was weighed into the Teflon beaker, spiked and dissolved in concentrated $\mathrm{HF}$ at $180^{\circ} \mathrm{C}$ for $7 \mathrm{~h}$. Lead was separated and purified by conventional cation-exchange technique $(\mathrm{AG} 1 \times 8,20-400$ resin) with diluted $\mathrm{HBr}$ as an eluant. Total procedural blanks were less than $50 \mathrm{pg} \mathrm{Pb}$. Isotopic ratios were measured by a VG-354 mass-spectrometer at the GIGCAS. Repeated analyses of SRM 981 yielded average values of

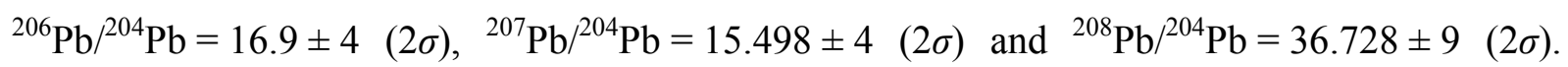
External precisions are estimated to be less than 0.005 and 0.0015 . The detailed analytical procedure is similar to those described by Zhu et al., (2001).

In situ zircon Hf isotopic analyses were conducted using a Neptune MC-ICPMS, equipped with a 193-nm laser, at the Institute of Geology and Geophysics, Chinese Academy of Sciences in Beijing, China. During analyses, spot sizes of 32 and $63 \mathrm{mu}$, with a laser repetition rate of $10 \mathrm{~Hz}$ at $100 \mathrm{~mJ}$, were used and raw count rates for ${ }^{172} \mathrm{Yb},{ }^{173} \mathrm{Yb},{ }^{175} \mathrm{Lu},{ }^{176}(\mathrm{Hf}+\mathrm{Yb}+\mathrm{Lu}),{ }^{177} \mathrm{Hf},{ }^{178} \mathrm{Hf}$, ${ }^{179} \mathrm{Hf},{ }^{180} \mathrm{Hf}$ and ${ }^{182} \mathrm{~W}$ were collected. During laser ablation analyses, the isobaric interference of ${ }^{176} \mathrm{Lu}$ on ${ }^{176} \mathrm{Hf}$ is negligible due to the extremely low ${ }^{176} \mathrm{Lu} /{ }^{177} \mathrm{Hf}$ in zircon (normally $<0.002$ ). However, the interference of ${ }^{176} \mathrm{Yb}$ on ${ }^{176} \mathrm{Hf}$ must be carefully corrected since the contribution of ${ }^{176} \mathrm{Yb}$ to ${ }^{176} \mathrm{Hf}$ could profoundly affect the accuracy of the measured ${ }^{176} \mathrm{Hf} /{ }^{177} \mathrm{Hf}$ ratio. In this project, the mean ${ }^{173} \mathrm{Yb} /{ }^{171} \mathrm{Yb}$ ratio of the individual spots was used to calculate the fractionation coefficient $\left(\beta_{\mathrm{Yb}}\right)$, and then to calculate the contribution of ${ }^{176} \mathrm{Yb}$ to ${ }^{176} \mathrm{Hf}$. During analysis, an isotopic ratio of ${ }^{176} \mathrm{Yb} /{ }^{172} \mathrm{Yb}=0.5887$ was applied. The detailed analytical technique is described in $\mathrm{Wu}$ et al., (2006). During the analytical period, the ${ }^{176} \mathrm{Hf} /{ }^{177} \mathrm{Hf}$ and ${ }^{176} \mathrm{Lu} /{ }^{177} \mathrm{Hf}$ ratios of the standard zircon $(91500)$ were $0.282294 \pm 15\left(2 \sigma_{n}, n=20\right)$ and 0.00031 , similar to the low peaks of 
[First Authors Last Name] Page 57

1352

1353

1354

1355

1356

1357

1358

1359

1360

1361

1362

1363

1364

1365

1366

1367

1368

1369

1370

1371

1372

1373

1374

1375

1376

1377

1378

1379

1380

1381

${ }^{176} \mathrm{Hf}^{177} \mathrm{Hf}$ ratios of $0.282284 \pm 22$ measured by Griffin et al., (2006), also using the laser method.

\section{References}

Andersen, T. 2002. Correction of common lead in U-Pb analyses that do not report ${ }^{204} \mathrm{~Pb}$. Chemical Geology 192, 59-79.

Gao, S., Liu, X.M., Yuan, H.L., Hattendorf, B., Günther, D., Chen, L., and Hu, S.H., 2002. Determination of forty two major and trace elements in USGS and NIST SRM glasses by laser ablationinductively coupled plasma-mass spectrometry. Geostand News1 26, 181-195.

Griffin, W.L., Pearson, N.J., Belousova, E.A., and Saeed, A., 2006. Comment: Hf-isotope heterogeneity in zircon 91500. Chemical Geology 233(3-4), 358-363.

Jackson, S.E., Pearson, N.J., Belousova, E. and Griffin, W.L., (2004) The application of laser ablation-inductively coupled plasma-mass spectrometry (LA-ICP-MS) to in situ U-Pb geochronology. Chemical Geology 211, 47-69.

Li, X.H., Li, Z.X., Wingate, M.T.D., Chung, S.L., Liu, Y., Lin, G.C., and Li, W.X., 2006.

Geochemistry of the 755Ma Mundine Well dyke swarm, northwestern Australia: Part of a Neoproterozoic mantle superplume beneath Rodinia? Precambrian Research 146(1-2), $1-15$.

Liu, Y.S., Gao, S., Gao, C.G., Wang, D.B., Zong, K.Q. and Hu, Z.C., 2010. Timing of melt-peridotite interactions in xenoliths of the Trans-North China Orogen: $\mathrm{U}-\mathrm{Pb}$ dating, Hf isotopes and trace elements in zircon. Journal of Petrology, 51(1-2):537-571.

Liu,Y.S., Hu, Z.C., Gao, S., Günther, D., Xu, J., Gao, C.G. and Chen, H.H., (2008) In situ analysis of major and trace elements of anhydrous minerals by LA-ICP-MS without applying an internal standard. Chemical Geology 257, 34-43.

Ludwig, K.R., 2003. User's manual for Isoplot 3.00: a geochronological toolkit for Microsoft Excel. Berkeley Geochronology Center Special Publication 4, 1-70.

Wiedenbeck, M., Allé, P., Corfu, F., Griffin, W.L., Meier, M., Oberli, F., Von Quadt, A., Roddick, J.C., and Spiegel, W., 1995 Three natural zircon standards for U-Th-Pb, Lu-Hf, trace element and REE analyses. Geostand News1 19, 1-23.

[Insert Running title of $<72$ characters] 
1382

1383

1384

1385

1386

1387

1388
Wu, F.Y., Yang, Y.H., Xie, L.W., Yang, J.H. and Xu, P., 2006. Hf isotopic compositions of the standard zircons and baddeleyites used in $\mathrm{U}-\mathrm{Pb}$ geochronology. Chemical Geology 234(1-2), 105-126.

Zhu, B., Zhang, J., Tu, X., Chang, X., Fan, C., Liu, Y., and Liu, J., 2001. Pb, Sr, and Nd isotopic features in organic matter from China and their implications for petroleum generation and migration. Geochimica et Cosmochimica Acta 65(15), 2555-2570.

[Insert Running title of $<72$ characters] 
[First Authors Last Name] Page 59

1389

1390

\begin{tabular}{|c|c|c|c|c|c|c|c|c|c|c|c|c|c|c|c|}
\hline \multirow{2}{*}{ Analysis } & \multicolumn{2}{|c|}{ Content (ppm) } & \multirow{2}{*}{$\mathrm{Th} / \mathrm{U}$} & \multicolumn{6}{|c|}{ Isotopic ratios } & \multicolumn{6}{|c|}{ Isotopic ages(Ma) } \\
\hline & Th & $\mathrm{U}$ & & ${ }^{207} \mathrm{~Pb} /{ }^{206} \mathrm{~Pb}$ & $1 \sigma$ & ${ }^{207} \mathrm{~Pb} /{ }^{235} \mathrm{U}$ & $1 \sigma$ & ${ }^{206} \mathrm{~Pb} /{ }^{238} \mathrm{U}$ & $1 \sigma$ & ${ }^{207} \mathrm{~Pb} /{ }^{206} \mathrm{~Pb}$ & $1 \sigma$ & ${ }^{207} \mathrm{~Pb} /{ }^{235} \mathrm{U}$ & $1 \sigma$ & ${ }^{206} \mathrm{~Pb} /{ }^{238} \mathrm{U}$ & $1 \sigma$ \\
\hline \multicolumn{16}{|l|}{ Lamasu } \\
\hline $06 \mathrm{XJ17-1}$ & 252 & 558 & 0.45 & 0.05491 & 0.00098 & 0.44026 & 0.00789 & 0.05815 & 0.00066 & 409 & 21 & 370 & 6 & 364 & 4 \\
\hline $06 \mathrm{XJ} 17-2$ & 191 & 676 & 0.28 & 0.05564 & 0.00074 & 0.44871 & 0.00616 & 0.05849 & 0.00064 & 438 & 14 & 376 & 4 & 366 & 4 \\
\hline $06 \mathrm{XJ17-3}$ & 171 & 602 & 0.28 & 0.05543 & 0.00079 & 0.44953 & 0.00657 & 0.05882 & 0.00065 & 430 & 15 & 377 & 5 & 368 & 4 \\
\hline $06 \mathrm{XJ17-4}$ & 399 & 875 & 0.46 & 0.05491 & 0.00072 & 0.44436 & 0.00601 & 0.05869 & 0.00064 & 409 & 14 & 373 & 4 & 368 & 4 \\
\hline $06 \mathrm{XJ} 17-5$ & 207 & 526 & 0.39 & 0.05520 & 0.00088 & 0.49318 & 0.00798 & 0.06480 & 0.00073 & 420 & 18 & 407 & 5 & 405 & 4 \\
\hline 06XJ17-6 & 317 & 298 & 1.07 & 0.05397 & 0.00087 & 0.43654 & 0.00715 & 0.05867 & 0.00066 & 370 & 18 & 368 & 5 & 368 & 4 \\
\hline 06XJ17-7 & 338 & 761 & 0.44 & 0.05505 & 0.00077 & 0.44136 & 0.00635 & 0.05815 & 0.00064 & 414 & 15 & 371 & 4 & 364 & 4 \\
\hline $06 \mathrm{XJ} 17-8$ & 399 & 655 & 0.61 & 0.05395 & 0.00076 & 0.43456 & 0.00626 & 0.05842 & 0.00065 & 369 & 15 & 366 & 4 & 366 & 4 \\
\hline 06XJ17-9 & 123 & 256 & 0.48 & 0.05580 & 0.00100 & 0.45052 & 0.00813 & 0.05856 & 0.00067 & 444 & 21 & 378 & 6 & 367 & 4 \\
\hline $06 \mathrm{XJ17}-10$ & 386 & 930 & 0.41 & 0.05483 & 0.00077 & 0.44615 & 0.00648 & 0.05902 & 0.00065 & 405 & 15 & 375 & 5 & 370 & 4 \\
\hline $06 \mathrm{XJ17-11}$ & 149 & 285 & 0.52 & 0.05620 & 0.00104 & 0.45087 & 0.00838 & 0.05818 & 0.00067 & 460 & 22 & 378 & 6 & 365 & 4 \\
\hline $06 \mathrm{XJ} 17-12$ & 153 & 620 & 0.25 & 0.05343 & 0.00124 & 0.43225 & 0.00886 & 0.05867 & 0.00065 & 347 & 54 & 365 & 6 & 368 & 4 \\
\hline 06XJ17-13 & 133 & 336 & 0.40 & 0.05502 & 0.00087 & 0.44098 & 0.00707 & 0.05813 & 0.00065 & 413 & 18 & 371 & 5 & 364 & 4 \\
\hline 06XJ17-14 & 220 & 573 & 0.38 & 0.05589 & 0.00095 & 0.49558 & 0.00853 & 0.06431 & 0.00073 & 448 & 19 & 409 & 6 & 402 & 4 \\
\hline 06XJ17-15 & 245 & 455 & 0.54 & 0.05474 & 0.00083 & 0.44193 & 0.00685 & 0.05855 & 0.00066 & 402 & 17 & 372 & 5 & 367 & 4 \\
\hline 06XJ17-16 & 295 & 630 & 0.47 & 0.05477 & 0.00083 & 0.44530 & 0.00691 & 0.05897 & 0.00066 & 403 & 17 & 374 & 5 & 369 & 4 \\
\hline 06XJ17-17 & 114 & 329 & 0.35 & 0.05551 & 0.00099 & 0.49000 & 0.00881 & 0.06403 & 0.00073 & 433 & 21 & 405 & 6 & 400 & 4 \\
\hline 06XJ17-18 & 143 & 366 & 0.39 & 0.05442 & 0.00088 & 0.43387 & 0.00714 & 0.05782 & 0.00065 & 388 & 18 & 366 & 5 & 362 & 4 \\
\hline 06XJ17-19 & 30 & 262 & 0.12 & 0.06911 & 0.00116 & 1.41784 & 0.02419 & 0.14880 & 0.00171 & 902 & 18 & 896 & 10 & 894 & 10 \\
\hline 06XJ17-20 & 282 & 715 & 0.39 & 0.06625 & 0.00097 & 1.10806 & 0.01657 & 0.12131 & 0.00136 & 814 & 15 & 757 & 8 & 738 & 8 \\
\hline 06XJ17-21 & 311 & 732 & 0.42 & 0.06893 & 0.00100 & 1.33419 & 0.01980 & 0.14039 & 0.00158 & 897 & 14 & 861 & 9 & 847 & 9 \\
\hline $06 \mathrm{XJ17}-22$ & 255 & 889 & 0.29 & 0.05407 & 0.00086 & 0.43435 & 0.00701 & 0.05826 & 0.00066 & 374 & 18 & 366 & 5 & 365 & 4 \\
\hline $06 \mathrm{XJ} 17-23$ & 48 & 312 & 0.15 & 0.05670 & 0.00099 & 0.45608 & 0.00803 & 0.05834 & 0.00067 & 480 & 20 & 382 & 6 & 366 & 4 \\
\hline 06XJ17-24 & 462 & 950 & 0.49 & 0.06905 & 0.00103 & 1.43796 & 0.02192 & 0.15104 & 0.00170 & 900 & 15 & 905 & 9 & 907 & 10 \\
\hline \multicolumn{16}{|l|}{ Dabate dacite } \\
\hline 06XJ04 01 & 329 & 409 & 0.80 & 0.05537 & 0.00203 & 0.51241 & 0.01784 & 0.06714 & 0.00097 & 427 & 52 & 420 & 12 & 419 & 6 \\
\hline 06XJ04 02 & 127 & 165 & 0.77 & 0.05693 & 0.00373 & 0.39931 & 0.02499 & 0.05087 & 0.00110 & 489 & 100 & 341 & 18 & 320 & 7 \\
\hline 06XJ04 03 & 147 & 141 & 1.04 & 0.05157 & 0.00367 & 0.35842 & 0.02445 & 0.05041 & 0.00114 & 266 & 115 & 311 & 18 & 317 & 7 \\
\hline 06XJ04 04 & 357 & 366 & 0.97 & 0.06736 & 0.00288 & 0.62669 & 0.02523 & 0.06747 & 0.00117 & 849 & 55 & 494 & 16 & 421 & 7 \\
\hline 06XJ04 05 & 176 & 339 & 0.52 & 0.07172 & 0.00152 & 1.60833 & 0.03168 & 0.16263 & 0.00182 & 978 & 22 & 973 & 12 & 971 & 10 \\
\hline
\end{tabular}

Appendix 2 LA-ICP-MS zircon U-Pb isotopic analyses for the magmatic rocks from the Lamasu-Dabate area
1392

[Insert Running title of $<72$ characters] 
[First Authors Last Name] Page 60

1393

Appendix 2 Continued

\begin{tabular}{|c|c|c|c|c|c|c|c|c|c|c|c|c|c|c|c|}
\hline \multirow{2}{*}{ Analysis } & \multicolumn{2}{|c|}{ Content (ppm) } & \multirow{2}{*}{$\mathrm{Th} / \mathrm{U}$} & \multicolumn{6}{|c|}{ Isotopic ratios } & \multicolumn{6}{|c|}{ Isotopic ages(Ma) } \\
\hline & Th & $\mathrm{U}$ & & ${ }^{207} \mathrm{~Pb} /{ }^{206} \mathrm{~Pb}$ & $1 \sigma$ & ${ }^{207} \mathrm{~Pb} /{ }^{235} \mathrm{U}$ & $1 \sigma$ & ${ }^{206} \mathrm{~Pb} /{ }^{238} \mathrm{U}$ & $1 \sigma$ & ${ }^{207} \mathrm{~Pb} /{ }^{206} \mathrm{~Pb}$ & $1 \sigma$ & ${ }^{207} \mathrm{~Pb} /{ }^{235} \mathrm{U}$ & $1 \sigma$ & ${ }^{206} \mathrm{~Pb} /{ }^{238} \mathrm{U}$ & $1 \sigma$ \\
\hline 06XJ04 06 & 256 & 680 & 0.38 & 0.06944 & 0.0019 & 1.22167 & 0.03138 & 0.12759 & 0.00165 & 912 & 32 & 811 & 14 & 774 & 9 \\
\hline 06XJ04 07 & 95 & 127 & 0.75 & 0.05378 & 0.00437 & 0.37927 & 0.02959 & 0.05115 & 0.00131 & 362 & 130 & 327 & 22 & 322 & 8 \\
\hline 06XJ04 08 & 78 & 104 & 0.75 & 0.05795 & 0.00473 & 0.40011 & 0.03122 & 0.05007 & 0.00135 & 528 & 124 & 342 & 23 & 315 & 8 \\
\hline 06XJ04 09 & 149 & 153 & 0.97 & 0.05442 & 0.00767 & 0.36992 & 0.05005 & 0.04929 & 0.00215 & 388 & 224 & 320 & 37 & 310 & 13 \\
\hline 06XJ04 10 & 214 & 327 & 0.66 & 0.0472 & 0.0031 & 0.32256 & 0.02036 & 0.04956 & 0.00103 & 59 & 99 & 284 & 16 & 312 & 6 \\
\hline 06XJ04 11 & 68 & 150 & 0.45 & 0.05476 & 0.00486 & 0.39093 & 0.0332 & 0.05176 & 0.00150 & 402 & 139 & 335 & 24 & 325 & 9 \\
\hline 06XJ04 12 & 1645 & 1246 & 1.32 & 0.07089 & 0.00231 & 0.48748 & 0.01483 & 0.04985 & 0.00070 & 954 & 39 & 403 & 10 & 314 & 4 \\
\hline \multicolumn{16}{|l|}{ Dabate granite } \\
\hline 06XJ013-1 & 61 & 105 & 0.58 & 0.05397 & 0.00238 & 0.37540 & 0.01586 & 0.05045 & 0.00064 & 370 & 102 & 324 & 12 & 317 & 4 \\
\hline 06XJ013-2 & 193 & 358 & 0.54 & 0.07118 & 0.00116 & 0.45377 & 0.00749 & 0.04623 & 0.00052 & 963 & 17 & 380 & 5 & 291 & 3 \\
\hline 06XJ013-3 & 146 & 290 & 0.50 & 0.05402 & 0.00166 & 0.34298 & 0.00980 & 0.04604 & 0.00053 & 372 & 71 & 299 & 7 & 290 & 3 \\
\hline 06XJ013-4 & 302 & 509 & 0.59 & 0.05359 & 0.00072 & 0.34155 & 0.00473 & 0.04622 & 0.00051 & 354 & 14 & 298 & 4 & 291 & 3 \\
\hline 06XJ013-5 & 29 & 61 & 0.48 & 0.05311 & 0.00138 & 0.33785 & 0.00873 & 0.04614 & 0.00056 & 333 & 37 & 296 & 7 & 291 & 3 \\
\hline 06XJ013-6 & 79 & 155 & 0.51 & 0.05310 & 0.00196 & 0.37170 & 0.01301 & 0.05077 & 0.00061 & 333 & 86 & 321 & 10 & 319 & 4 \\
\hline 06XJ013-7 & 50 & 175 & 0.28 & 0.05339 & 0.00099 & 0.33923 & 0.00633 & 0.04609 & 0.00052 & 345 & 23 & 297 & 5 & 290 & 3 \\
\hline 06XJ013-8 & 356 & 677 & 0.53 & 0.05327 & 0.00077 & 0.33625 & 0.00501 & 0.04578 & 0.00050 & 340 & 16 & 294 & 4 & 289 & 3 \\
\hline 06XJ013-9 & 324 & 545 & 0.59 & 0.05314 & 0.00070 & 0.34021 & 0.00466 & 0.04643 & 0.00051 & 335 & 14 & 297 & 4 & 293 & 3 \\
\hline 06XJ013-10 & 455 & 615 & 0.74 & 0.06762 & 0.00272 & 0.41114 & 0.01572 & 0.04410 & 0.00055 & 857 & 86 & 350 & 11 & 278 & 3 \\
\hline 06XJ013-11 & 106 & 190 & 0.56 & 0.05341 & 0.00107 & 0.37410 & 0.00751 & 0.05079 & 0.00058 & 346 & 25 & 323 & 6 & 319 & 4 \\
\hline 06XJ013-12 & 137 & 221 & 0.62 & 0.05675 & 0.00093 & 0.36120 & 0.00599 & 0.04616 & 0.00051 & 482 & 19 & 313 & 4 & 291 & 3 \\
\hline 06XJ013-13 & 256 & 317 & 0.81 & 0.05244 & 0.00077 & 0.33593 & 0.00504 & 0.04646 & 0.00051 & 305 & 16 & 294 & 4 & 293 & 3 \\
\hline 06XJ013-14 & 850 & 1616 & 0.53 & 0.06358 & 0.00600 & 0.33191 & 0.03097 & 0.03786 & 0.00054 & 728 & 208 & 291 & 24 & 240 & 3 \\
\hline 06XJ013-15 & 65 & 169 & 0.38 & 0.05196 & 0.00094 & 0.33400 & 0.00612 & 0.04662 & 0.00053 & 284 & 22 & 293 & 5 & 294 & 3 \\
\hline 06XJ013-16 & 89 & 167 & 0.53 & 0.05841 & 0.00238 & 0.35907 & 0.01394 & 0.04458 & 0.00056 & 545 & 91 & 312 & 10 & 281 & 3 \\
\hline 06XJ013-17 & 645 & 1253 & 0.51 & 0.06261 & 0.00092 & 0.36572 & 0.00551 & 0.04236 & 0.00047 & 695 & 15 & 316 & 4 & 267 & 3 \\
\hline 06XJ013-18 & 139 & 499 & 0.28 & 0.05614 & 0.00079 & 0.39290 & 0.00569 & 0.05075 & 0.00056 & 458 & 15 & 336 & 4 & 319 & 3 \\
\hline 06XJ013-19 & 669 & 663 & 1.01 & 0.06496 & 0.00090 & 0.40648 & 0.00580 & 0.04538 & 0.00050 & 773 & 14 & 346 & 4 & 286 & 3 \\
\hline 06XJ013-20 & 290 & 460 & 0.63 & 0.05735 & 0.00200 & 0.35351 & 0.01162 & 0.04470 & 0.00052 & 505 & 79 & 307 & 9 & 282 & 3 \\
\hline 06XJ013-22 & 199 & 414 & 0.48 & 0.06178 & 0.00091 & 0.39809 & 0.00600 & 0.04673 & 0.00052 & 667 & 15 & 340 & 4 & 294 & 3 \\
\hline 06XJ013-23 & 349 & 644 & 0.54 & 0.05353 & 0.00078 & 0.34120 & 0.00509 & 0.04622 & 0.00051 & 351 & 16 & 298 & 4 & 291 & 3 \\
\hline 06XJ013-24 & 178 & 365 & 0.49 & 0.05154 & 0.00161 & 0.32488 & 0.00942 & 0.04572 & 0.00053 & 265 & 73 & 286 & 7 & 288 & 3 \\
\hline 06XJ013-25 & 139 & 383 & 0.36 & 0.05433 & 0.00080 & 0.34127 & 0.00515 & 0.04556 & 0.00050 & 385 & 16 & 298 & 4 & 287 & 3 \\
\hline
\end{tabular}

1394

1395

[Insert Running title of $<72$ characters] 
[First Authors Last Name] Page 61

1396 Appendix 3 Major and trace element data for the magmatic rocks from the Lamasu-Dabate area

\begin{tabular}{|c|c|c|c|c|c|c|c|c|c|c|}
\hline $\begin{array}{l}\text { Sample } \\
\text { Location }\end{array}$ & $\begin{array}{c}\text { 06XJ-16 } \\
\text { Lamasu }\end{array}$ & $\begin{array}{c}\text { 06XJ-017 } \\
\text { Lamasu }\end{array}$ & $\begin{array}{c}\text { 06XJ-018 } \\
\text { Lamasu }\end{array}$ & $\begin{array}{c}\text { 06XJ-19-1 } \\
\text { Lamasu }\end{array}$ & $\begin{array}{c}\text { 06XJ-19-2 } \\
\text { Lamasu }\end{array}$ & $\begin{array}{c}\text { 06XJ-20 } \\
\text { Lamasu }\end{array}$ & $\begin{array}{c}\text { 06XJ-21-1 } \\
\text { Lamasu }\end{array}$ & $\begin{array}{c}06 \mathrm{XJ}-22 \\
\text { Lamasu }\end{array}$ & $\begin{array}{c}\text { 06XJ-23-1 } \\
\text { Lamasu }\end{array}$ & $\begin{array}{c}\text { 06XJ-23-2 } \\
\text { Lamasu }\end{array}$ \\
\hline $\mathrm{SiO} 2$ & 67.86 & 66.85 & 50.66 & 58.30 & 55.89 & 69.46 & 68.33 & 59.70 & 68.23 & 67.25 \\
\hline $\mathrm{TiO} 2$ & 0.30 & 0.31 & 1.75 & 1.21 & 1.40 & 0.25 & 0.30 & 0.38 & 0.34 & 0.34 \\
\hline $\mathrm{A} 12 \mathrm{O} 3$ & 16.67 & 16.59 & 16.79 & 16.25 & 16.88 & 16.04 & 17.06 & 19.75 & 16.47 & 16.46 \\
\hline $\mathrm{FeO}$ & 1.22 & 2.45 & 8.52 & 5.91 & 6.50 & 0.84 & 1.90 & 2.56 & 2.80 & 3.05 \\
\hline $\mathrm{MnO}$ & 0.01 & 0.02 & 0.14 & 0.06 & 0.07 & 0.02 & 0.01 & 0.02 & 0.05 & 0.05 \\
\hline $\mathrm{MgO}$ & 0.88 & 1.28 & 5.81 & 3.38 & 3.73 & 0.75 & 1.37 & 1.69 & 1.16 & 1.23 \\
\hline $\mathrm{CaO}$ & 0.47 & 2.57 & 7.68 & 2.72 & 3.02 & 2.00 & 0.84 & 1.77 & 2.63 & 2.84 \\
\hline $\mathrm{Na} 2 \mathrm{O}$ & 2.49 & 3.50 & 3.15 & 3.32 & 2.61 & 4.79 & 4.24 & 6.52 & 4.06 & 4.33 \\
\hline $\mathrm{K} 2 \mathrm{O}$ & 7.53 & 4.05 & 1.37 & 3.35 & 3.61 & 4.54 & 3.56 & 3.62 & 2.14 & 1.78 \\
\hline $\mathrm{P} 2 \mathrm{O} 5$ & 0.06 & 0.03 & 0.13 & 0.27 & 0.31 & 0.05 & 0.05 & 0.10 & 0.04 & 0.04 \\
\hline LOI & 1.96 & 1.56 & 2.72 & 4.43 & 5.45 & 1.19 & 2.16 & 2.94 & 1.85 & 1.74 \\
\hline Total & 99.60 & 99.48 & 99.66 & 99.84 & 100.19 & 100.03 & 100.04 & 99.34 & 100.09 & 99.44 \\
\hline $\mathrm{Mg} \#$ & 56.21 & 48.23 & 54.83 & 50.42 & 50.56 & 61.20 & 56.33 & 54.02 & 42.43 & 41.85 \\
\hline $\mathrm{Sc}$ & 4.13 & 0.721 & 20.8 & 10.5 & 13.3 & 2.74 & 2.61 & 3.69 & 2.59 & 2.81 \\
\hline $\mathrm{V}$ & 19.8 & 25.6 & 144 & 99.1 & 130 & 25.3 & 26.0 & 42.9 & 38.0 & 31.0 \\
\hline $\mathrm{Cr}$ & 20.3 & 11.9 & 188 & 23.3 & 32.2 & 11.4 & 11.0 & 6.74 & 7.65 & 29.0 \\
\hline Co & 1.36 & 4.41 & 29.4 & 13.9 & 16.6 & 0.680 & 3.22 & 3.60 & 5.50 & 4.92 \\
\hline $\mathrm{Ni}$ & 5.44 & 9.22 & 38.7 & 20.2 & 21.6 & 6.91 & 9.69 & 7.31 & 7.06 & 8.43 \\
\hline $\mathrm{Ga}$ & 15.2 & 13.7 & 18.5 & 18.8 & 19.2 & 13.6 & 17.5 & 16.7 & 16.6 & 16.2 \\
\hline Cs & 13.9 & 4.56 & 2.30 & 4.26 & 5.76 & 3.50 & 6.33 & 7.82 & 2.28 & 4.15 \\
\hline $\mathrm{Rb}$ & 220 & 92.3 & 33.3 & 111 & 136 & 103 & 109 & 128 & 67.3 & 56.3 \\
\hline $\mathrm{Ba}$ & 509 & 235 & 225 & 328 & 297 & 433 & 337 & 347 & 353 & 257 \\
\hline Th & 8.09 & 3.13 & 3.11 & 10.4 & 9.63 & 7.62 & 6.88 & 6.32 & 7.09 & 6.88 \\
\hline $\mathrm{U}$ & 1.09 & 1.10 & 0.721 & 2.11 & 1.78 & 1.79 & 0.954 & 1.22 & 1.00 & 1.28 \\
\hline $\mathrm{Pb}$ & 5.96 & 2.91 & 4.80 & 11.0 & 6.74 & 3.80 & 8.56 & 7.01 & 5.80 & 6.04 \\
\hline $\mathrm{Nb}$ & 6.26 & 4.76 & 9.20 & 12.4 & 13.3 & 8.11 & 6.43 & 5.41 & 6.20 & 6.30 \\
\hline $\mathrm{Ta}$ & 0.606 & 0.456 & 0.583 & 0.813 & 0.866 & 0.784 & 0.554 & 0.488 & 0.591 & 0.573 \\
\hline $\mathrm{Sr}$ & 445 & 308 & 420 & 258 & 132 & 383 & 359 & 401 & 436 & 372 \\
\hline $\mathrm{Y}$ & 13.7 & 10.6 & 21.5 & 24.4 & 23.2 & 16.8 & 12.8 & 13.9 & 15.3 & 14.5 \\
\hline $\mathrm{Zr}$ & 123 & 67.4 & 245 & 228 & 243 & 109 & 93.0 & 130 & 108 & 102 \\
\hline $\mathrm{Hf}$ & 3.23 & 1.98 & 5.22 & 5.64 & 5.77 & 2.99 & 2.59 & 3.56 & 3.16 & 3.09 \\
\hline $\mathrm{La}$ & 17.8 & 9.95 & 12.9 & 33.8 & 33.9 & 10.2 & 14.7 & 18.1 & 19.0 & 17.8 \\
\hline $\mathrm{Ce}$ & 37.7 & 22.2 & 29.6 & 74.0 & 72.1 & 26.8 & 31.0 & 38.1 & 38.1 & 36.8 \\
\hline $\operatorname{Pr}$ & 4.58 & 2.83 & 3.85 & 8.95 & 8.95 & 3.72 & 3.92 & 4.85 & 4.61 & 4.43 \\
\hline $\mathrm{Nd}$ & 16.4 & 10.6 & 15.7 & 33.2 & 33.5 & 14.7 & 14.6 & 17.6 & 17.1 & 16.3 \\
\hline $\mathrm{Sm}$ & 3.06 & 2.08 & 3.58 & 6.01 & 6.05 & 3.01 & 2.75 & 3.07 & 3.12 & 2.94 \\
\hline $\mathrm{Eu}$ & 0.517 & 0.435 & 1.44 & 0.933 & 0.959 & 0.502 & 0.435 & 0.611 & 0.656 & 0.689 \\
\hline $\mathrm{Gd}$ & 2.36 & 1.94 & 3.56 & 5.17 & 5.03 & 2.62 & 2.25 & 2.59 & 2.65 & 2.66 \\
\hline $\mathrm{Tb}$ & 0.403 & 0.326 & 0.614 & 0.803 & 0.803 & 0.446 & 0.366 & 0.401 & 0.470 & 0.415 \\
\hline Dy & 2.27 & 1.91 & 3.79 & 4.57 & 4.24 & 2.63 & 2.06 & 2.29 & 2.55 & 2.55 \\
\hline Ho & 0.490 & 0.388 & 0.805 & 0.870 & 0.840 & 0.550 & 0.431 & 0.499 & 0.521 & 0.506 \\
\hline $\mathrm{Er}$ & 1.39 & 1.12 & 2.27 & 2.42 & 2.24 & 1.57 & 1.22 & 1.40 & 1.47 & 1.45 \\
\hline $\mathrm{Tm}$ & 0.205 & 0.175 & 0.351 & 0.346 & 0.323 & 0.234 & 0.191 & 0.227 & 0.227 & 0.236 \\
\hline $\mathrm{Yb}$ & 1.42 & 1.21 & 2.30 & 2.16 & 2.07 & 1.60 & 1.26 & 1.48 & 1.53 & 1.56 \\
\hline $\mathrm{Lu}$ & 0.225 & 0.184 & 0.384 & 0.329 & 0.318 & 0.255 & 0.196 & 0.239 & 0.237 & 0.248 \\
\hline
\end{tabular}

[Insert Running title of $<72$ characters] 
[First Authors Last Name] Page 62

Appendix 3 Continued

\begin{tabular}{|c|c|c|c|c|c|c|c|c|c|}
\hline & 06XJ-04 & 06XJ-05 & 06XJ-06 & 06XJ-08 & 06XJ-010 & 06XJ-12 & 06XJ-13 & 06XJ-14 & $06 \mathrm{XJ}-15$ \\
\hline Location & Dabate & Dabate & Dabate & Dabate & Dabate & Dabate & Dabate & Dabate & Dabate \\
\hline $\mathrm{SiO} 2$ & 63.95 & 62.18 & 62.50 & 75.56 & 75.67 & 76.92 & 76.36 & 75.38 & 77.61 \\
\hline $\mathrm{TiO} 2$ & 0.94 & 0.71 & 0.66 & 0.08 & 0.12 & 0.09 & 0.11 & 0.10 & 0.10 \\
\hline $\mathrm{A} 12 \mathrm{O} 3$ & 14.60 & 15.41 & 16.02 & 12.80 & 12.04 & 12.91 & 12.72 & 12.64 & 12.97 \\
\hline $\mathrm{FeO}$ & 5.55 & 6.38 & 4.91 & 1.04 & 1.02 & 0.85 & 1.16 & 1.05 & 0.88 \\
\hline $\mathrm{MnO}$ & 0.05 & 0.02 & 0.10 & 0.00 & 0.00 & 0.00 & 0.00 & 0.00 & 0.00 \\
\hline $\mathrm{MgO}$ & 1.72 & 2.82 & 3.25 & 0.05 & 0.05 & 0.01 & 0.01 & 0.06 & 0.01 \\
\hline $\mathrm{CaO}$ & 3.02 & 0.33 & 4.16 & 0.03 & 0.03 & 0.28 & 0.34 & 0.42 & 0.31 \\
\hline $\mathrm{Na} 2 \mathrm{O}$ & 3.11 & 3.99 & 3.17 & 2.47 & 1.39 & 3.00 & 3.56 & 4.06 & 3.27 \\
\hline $\mathrm{K} 2 \mathrm{O}$ & 3.14 & 5.53 & 2.24 & 7.63 & 8.08 & 5.27 & 5.14 & 4.92 & 5.21 \\
\hline $\mathrm{P} 2 \mathrm{O} 5$ & 0.11 & 0.05 & 0.09 & 0.01 & 0.01 & 0.01 & 0.01 & 0.01 & 0.00 \\
\hline LOI & 2.69 & 1.50 & 2.25 & 0.62 & 0.88 & 0.79 & 0.87 & 0.79 & -0.31 \\
\hline Total & 99.49 & 99.64 & 99.92 & 100.40 & 99.41 & 100.21 & 100.40 & 99.54 & 100.14 \\
\hline $\mathrm{Mg \#}$ & 35.56 & 44.07 & 54.11 & 7.28 & 8.67 & 2.05 & 1.52 & 8.75 & 1.99 \\
\hline $\mathrm{Sc}$ & 15.3 & 14.8 & 10.7 & 0.121 & 0.0450 & 2.19 & 0.0420 & 0.849 & 0.137 \\
\hline $\mathrm{V}$ & 88.2 & 102 & 98.0 & 9.09 & 15.6 & 3.95 & 7.98 & 19.6 & 7.36 \\
\hline $\mathrm{Cr}$ & 32.2 & 53.8 & 66.7 & 4.20 & 8.43 & 15.6 & 2.51 & 7.25 & 12.2 \\
\hline $\mathrm{Co}$ & 13.5 & 0.859 & 17.2 & 0.424 & 0.768 & 0.518 & 0.625 & 0.452 & 0.652 \\
\hline $\mathrm{Ni}$ & 14.4 & 39.5 & 51.7 & 1.41 & 2.63 & 3.06 & 2.09 & 1.83 & 7.61 \\
\hline $\mathrm{Ga}$ & 18.3 & 17.0 & 17.6 & 20.8 & 19.8 & 21.8 & 22.8 & 25.2 & 23.2 \\
\hline Cs & 3.95 & 77.0 & 4.67 & 20.0 & 18.4 & 15.3 & 14.5 & 17.2 & 18.6 \\
\hline $\mathrm{Rb}$ & 87.6 & 459 & 61.7 & 316 & 357 & 265 & 264 & 286 & 287 \\
\hline $\mathrm{Ba}$ & 641 & 476 & 314 & 110 & 209 & 144 & 150 & 107 & 109 \\
\hline $\mathrm{Th}$ & 7.57 & 5.07 & 4.58 & 15.4 & 13.0 & 20.2 & 15.3 & 18.7 & 12.5 \\
\hline $\mathrm{U}$ & 1.82 & 1.26 & 1.09 & 3.72 & 2.92 & 3.38 & 2.38 & 2.50 & 7.44 \\
\hline $\mathrm{Pb}$ & 10.7 & 4.97 & 8.23 & 9.52 & 6.15 & 10.1 & 9.80 & 14.4 & 12.5 \\
\hline $\mathrm{Nb}$ & 8.73 & 7.21 & 6.89 & 25.2 & 20.6 & 24.8 & 25.6 & 27.5 & 24.2 \\
\hline $\mathrm{Ta}$ & 0.496 & 0.432 & 0.425 & 2.29 & 1.82 & 2.18 & 2.04 & 2.28 & 2.10 \\
\hline $\mathrm{Sr}$ & 213 & 208 & 394 & 35.1 & 29.3 & 22.8 & 27.1 & 18.6 & 17.9 \\
\hline $\mathrm{Y}$ & 38.2 & 19.9 & 19.3 & 40.8 & 29.6 & 57.3 & 52.7 & 58.7 & 51.5 \\
\hline $\mathrm{Zr}$ & 277 & 138 & 134 & 91.6 & 101 & 140 & 128 & 142 & 121 \\
\hline $\mathrm{Hf}$ & 5.64 & 2.96 & 2.98 & 4.08 & 4.05 & 5.81 & 5.29 & 5.83 & 5.29 \\
\hline $\mathrm{La}$ & 23.8 & 7.89 & 13.2 & 8.17 & 6.63 & 19.1 & 15.9 & 18.8 & 13.3 \\
\hline $\mathrm{Ce}$ & 52.1 & 16.9 & 28.1 & 22.5 & 17.3 & 46.7 & 37.4 & 43.9 & 31.7 \\
\hline $\operatorname{Pr}$ & 6.64 & 2.22 & 3.65 & 3.23 & 2.40 & 6.20 & 4.90 & 6.04 & 4.22 \\
\hline $\mathrm{Nd}$ & 26.8 & 8.43 & 14.4 & 13.6 & 10.5 & 23.6 & 18.5 & 23.1 & 15.9 \\
\hline $\mathrm{Sm}$ & 5.80 & 1.97 & 3.16 & 4.86 & 3.35 & 6.65 & 5.12 & 6.42 & 4.64 \\
\hline $\mathrm{Eu}$ & 1.03 & 0.543 & 0.768 & 0.145 & 0.154 & 0.268 & 0.211 & 0.225 & 0.199 \\
\hline $\mathrm{Gd}$ & 5.37 & 1.98 & 2.98 & 5.26 & 3.48 & 7.84 & 6.08 & 7.37 & 5.97 \\
\hline $\mathrm{Tb}$ & 0.972 & 0.414 & 0.517 & 1.11 & 0.710 & 1.61 & 1.38 & 1.59 & 1.39 \\
\hline Dy & 5.81 & 2.83 & 2.99 & 6.76 & 4.44 & 10.1 & 8.70 & 9.62 & 8.74 \\
\hline Ho & 1.20 & 0.624 & 0.635 & 1.39 & 0.923 & 2.11 & 1.78 & 2.07 & 1.86 \\
\hline $\mathrm{Er}$ & 3.42 & 1.86 & 1.73 & 3.74 & 2.64 & 5.94 & 5.06 & 5.76 & 5.28 \\
\hline $\mathrm{Tm}$ & 0.508 & 0.295 & 0.262 & 0.575 & 0.428 & 0.919 & 0.729 & 0.873 & 0.787 \\
\hline $\mathrm{Yb}$ & 3.07 & 1.86 & 1.65 & 3.67 & 2.73 & 5.80 & 4.78 & 5.47 & 4.87 \\
\hline $\mathrm{Lu}$ & 0.466 & 0.277 & 0.232 & 0.517 & 0.409 & 0.887 & 0.687 & 0.788 & 0.720 \\
\hline
\end{tabular}

[Insert Running title of $<72$ characters] 
[First Authors Last Name] Page 63

1399 Appendix $4 \mathrm{Sr}, \mathrm{Nd}$ and $\mathrm{Pb}$ isotopic compositions for the magmatic rocks from the Lamasu-Dabate area

\begin{tabular}{|c|c|c|c|c|c|c|c|c|c|c|c|c|}
\hline Sample & $\mathrm{T}(\mathrm{Ma})$ & $\mathrm{Rb}(\mathrm{ppm})$ & $\operatorname{Sr}(\mathrm{ppm})$ & ${ }^{87} \mathrm{Rb}^{86} \mathrm{Sr}$ & ${ }^{87} \mathrm{Sr} /{ }^{86} \mathrm{Sr}$ & $2 \sigma$ & ${ }^{87} \mathrm{Sr}^{86} \mathrm{Sr}_{\mathrm{i}}$ & $\mathrm{Sm}$ & $\mathrm{Nd}$ & ${ }^{147} \mathrm{Sm} /{ }^{144} \mathrm{Nd}$ & ${ }^{143} \mathrm{Nd} /{ }^{144} \mathrm{Nd}$ & $2 \sigma$ \\
\hline 06XJ017 & 366 & 92.34 & 308.3 & 0.844659 & 0.711848 & 5 & 0.707446 & 2.082 & 10.6 & 0.119544 & 0.5122663 & 6 \\
\hline 06XJ018 & 366 & 33.28 & 420 & 0.223460 & 0.707117 & 5 & 0.705952 & 3.575 & 15.66 & 0.138943 & 0.5126735 & 5 \\
\hline 06XJ19-2 & 366 & 135.7 & 131.9 & 2.901350 & 0.711690 & 8 & 0.696572 & 6.054 & 33.48 & 0.110055 & 0.5125016 & 6 \\
\hline 06XJ20 & 366 & 102.5 & 382.7 & 0.755319 & 0.711619 & 5 & 0.707683 & 3.013 & 14.69 & 0.124833 & 0.5121772 & 5 \\
\hline 06XJ22 & 366 & 127.5 & 401.2 & 0.896219 & 0.711962 & 5 & 0.707292 & 3.071 & 17.64 & 0.105958 & 0.5123794 & 6 \\
\hline $06 \mathrm{XJ} 23-2$ & 366 & 56.33 & 371.5 & 0.427608 & 0.709432 & 5 & 0.707204 & 2.938 & 16.29 & 0.109770 & 0.5122389 & 6 \\
\hline 06XJ04 & 316 & 87.56 & 213.20 & 1.158200 & 0.710678 & 14 & 0.705469 & 5.804 & 26.8 & 0.130495 & 0.5126721 & 9 \\
\hline 06XJ06 & 316 & 61.73 & 393.70 & 0.442177 & 0.706593 & 9 & 0.704604 & 3.164 & 14.44 & 0.137374 & 0.5125097 & 7 \\
\hline 06XJ010 & 290 & 356.5 & 29.25 & & & & & 3.352 & 10.46 & 0.195041 & 0.512635 & 6 \\
\hline 06XJ13 & 290 & 264.2 & 27.14 & & & & & 5.117 & 18.47 & 0.168617 & 0.5125342 & 6 \\
\hline 06XJ15 & 290 & 286.9 & 17.87 & & & & & 4.638 & 15.86 & 0.177984 & 0.5125141 & 5 \\
\hline Sample & $\varepsilon \mathrm{Nd}(\mathrm{t})$ & $\mathrm{T}_{\mathrm{Nd} 2 \mathrm{DM}}$ & $\mathrm{f}_{\mathrm{Sm} / \mathrm{Nd}}$ & $\mathrm{Th}(\mathrm{ppm})$ & $\mathrm{U}(\mathrm{ppm})$ & $\mathrm{Pb}(\mathrm{ppm})$ & ${ }^{206} \mathrm{~Pb} /{ }^{204} \mathrm{~Pb}$ & ${ }^{207} \mathrm{~Pb} /{ }^{204} \mathrm{~Pb}$ & ${ }^{208} \mathrm{~Pb} /{ }^{204} \mathrm{~Pb}$ & ${ }^{206} \mathrm{~Pb} /{ }^{204} \mathrm{Pbt}$ & ${ }^{207} \mathrm{~Pb} /{ }^{204} \mathrm{Pbt}$ & ${ }^{208} \mathrm{~Pb} /{ }^{204} \mathrm{Pbt}$ \\
\hline 06XJ017 & -3.65 & 1423 & -0.39 & 3.129 & 1.095 & 2.907 & 19.806 & 15.628 & 39.449 & 18.139 & 15.5381 & 37.9483 \\
\hline 06XJ018 & 3.40 & 847 & -0.29 & 3.109 & 0.721 & 4.799 & 18.694 & 15.651 & 38.634 & 18.0458 & 15.616 & 37.7534 \\
\hline 06XJ19-2 & 1.39 & 1011 & -0.44 & 9.632 & 1.782 & 6.741 & 19.068 & 15.618 & 39.491 & 17.909 & 15.5555 & 37.5173 \\
\hline 06XJ20 & -5.63 & 1585 & -0.37 & 7.615 & 1.789 & 3.796 & 20.241 & 15.659 & 39.389 & 18.1442 & 15.5459 & 36.5771 \\
\hline 06XJ22 & -0.80 & 1191 & -0.46 & 6.316 & 1.216 & 7.013 & 19.206 & 15.622 & 38.981 & 18.4495 & 15.5812 & 37.7431 \\
\hline 06XJ23-2 & -3.72 & 1430 & -0.44 & 6.88 & 1.28 & 6.044 & 19.371 & 15.598 & 39.246 & 18.442 & 15.5479 & 37.6729 \\
\hline 06XJ04 & 3.29 & 815 & -0.33 & & & & & & & & & \\
\hline 06XJ06 & 0.05 & 1080 & -0.32 & & & & & & & & & \\
\hline 06XJ010 & 0.00 & 1062 & -0.01 & 13.03 & 2.918 & 6.154 & 20.228 & 15.803 & 39.567 & 18.5689 & 15.7165 & 37.2233 \\
\hline 06XJ13 & -0.99 & 1143 & -0.14 & 15.27 & 2.375 & 9.799 & 19.562 & 15.758 & 39.632 & 18.7211 & 15.7142 & 37.9216 \\
\hline 06XJ15 & -1.72 & 1204 & -0.10 & & & & & & & & & \\
\hline
\end{tabular}

1400 
[First Authors Last Name] Page 64

1404 Appendix 5 Zircon Lu-Hf isotopic compositions for the porphyries from the Lamasu-Dabate area

\begin{tabular}{|c|c|c|c|c|c|c|c|c|c|}
\hline Spot & ${ }^{176} \mathrm{Yb} /{ }^{177} \mathrm{Hf}$ & ${ }^{176} \mathrm{Lu} /{ }^{177} \mathrm{Hf}$ & ${ }^{176} \mathrm{Hf} /{ }^{177} \mathrm{Hf}$ & $\pm 2 \sigma$ & $\mathrm{T}(\mathrm{Ma})$ & $(176 \mathrm{Hf} / 177 \mathrm{Hf}) \mathrm{i}$ & $\varepsilon \mathrm{Hf}(\mathrm{t})$ & $\mathrm{TDM}(\mathrm{Ga})$ & $f \mathrm{Lu} / \mathrm{Hf}$ \\
\hline \multicolumn{10}{|c|}{ Lamasu (06XJ17) } \\
\hline 06XJ17H1 & 0.04154 & 0.001737 & 0.282736 & 0.000027 & 364 & 0.282724558 & 6.3 & 0.75 & -0.95 \\
\hline $06 \mathrm{XJ} 17 \mathrm{H} 2$ & 0.03410 & 0.001428 & 0.282651 & 0.000029 & 366 & 0.282641163 & 3.4 & 0.86 & -0.96 \\
\hline 06XJ17H6 & 0.03806 & 0.001542 & 0.282733 & 0.000026 & 368 & 0.282722208 & 6.3 & 0.75 & -0.95 \\
\hline 06XJ17H7 & 0.05288 & 0.002157 & 0.282618 & 0.000024 & 364 & 0.282602845 & 2.0 & 0.93 & -0.94 \\
\hline $06 \mathrm{XJ} 17 \mathrm{H} 8$ & 0.05041 & 0.002018 & 0.282626 & 0.000032 & 366 & 0.282612212 & 2.4 & 0.91 & -0.94 \\
\hline 06XJ17H9 & 0.03963 & 0.001730 & 0.282666 & 0.000025 & 367 & 0.282654159 & 3.9 & 0.85 & -0.95 \\
\hline 06XJ17H10 & 0.08466 & 0.003326 & 0.282865 & 0.000037 & 370 & 0.282841811 & 10.6 & 0.58 & -0.90 \\
\hline 06XJ17H11 & 0.04498 & 0.001877 & 0.282789 & 0.000033 & 365 & 0.282775818 & 8.2 & 0.67 & -0.94 \\
\hline 06XJ17H12 & 0.04177 & 0.001737 & 0.282630 & 0.000021 & 368 & 0.282618308 & 2.7 & 0.90 & -0.95 \\
\hline 06XJ17H13 & 0.03805 & 0.001591 & 0.282598 & 0.000023 & 364 & 0.282587445 & 1.5 & 0.94 & -0.95 \\
\hline 06XJ17H15 & 0.03732 & 0.001575 & 0.282594 & 0.000023 & 367 & 0.28258342 & 1.4 & 0.95 & -0.95 \\
\hline 06XJ17H16 & 0.02806 & 0.001204 & 0.282631 & 0.000017 & 369 & 0.282622449 & 2.8 & 0.88 & -0.96 \\
\hline 06XJ17H18 & 0.04524 & 0.001906 & 0.282784 & 0.000028 & 362 & 0.282770779 & 7.9 & 0.68 & -0.94 \\
\hline 06XJ17H22 & 0.03707 & 0.001564 & 0.282613 & 0.000023 & 365 & 0.282601891 & 2.0 & 0.92 & -0.95 \\
\hline $06 \mathrm{XJ} 17 \mathrm{H} 23$ & 0.03221 & 0.001350 & 0.282633 & 0.000022 & 366 & 0.282623612 & 2.8 & 0.88 & -0.96 \\
\hline 06XJ17H5 & 0.02715 & 0.001152 & 0.282574 & 0.000025 & 405 & 0.282564837 & 1.6 & 0.96 & -0.97 \\
\hline 06XJ17H17 & 0.04366 & 0.001800 & 0.282606 & 0.000028 & 400 & 0.282592637 & 2.5 & 0.93 & -0.95 \\
\hline 06XJ17H24 & 0.03307 & 0.001275 & 0.282342 & 0.000020 & 907 & 0.282320586 & 4.1 & 1.29 & -0.96 \\
\hline 06XJ17H19 & 0.03502 & 0.001381 & 0.282279 & 0.000021 & 894 & 0.282255474 & 1.5 & 1.39 & -0.96 \\
\hline 06XJ17H20 & 0.03759 & 0.001540 & 0.282529 & 0.000026 & 738 & 0.282508092 & 7.0 & 1.04 & -0.95 \\
\hline 06XJ17H21 & 0.02583 & 0.001060 & 0.282411 & 0.000020 & 847 & 0.282393817 & 5.3 & 1.19 & -0.97 \\
\hline \multicolumn{10}{|l|}{ Dabate (06XJ13) } \\
\hline 06XJ13H2 & 0.06174 & 0.002198 & 0.282755 & 0.000026 & 291 & 0.282743366 & 5.4 & 0.73 & -0.93 \\
\hline 06XJ13H4 & 0.04701 & 0.001738 & 0.282751 & 0.000023 & 291 & 0.282741504 & 5.3 & 0.72 & -0.95 \\
\hline 06XJ13H5 & 0.02733 & 0.001081 & 0.282743 & 0.000021 & 291 & 0.282736778 & 5.2 & 0.72 & -0.97 \\
\hline $06 \mathrm{XJ} 13 \mathrm{H} 7$ & 0.03285 & 0.001225 & 0.282712 & 0.000024 & 290 & 0.282705175 & 4.0 & 0.77 & -0.96 \\
\hline 06XJ13H9 & 0.03537 & 0.001313 & 0.282773 & 0.000025 & 293 & 0.28276565 & 6.2 & 0.68 & -0.96 \\
\hline $06 \mathrm{XJ} 13 \mathrm{H} 10$ & 0.07640 & 0.002731 & 0.282730 & 0.000024 & 278 & 0.282715352 & 4.1 & 0.78 & -0.92 \\
\hline 06XJ13H12 & 0.03357 & 0.001331 & 0.282777 & 0.000026 & 291 & 0.282769521 & 6.3 & 0.68 & -0.96 \\
\hline 06XJ13H13 & 0.05890 & 0.002212 & 0.282704 & 0.000025 & 293 & 0.282691566 & 3.6 & 0.80 & -0.93 \\
\hline 06XJ13H15 & 0.03367 & 0.001349 & 0.282730 & 0.000022 & 294 & 0.282722835 & 4.7 & 0.75 & -0.96 \\
\hline 06XJ13H19 & 0.09805 & 0.003514 & 0.282732 & 0.000025 & 286 & 0.282712966 & 4.2 & 0.79 & -0.89 \\
\hline $06 \mathrm{XJ} 13 \mathrm{H} 20$ & 0.05437 & 0.001933 & 0.282779 & 0.000025 & 282 & 0.282768607 & 6.1 & 0.69 & -0.94 \\
\hline 06XJ13H22 & 0.04366 & 0.001703 & 0.282613 & 0.000022 & 294 & 0.282603968 & 0.5 & 0.92 & -0.95 \\
\hline $06 \mathrm{XJ} 13 \mathrm{H} 23$ & 0.05299 & 0.001977 & 0.282781 & 0.000025 & 291 & 0.282770158 & 6.3 & 0.69 & -0.94 \\
\hline $06 \mathrm{XJ} 13 \mathrm{H} 24$ & 0.04036 & 0.001489 & 0.282863 & 0.000039 & 288 & 0.282855456 & 9.3 & 0.56 & -0.96 \\
\hline $06 \mathrm{XJ} 13 \mathrm{H} 25$ & 0.06987 & 0.002334 & 0.282740 & 0.000039 & 287 & 0.282727885 & 4.8 & 0.75 & -0.93 \\
\hline 06XJ13H6 & 0.02555 & 0.001017 & 0.282681 & 0.000025 & 319 & 0.282675263 & 3.6 & 0.81 & -0.97 \\
\hline 06XJ13H18 & 0.06421 & 0.002400 & 0.282721 & 0.000030 & 319 & 0.282706231 & 4.7 & 0.78 & -0.93 \\
\hline 06XJ13H11 & 0.03908 & 0.001686 & 0.282915 & 0.000024 & 319 & 0.282904464 & 11.7 & 0.49 & -0.95 \\
\hline
\end{tabular}

